February 2000 - NREL/SR-540-27503

\title{
Development of the Next Generation Medium-Duty Natural Gas Engine
}

\section{Final Report}

\author{
D.J. Podnar and J.T. Kubesh \\ Southwest Research Institute \\ San Antonio, Texas
}

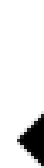

\section{NPEI}

National Renewable Energy Laboratory

1617 Cole Boulevard

Golden, Colorado 80401-3393

NREL is a U.S. Department of Energy Laboratory

Operated by Midwest Research Institute $\bullet$ Battelle $\bullet$ Bechtel

Contract No. DE-AC36-99-G010337 
February 2000 ・ NREL/SR-540-27503

\title{
Development of the Next Generation Medium-Duty Natural Gas Engine
}

\author{
Final Report
}

D.J. Podnar and J.T. Kubesh

Southwest Research Institute

San Antonio, Texas

NREL Technical Monitor: Keith Vertin

Prepared under Subcontract No. YCI-8-17074-01

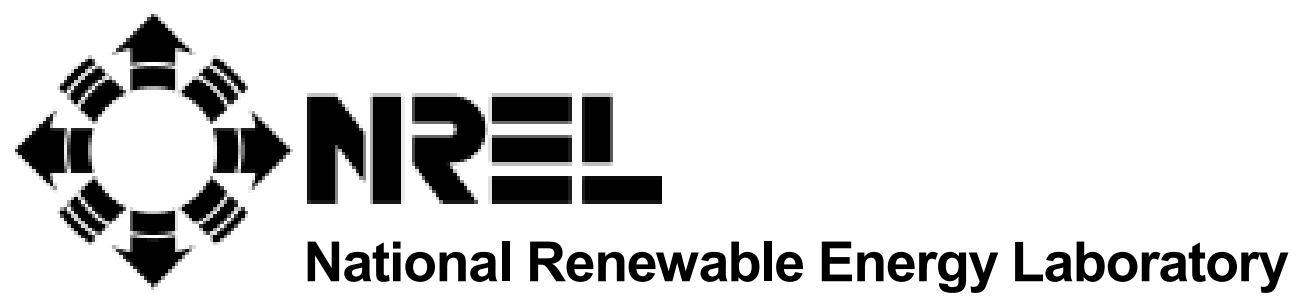

1617 Cole Boulevard

Golden, Colorado 80401-3393

NREL is a U.S. Department of Energy Laboratory

Operated by Midwest Research Institute • Battelle • Bechtel

Contract No. DE-AC36-99-G010337 
This publication was reproduced from the best available copy

Submitted by the subcontractor and received no editorial review at NREL

\section{NOTICE}

This report was prepared as an account of work sponsored by an agency of the United States government. Neither the United States government nor any agency thereof, nor any of their employees, makes any warranty, express or implied, or assumes any legal liability or responsibility for the accuracy, completeness, or usefulness of any information, apparatus, product, or process disclosed, or represents that its use would not infringe privately owned rights. Reference herein to any specific commercial product, process, or service by trade name, trademark, manufacturer, or otherwise does not necessarily constitute or imply its endorsement, recommendation, or favoring by the United States government or any agency thereof. The views and opinions of authors expressed herein do not necessarily state or reflect those of the United States government or any agency thereof.

Available electronically at http://www.doe.gov/bridge

Available for a processing fee to U.S. Department of Energy and its contractors, in paper, from:

U.S. Department of Energy

Office of Scientific and Technical Information

P.O. Box 62

Oak Ridge, TN 37831-0062

phone: 865.576 .8401

fax: 865.576.5728

email: reports@adonis.osti.gov

Available for sale to the public, in paper, from:

U.S. Department of Commerce

National Technical Information Service

5285 Port Royal Road

Springfield, VA 22161

phone: 800.553 .6847

fax: 703.605.6900

email: orders@ntis.fedworld.gov

online ordering: http://www.ntis.gov/ordering.htm 


\section{Executive Summary}

This report details work conducted under Southwest Research Institute (SwRI) Project 03-1374, "Development of the Next Generation Medium-Duty Natural Gas Engine." This project was sponsored by the National Renewable Energy Laboratory (NREL) under Subcontract Number YCI-8-17074-01. Under this subcontract, SwRI served as the prime contractor, with John Deere as a subcontractor. This report documents work conducted in the task areas of System Design, System Fabrication, and Experimental Program.

Details of the engine development process for achievement of throttleless stratified charge spark ignition (SI) engine operation as well as advanced turbocharging strategies are contained within this report. Engine test results showing the potential of the direct injection stratified charge combustion strategy for increasing part-load engine efficiency on a John Deere 8.1 liter natural gas engine are included in this report. In addition, steady-state and step transient engine data are presented which quantify the performance of a variable geometry turbocharger (VGT) as well as a modified wastegated turbocharger on the engine.

The benefits of the technologies investigated during this project are anticipated to be realized in the form of increased driving cycle efficiency to diesel-like levels while retaining the low emissions characteristics of a lean-burn natural gas engine. 


\section{Acknowledgement}

This research was sponsored by Stephen Goguen, Program Manager in the Department of Energy's Office of Heavy Vehicle Technologies. The technical monitor for this project was Keith Vertin, Senior Engineer at the National Renewable Energy Laboratory. 


\section{Table of Contents}

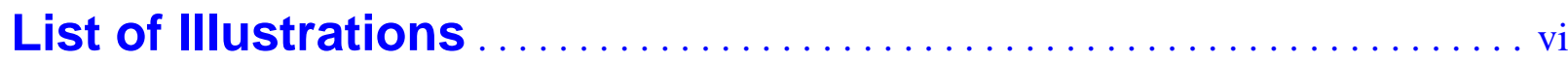

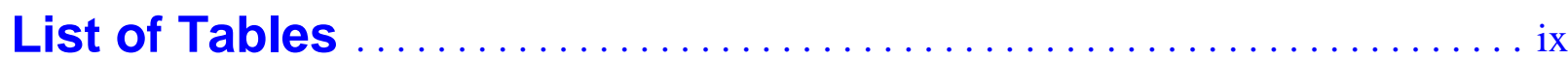

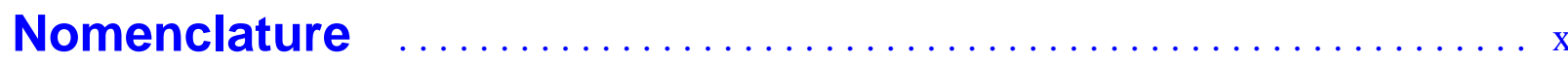

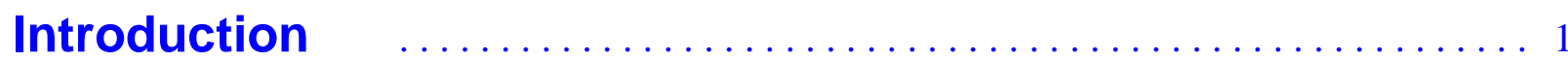

System Design/Fabrication ......................... 2

NREL School Bus Engine Baseline Measurements $\ldots \ldots \ldots \ldots \ldots 2$

Fuel Injection System Development $\ldots \ldots \ldots \ldots \ldots \ldots \ldots \ldots \ldots 4$

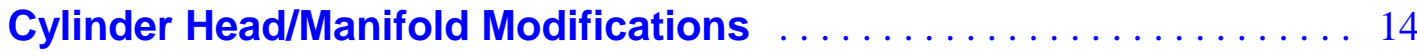

Engine Control System Development .................... 19

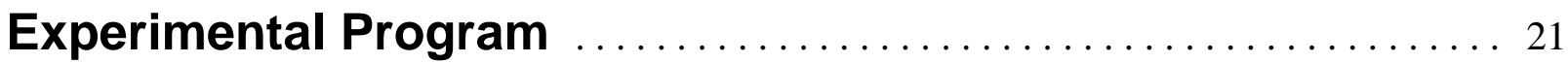

Cylinder Head Flow Bench Testing . . . . . . . . . . . . . . . 21

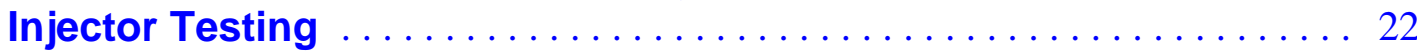

Combustion System Development Experiments ............. 23

Turbocharger Subsystem Experiments $\ldots \ldots \ldots \ldots \ldots \ldots \ldots \ldots . \ldots 1$

Other Activities ........................................ 55

Conclusions $\ldots \ldots \ldots \ldots \ldots \ldots \ldots \ldots \ldots \ldots \ldots \ldots \ldots \ldots \ldots \ldots \ldots \ldots \ldots$

Combustion System Conclusions $\ldots \ldots \ldots \ldots \ldots \ldots \ldots \ldots \ldots \ldots$

Turbocharger Subsystem Conclusions ................. 56

Recommendations for Future Study $\ldots \ldots \ldots \ldots \ldots \ldots \ldots \ldots$ 


\section{List of Illustrations}

Figure

Page

1 Thermal efficiency map for NREL ultra low emissions 8.1L John Deere Engine . . . . . 3

2 Predicted brake thermal efficiency $\ldots \ldots \ldots \ldots \ldots \ldots \ldots \ldots \ldots \ldots \ldots \ldots$

3 Predicted air/fuel ratio (DISC, MBT timing, NA) $\ldots \ldots \ldots \ldots \ldots \ldots \ldots \ldots$

4 Predicted fuel injection mass (mg/inj), DISC, MBT timing, JD 8.1L engine $\ldots \ldots \ldots 7$

5 Time window available for injection (ms), 20-180 CAD for DISC, $80 \mathrm{CAD}$ for $\mathrm{PI} / \mathrm{DI}$ homo. charge $\ldots \ldots \ldots \ldots \ldots \ldots \ldots \ldots \ldots \ldots \ldots \ldots$

6 Injection pressure requirements, DISC engine $\ldots \ldots \ldots \ldots \ldots \ldots \ldots$

$7 \quad$ ProEngineer solid model of direct gas injector assembly $\ldots \ldots \ldots \ldots \ldots \ldots$

8 Photograph of completed gas injector assembly $\ldots \ldots \ldots \ldots \ldots \ldots \ldots \ldots \ldots$

9 Photograph of gas injector installed in cylinder head $\ldots \ldots \ldots \ldots \ldots \ldots \ldots$

10 Plot of pressures within gas injector for a 2-millisecond injection period . . . . . . . 12

11 Plot of equivalence ratio as a function of axial and radial distances within a jet generated from a $1.22 \mathrm{~mm}(0.048 \mathrm{inch})$ orifice $\ldots \ldots \ldots \ldots \ldots \ldots \ldots$

12 Plot of equivalence ratio as a function of axial and radial distances within a jet generated from a $0.50 \mathrm{~mm}(0.20 \mathrm{inch})$ orifice $\ldots \ldots \ldots \ldots \ldots \ldots \ldots \ldots$

13 Photograph of intake port divider for isolation of test cylinder $\ldots \ldots \ldots \ldots \ldots$

14 Side view of modified cylinder head showing split intake and exhaust systems $\ldots \ldots 15$

15 Split intake runner assembly with mass air flow sensor $\ldots \ldots \ldots \ldots \ldots \ldots \ldots$

16 Photograph of injector nozzle and igniter plug locations in combustion chamber ... 16

17 Photograph of holes machined to accept igniter plug tube $\ldots \ldots \ldots \ldots \ldots$

18 ProEngineer solid model of igniter plug adapter tube $\ldots \ldots \ldots \ldots \ldots \ldots \ldots \ldots$

19 Photograph of completed igniter plug tube and coil-mounting sleeve $\ldots \ldots \ldots \ldots$ 


\section{List of Illustrations (Cont'd.)}

$\underline{\text { Figure }}$

Page

20 Coil-on-plug assembly $\ldots \ldots \ldots \ldots \ldots \ldots \ldots \ldots \ldots \ldots \ldots \ldots \ldots \ldots \ldots \ldots \ldots \ldots$

21 Photograph of coil-on-plug assembly installed in cylinder head $\ldots \ldots \ldots \ldots \ldots \ldots$

22 Plot of swirl testing results for cylinder head used in experimental program $\ldots \ldots 21$

23 Mold of maximum swirl intake port profile $\ldots \ldots \ldots \ldots \ldots \ldots \ldots \ldots \ldots \ldots$

24 Modified engine used for stratified charge combustion tests $\ldots \ldots \ldots \ldots \ldots \ldots$

25 Enlarged photograph of three-hole injector nozzle $\ldots \ldots \ldots \ldots \ldots \ldots \ldots \ldots \ldots$

26 Enlarged photograph of five-hole injector nozzle $\ldots \ldots \ldots \ldots \ldots \ldots \ldots \ldots \ldots$

27 IMEP as a function of A/F ratio for stratified charge operation at 1200 RPM $\ldots \ldots \ldots 26$

28 Cylinder pressure record for stratified charge operation $\ldots \ldots \ldots \ldots \ldots \ldots \ldots$

$29 \mathrm{HC}$ analyzer and sampling apparatus $\ldots \ldots \ldots \ldots \ldots \ldots \ldots \ldots \ldots \ldots \ldots$

30 Divided bowl combustion chamber piston $\ldots \ldots \ldots \ldots \ldots \ldots \ldots \ldots \ldots \ldots \ldots$

31 Divided bowl piston as installed in test engine $\ldots \ldots \ldots \ldots \ldots \ldots \ldots \ldots \ldots$

$32 \quad 6$-hole nozzle direct injector $\ldots \ldots \ldots \ldots \ldots \ldots \ldots \ldots \ldots \ldots \ldots \ldots \ldots \ldots \ldots \ldots$

33 9-hole nozzle for direct injector $\ldots \ldots \ldots \ldots \ldots \ldots \ldots \ldots \ldots \ldots \ldots \ldots \ldots \ldots \ldots$

34 Plot of IMEP and equivalence ratio for each test point $\ldots \ldots \ldots \ldots \ldots \ldots \ldots$

35 Indicated thermal efficiency versus indicated mean effective pressure for all data . . . 34

36 Combustion event timings for various spark timings and

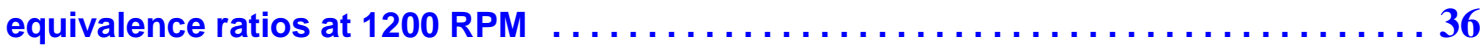

$37 \quad \mathrm{NO}_{\mathrm{x}}$ vs. $\mathrm{HC}$ tradeoff characteristic for the stratified charge engine.

Data obtained at test conditions defined in Table $2 \ldots \ldots \ldots \ldots \ldots \ldots \ldots$

38 Plot of ITE, misfire percentage, and $\mathrm{HC}$ emissions as a function of spark timing Data obtained at $1200 \mathrm{rpm}$, constant end of injection timing and equivalence ratio setpoints 


\section{List of Illustrations (Cont'd.)}

Figure

Page

$39 \quad$ Percentage of total fuel flow unburned and lost by the combustion chamber ..... 38

$40 \quad \mathrm{No}_{x}$ efficiency tradeoff as a function of injection pressure $\ldots \ldots \ldots \ldots \ldots \ldots \ldots$

$41 \quad$ Results of hybrid injection strategy testing $\ldots \ldots \ldots \ldots \ldots \ldots \ldots \ldots \ldots \ldots \ldots$

42 Modified wastegate actuator for enhanced wastegate evaluation $\ldots \ldots \ldots \ldots \ldots$

43 Variable geometry turbocharger $($ VNT40 $) \ldots \ldots \ldots \ldots \ldots \ldots \ldots \ldots \ldots \ldots$

44 Internal view of VNT40 variable nozzle vanes $\ldots \ldots \ldots \ldots \ldots \ldots \ldots \ldots \ldots \ldots$

45 Wastegate pneumatic control arrangement $\ldots \ldots \ldots \ldots \ldots \ldots \ldots \ldots \ldots \ldots \ldots$

$46 \quad$ VNT pneumatic control arrangement $\ldots \ldots \ldots \ldots \ldots \ldots \ldots \ldots \ldots \ldots \ldots$

$47 \quad$ Thermal efficiency map for enhanced wastegate engine $\ldots \ldots \ldots \ldots \ldots \ldots \ldots$

$48 \quad$ Thermal efficiency map for VNT engine $\ldots \ldots \ldots \ldots \ldots \ldots \ldots \ldots \ldots \ldots \ldots$

49 Cylinder head pressure differential map for enhanced wastegate engine $\ldots \ldots \ldots . .47$

50 Cylinder head pressure differential map for VNT40 engine $\ldots \ldots \ldots \ldots \ldots \ldots \ldots$

51 Throttle pressure differential map for enhanced wastegate engine . . . . . . . . 49

52 Throttle pressure differential for VNT engine $\ldots \ldots \ldots \ldots \ldots \ldots \ldots \ldots \ldots \ldots$

53 Wastegated turbocharger step transient with turbo lag compensation $\ldots \ldots \ldots \ldots 51$

54 Wastegated turbocharger step transient without turbo lag compensation $\ldots \ldots \ldots 52$

$55 \quad$ VNT40 step transient with turbo lag compensation $\ldots \ldots \ldots \ldots \ldots \ldots \ldots \ldots \ldots$

$56 \quad$ VNT40 step transient without turbo lag compensation $\ldots \ldots \ldots \ldots \ldots \ldots \ldots \ldots$ 


\section{List of Tables}

Table

Page

$1 \quad$ Speed and load data points $\ldots \ldots \ldots \ldots \ldots \ldots \ldots \ldots \ldots \ldots \ldots \ldots \ldots \ldots$

2 Test matrix for stratified charge combustion evaluation $\ldots \ldots \ldots \ldots \ldots \ldots \ldots$

3 Efficiency comparison between combustion modes at idle .............. 34

$4 \quad$ Boost response time comparison $-1350 \mathrm{rpm} \ldots \ldots \ldots \ldots \ldots \ldots \ldots \ldots \ldots \ldots$

$5 \quad$ Boost response time comparison $-1600 \mathrm{rpm} \ldots \ldots \ldots \ldots \ldots \ldots \ldots \ldots \ldots$

6 Boost response time comparison $-1900 \mathrm{rpm} \ldots \ldots \ldots \ldots \ldots \ldots \ldots \ldots \ldots$ 


\section{Nomenclature}

\section{Abbreviation}

BTDC

CAD

$\mathrm{COV}$

DI

DISC

IMEP

ISHC

ISNOx

ITE

JD

MBT

$\mathrm{ms}$

NA

PI

VGT

VNT

\section{Definition}

Before Top Dead Center

Crank Angle Degrees

Coefficient of Variation

Direct Injection

Direct Injection, Stratified Charge

Indicated Mean Effective Pressure

Indicated Specific Hydrocarbon Emission

Indicated Specific Nitrogen Oxide Emissions

Indicated Thermal Efficiency

John Deere

Minimum Spark Advance for Best Torque

Milliseconds

Naturally Aspirated

Port Injection

Variable Geometry Turbocharger

Variable Nozzle Turbine 


\section{Introduction}

The goal of this project was to increase the part-load fuel efficiency of a medium-duty natural gas engine to the same level as that of a state-of-the-art diesel engine, while retaining the emissions benefits of a current state-of-the-art natural gas engine.

The current state-of-the-art in medium-duty natural gas engines is represented by an engine developed on a NREL-sponsored program at SwRI. This effort developed a John Deere 8.1L natural gas engine capable of producing $275 \mathrm{HP}$ at $2200 \mathrm{RPM}$ and $250 \mathrm{psi}$ BMEP at $1300 \mathrm{RPM}$. The engine has achieved 40 percent brake thermal efficiency (\% LHV) at torque peak and 37 percent efficiency at rated power. Part load fuel economy was also superior to existing engines. This engine also had outstanding emissions performance, with $\mathrm{NO}_{\mathrm{x}}$ emissions averaging $1.0 \mathrm{~g} / \mathrm{bhp}$-hr over the U.S. EPA FTP transient test cycles. This combination of engine performance, efficiency, and emissions defines the current state-of-the-art in medium-duty alternative fueled engines.

However, current state-of-the-art natural gas engines do suffer significant efficiency reductions at part load and small reductions at full load from their diesel counterparts. These efficiency reductions can be attributed to two primary factors, reduction in compression ratio and throttling losses. These factors greatly influence vehicle fuel economy and hence, vehicle operating cost and range. This is a primary obstacle in achieving widespread commercial acceptance of alternative fueled vehicles and is, therefore, the focus of the work discussed in this report.

The technology described herein was a radical departure from current lean burn SI engine technology. It was aimed at increasing part load efficiency by reduction or elimination of throttling losses. The engine was modified to use a direct fuel injection strategy to create a stratified fuel-air charge capable of combustion at overall air-fuel ratios higher than the lean limit air-fuel ratio characteristic of homogenous mixtures. This stratified charge technique, along with associated control strategies, is intended to allow throttleless part load operation. Use of a variable geometry turbocharger (VGT) for efficient load modulation and improved transient response was also investigated. 


\section{System Design/Fabrication}

The purpose of the System Design and System Fabrication tasks was to develop the engine, fuel metering system, and the turbocharger hardware needed for testing during the Experimental Program. Both the System Design and System Fabrication tasks were essentially divided into two parts with separate design and fabrication requirements for each. The first part involved those tasks needed to develop the direct injection stratified charge (DISC) combustion system. This involved modification of engine hardware such as the cylinder head, intake manifold, and exhaust manifold. In addition, new hardware was designed and fabricated for the purpose of implementing the DISC system. The second portion of the System Design and System Fabrication tasks involved the development of hardware modifications needed to perform the enhanced wastegate and variable geometry turbocharger (VGT) evaluations. In this part of the project, the engine was returned essentially to a production configuration with the exception of the turbocharger hardware and the engine control system. As such, the design and fabrication tasks described within this section of the report are focused upon the DISC engine configuration. Although a small amount of design and fabrication work was required in the turbocharger investigation, it was felt that the details of this work were more appropriately discussed within the Experimental Program section of this report. Details of the system design and fabrication process are contained in the following paragraphs.

\section{NREL School Bus Engine Baseline Measurements}

In order to develop a basis for quantifying the performance of the new engine concept, baseline efficiency and emissions data were obtained from the ultra low emissions (ULE) engine developed during the NREL school bus project. These data established the ground work from which the results of this project would be compared. This task was essentially a precursor to the System Design task. For purposes of this report however, the baseline data are included within the System Design and Fabrication section. These data are to be used for comparison with similar data to be obtained during Phase II of the current project. The ULE engine was used as the baseline since this engine is considered to be the state of the art in terms of engine efficiency and emissions. Furthermore, it is likely that future production Deere gas engines will have performance characteristics similar to this engine. Efficiency improvements relative to the baseline results will be considered an advancement in the state of the art.

The engine was performance mapped over the entire operating range. Table 1 lists the speed and load data points that were collected. At each point, the performance data such as speed, torque, air flow, fuel flow, and relevant temperatures and pressures were collected. These data were used to calculate brake horsepower, brake thermal efficiency, volumetric efficiency, and other performance parameters. Fifty cycles of crankangle-resolved cylinder pressure data were also collected and statistically analyzed to provide average peak cylinder pressures, combustion burn intervals, and indicated horsepower. Measurements of gaseous exhaust emissions, including $\mathrm{NO}_{x}, \mathrm{CO}, \mathrm{HC}, \mathrm{CO}_{2}$, and $\mathrm{O}_{2}$, were made at each point, and the fuel-air equivalence ratio and brake specific emissions were calculated from these data.

A map of thermal efficiency for the ULE engine is shown in Figure 1. The map shows contours of constant thermal efficiency as a function of speed and load. The map plainly shows the decrease in thermal efficiency as load decreases. Interesting to note, however, is the fact that the engine maintains an efficiency of nearly 35 percent down to a load of approximately $350 \mathrm{ft}-\mathrm{lbs}$. The efficiency drops rapidly as the load is decreased below $350 \mathrm{ft}-\mathrm{lbs}$, which is the region where throttling must be used to reduce load. Use of a throttleless or reduced throttling scheme in this region was expected to provide a noticeable increase in efficiency. 
Table 1. Speed and load data points

\begin{tabular}{||c|c|c|c|c|c|c||}
\hline $\begin{array}{c}\text { Speed } \\
\text { (rpm) }\end{array}$ & \multicolumn{6}{|c|}{ Load } \\
\hline \hline & Min. & $10 \%$ & $25 \%$ & $50 \%$ & $75 \%$ & $100 \%$ \\
\hline 650 & $\mathrm{X}$ & $\mathrm{X}$ & $\mathrm{X}$ & $\mathrm{X}$ & $\mathrm{X}$ & $\mathrm{X}$ \\
\hline 800 & & $\mathrm{X}$ & $\mathrm{X}$ & $\mathrm{X}$ & $\mathrm{X}$ & $\mathrm{X}$ \\
\hline 1000 & $\mathrm{X}$ & & $\mathrm{X}$ & $\mathrm{X}$ & $\mathrm{X}$ & $\mathrm{X}$ \\
\hline 1200 & & $\mathrm{X}$ & $\mathrm{X}$ & $\mathrm{X}$ & $\mathrm{X}$ & $\mathrm{X}$ \\
\hline 1350 & & & & & & $\mathrm{X}$ \\
\hline 1400 & & $\mathrm{X}$ & $\mathrm{X}$ & $\mathrm{X}$ & $\mathrm{X}$ & $\mathrm{X}$ \\
\hline 1600 & $\mathrm{X}$ & & $\mathrm{X}$ & $\mathrm{X}$ & $\mathrm{X}$ & $\mathrm{X}$ \\
\hline 1800 & $\mathrm{X}$ & & $\mathrm{X}$ & $\mathrm{X}$ & $\mathrm{X}$ & $\mathrm{X}$ \\
\hline 2000 & $\mathrm{X}$ & & $\mathrm{X}$ & $\mathrm{X}$ & $\mathrm{X}$ & $\mathrm{X}$ \\
\hline 2200 & $\mathrm{X}$ & & $\mathrm{X}$ & $\mathrm{X}$ & $\mathrm{X}$ & $\mathrm{X}$ \\
\hline \hline
\end{tabular}

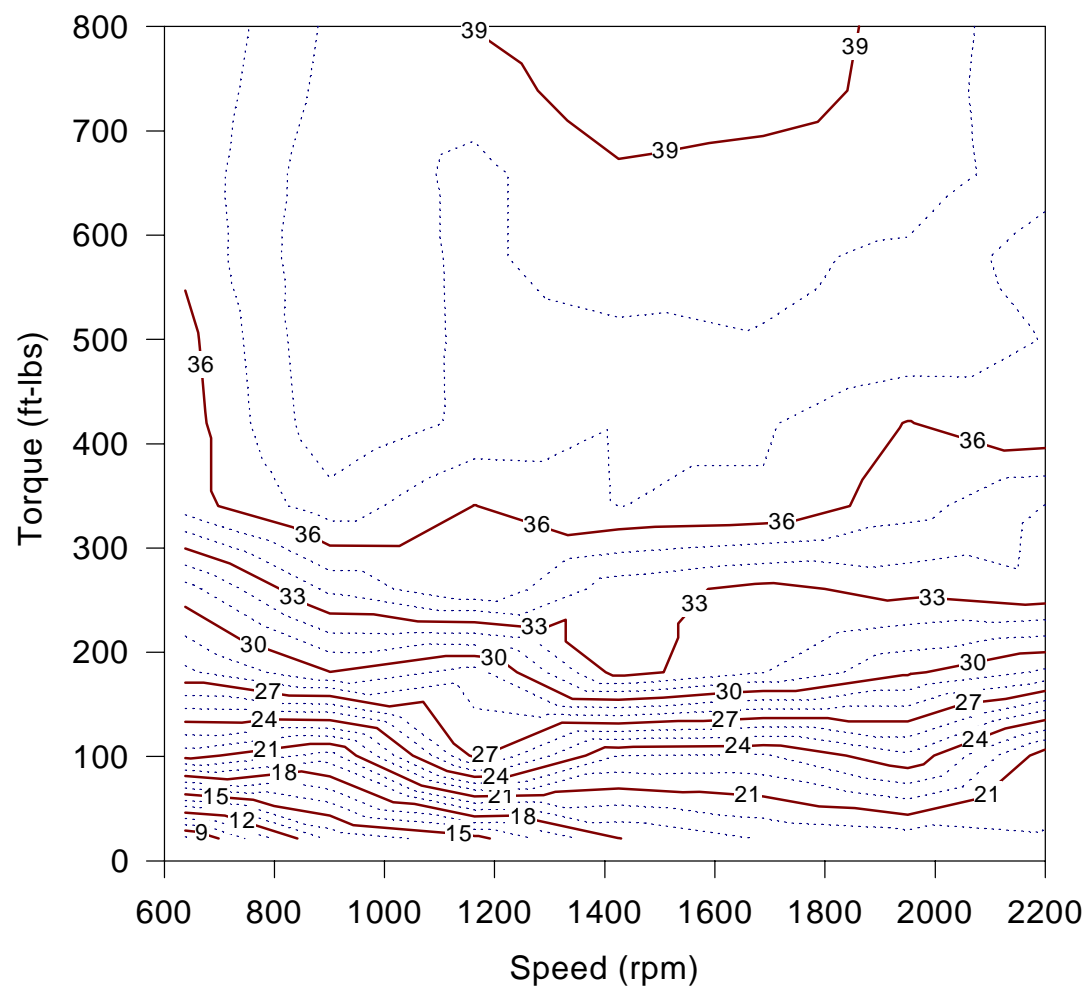

Figure 1. Thermal efficiency map for NREL ultra low emissions 8.1L John Deere engine (Lines of constant brake thermal efficiency in percent) 


\section{Fuel Injection System Development}

In order to accommodate the development of the combustion strategies for the project, three fuel injection systems were originally planned for evaluation on the engine: direct injection, port injection, and single point premixed injection. Since the production Deere 8.1L engine is operated in a single point premixed injection mode, very little fuel injection system development was required for this injection system. Furthermore, although port injection was possible with the production injection hardware, it was felt that the injector sizing requirements for the direct injector and port injector could be made identical. Ultimately, the port injection configuration was not used on the engine, since the necessary levels of stratification were felt to be unachievable using port injection. Therefore, the focus of the fuel injection system development effort was in development of a direct fuel injection system for the engine. The details of the development process are contained in the following paragraphs.

\section{Direct Injection System Analysis}

An analysis of the fuel injection system requirements for direct injection (DI) and port injection (PI) was conducted. A cycle simulation model, developed by SwRI, was utilized to predict the thermal efficiency and air-fuel $(\mathrm{A} / \mathrm{F})$ ratio for the engine at various operating conditions utilizing an unthrottled configuration. These data are shown as a function of engine speed and torque in Figures 2 and 3, respectively. From this data, along with airflow predictions from the simulation, the required fueling [in milligrams (mg) per injection event] was computed. These data are shown in Figure 4. In order to inject this fuel within a time window defined by 20 crank-angle degrees at minimum load to 180 crank-angle degrees at roughly the $300 \mathrm{ft}-\mathrm{lb}$ torque level and above, the available time window in milliseconds ( $\mathrm{msec}$ ) was computed. These data are shown in Figure 5 and represent a maximum amount of time, which is available for the fuel injection event to occur. These data, along with the fuel-injection mass data from Figure 4, at high speed and high load conditions, define the minimum sizing of the injection system in terms of fuel mass per millisecond of fuel pulse width. The maximum sizing of the injection hardware is determined by the turndown ratio needed in order to achieve light load or idle operation. Given that the minimum injection pulse width at which the fastest injectors could accurately meter fuel is roughly $1 \mathrm{msec}$, and the minimum fuel mass per injection is roughly $10 \mathrm{mg}$, an injector sized for roughly $7.5 \mathrm{mg} / \mathrm{msec}$ was chosen. This should provide adequate margin and turn down at idle conditions while still providing adequate fuel metering capacity to easily achieve the full-load torque curve for the engine. 


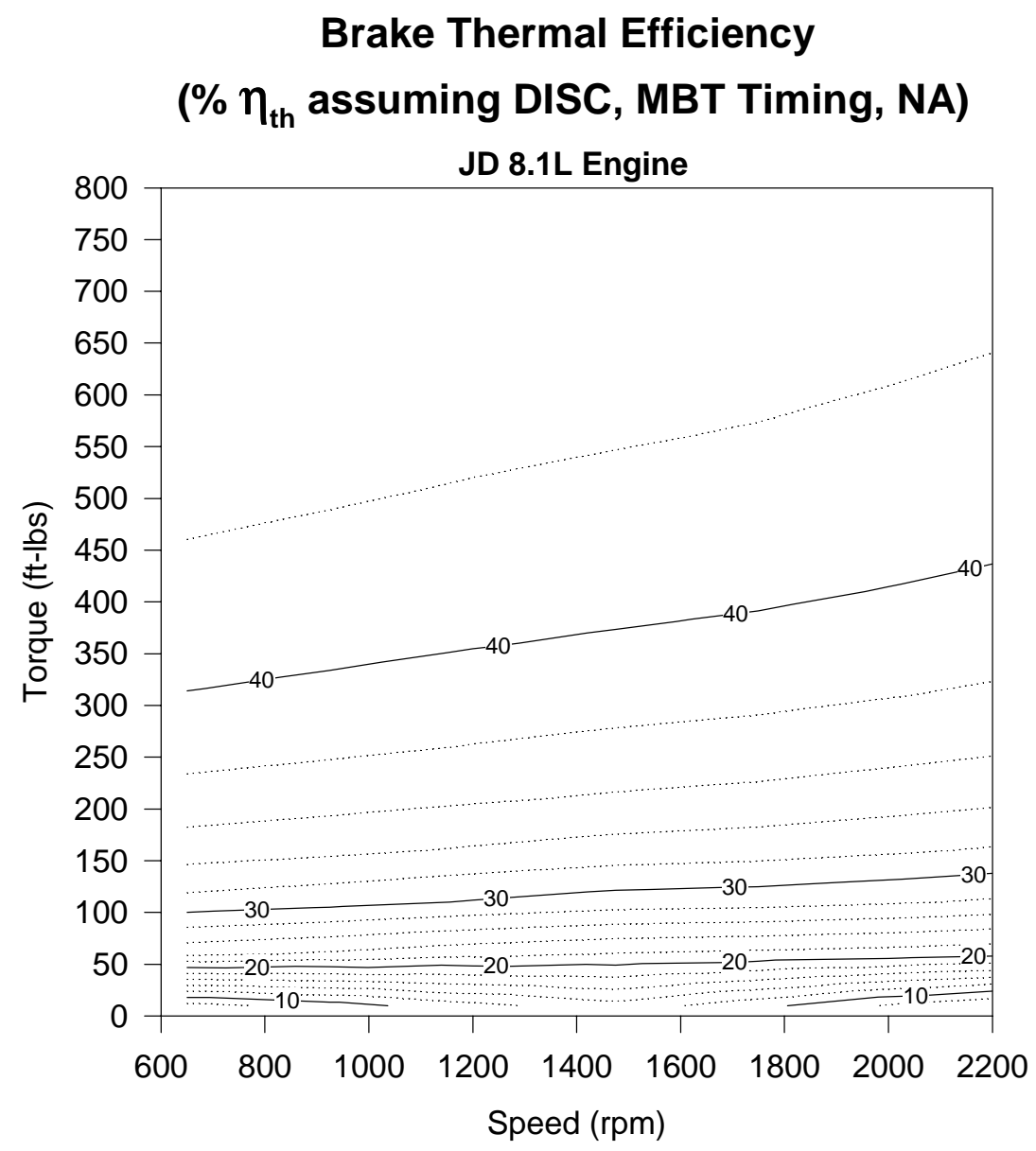

Figure 2. Predicted brake thermal efficiency 


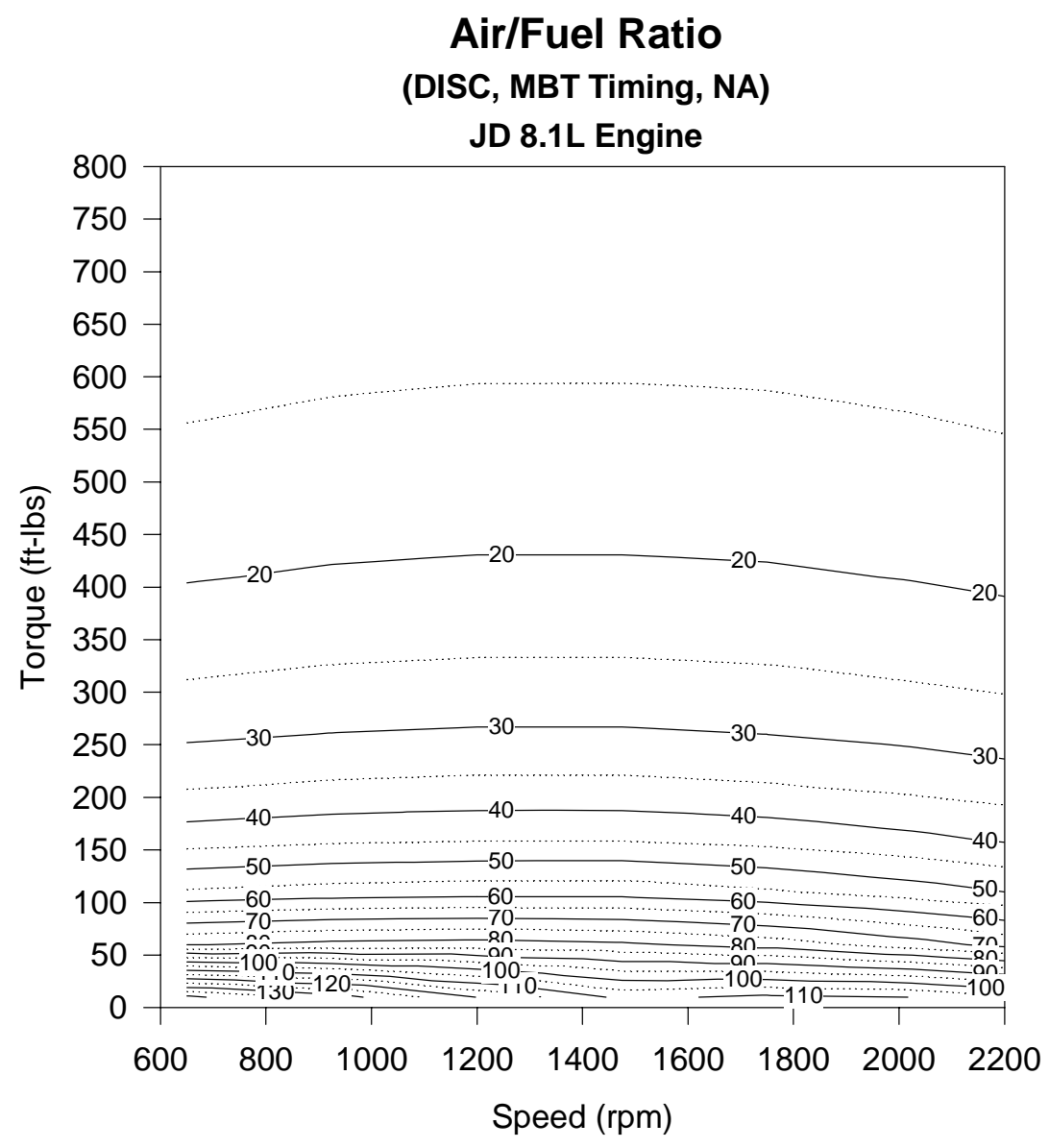

Figure 3. Predicted air/fuel ratio (DISC, MBT timing, NA) 


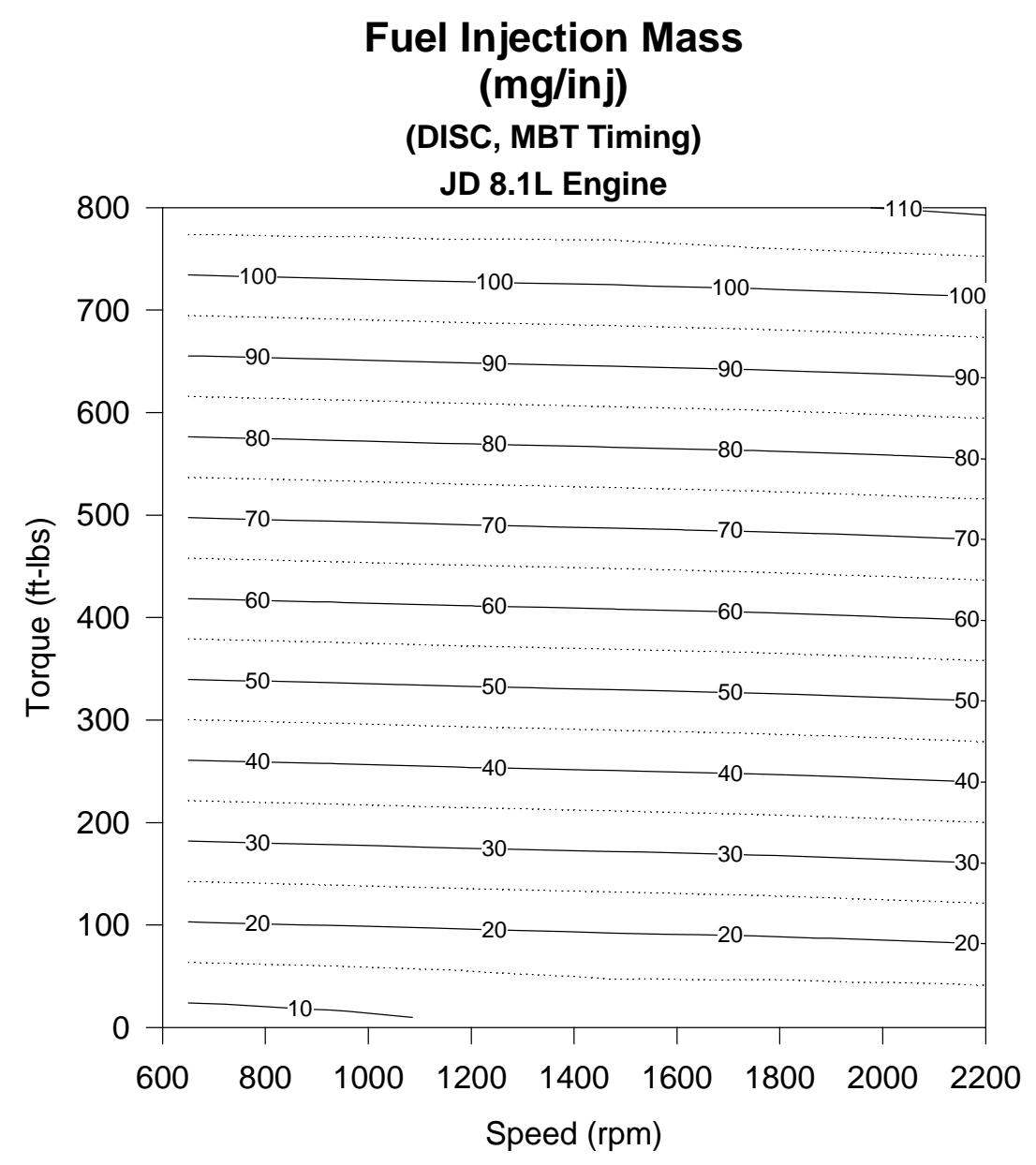

Figure 4. Predicted fuel injection mass (mg/inj), DISC, MBT timing, JD 8.1L engine 


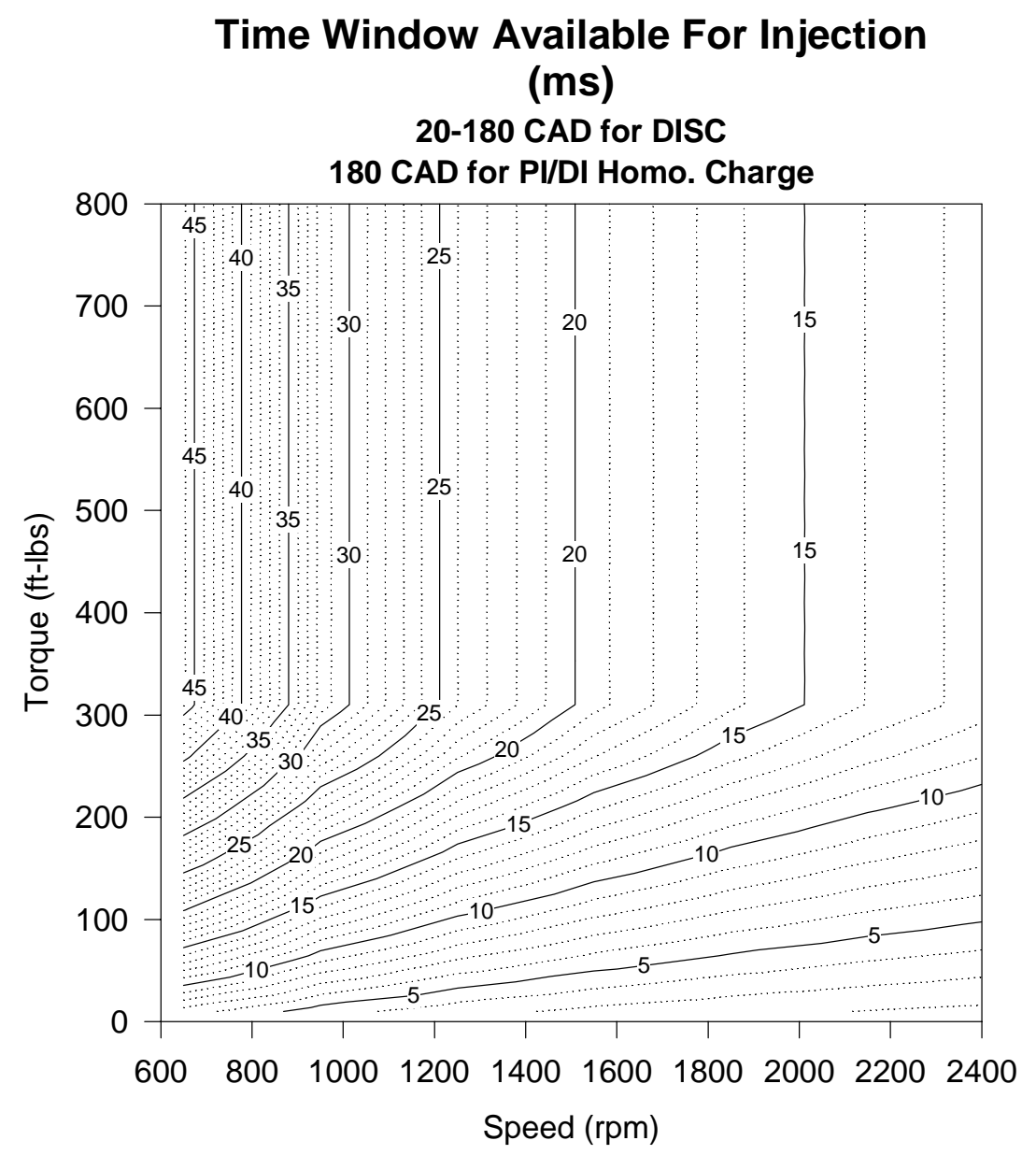

Figure 5. Time window available for injection (ms), 20-180 CAD for DISC, 180 CAD for PI/DI homo. charge 
An analysis to determine the necessary fuel supply pressure to the injection system was also conducted. Since it was understood that the maximum fuel supply pressure requirements would be for the direct injection fuel system, it was decided that a single injection system designed for these conditions would be used for both the DI and PI systems. Knowing that the fuel injectors are designed to operate under choked flow conditions across the metering orifice, the minimum fuel supply pressure needed to maintain choked flow during the entire injection event was chosen as the target supply pressure for the design of the injectors. Figure 6 shows the cylinder pressure profile for an unthrottled motoring condition, along with the pressure needed in order to maintain choked flow (of methane), as a function of crank angle. Since the most retarded spark timing values used for the engine are roughly 12-degrees BTDC at idle conditions, and assuming that the fuel injection event must end at least 3 crank-angle degrees prior to the spark event, it was determined that a supply pressure of 500 psig would be adequate for the DI and PI fuel systems. This is labeled on Figure 6 as Max. Pressure Available.

\section{Injection Pressure Requirements DISC Engine}

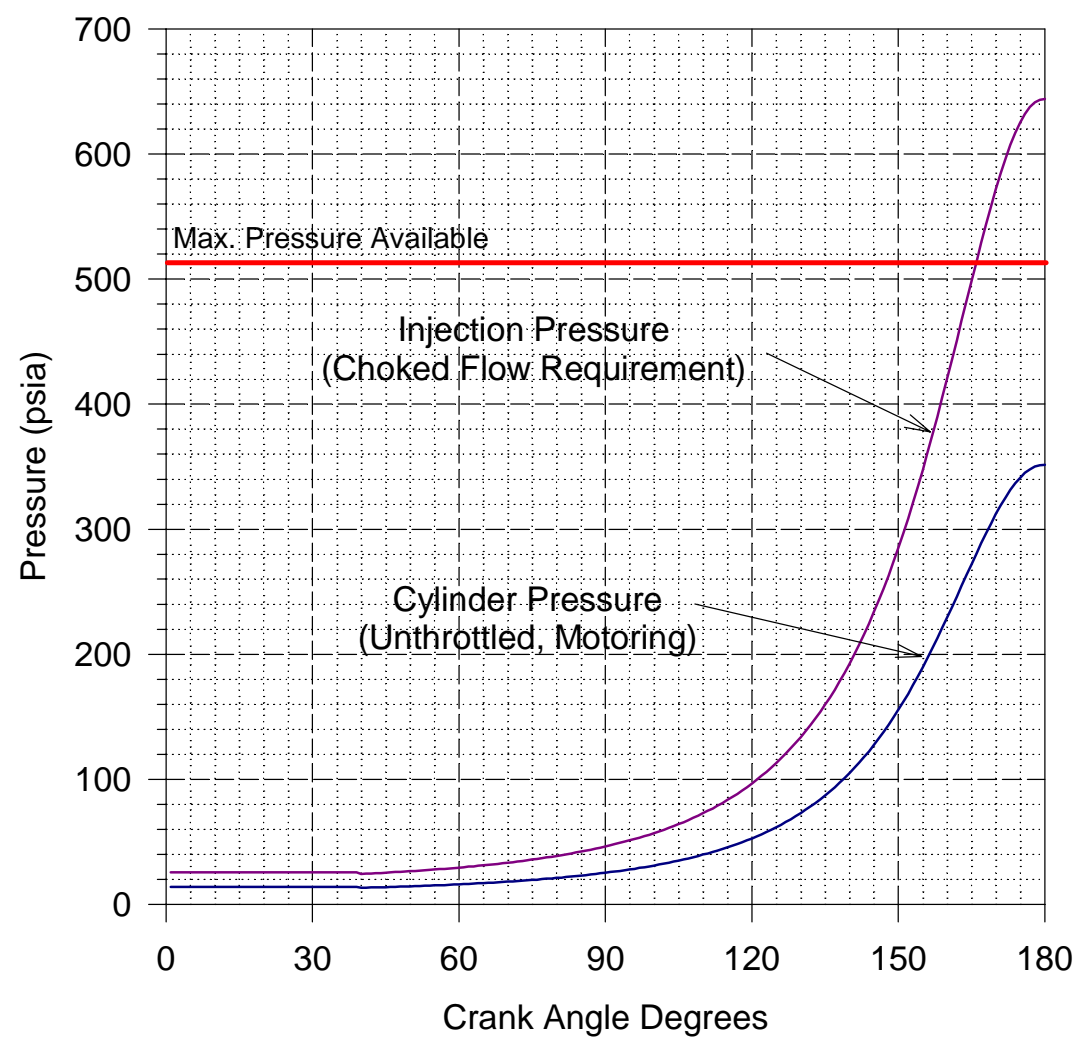

Figure 6. Injection pressure requirements, DISC engine 


\section{Direct Injection System Hardware Suppliers}

SwRI attempted to contact three potential suppliers for development of prototype fuel injection hardware to meet SwRI specifications. The two suppliers, responded to SwRI's inquiries. The first supplier, Sturman Industries of Woodland Park, Colorado, had developed natural gas fuel injectors capable of operating at increased supply pressures, with sizing roughly suitable for this application. A second supplier, Clean Air Partners (CAP) of San Diego, California, also had developed natural gas fuel injectors which were capable of adaptation to the direct injection application. Prototype injectors from Sturman Industries and production injectors from CAP were delivered and tested at SwRI. The production Servojet injectors from CAP were ultimately used for all engine testing. More details on the testing of the injectors is contained in the chapter entitled, "Experimental Program" in the section "Injector Testing."

\section{Direct Injector Design}

The basis of the direct injector design for the project was a prechamber fuel metering system for a prechamber natural gas engine. SwRI has had a great deal of success in developing precise fuel metering systems for prechambers using automotive fuel injection technology, so this method was expanded for use in a direct injection environment. The fuel injection system uses a fuel metering element, typically an automotive gaseous fuel injector, and a check valve that is used to isolate the metering element from combustion pressure and gases. These elements were incorporated into an injector assembly along with a multihole nozzle to direct the fuel gas into the combustion chamber.

Figure 7 shows a ProEngineer solid model of the injector assembly. The injector assembly is composed of several parts: an adapter for mounting the injector in the 14-mm spark plug hole, a nozzle, the injector body containing the check valve, and the metering unit. The injector is held in the adapter underneath a threaded jam nut. The nozzle is readily positionable and replaceable since it is attached to the injector body by a threaded sleeve. The metering unit contains the Sturman DGI injector along with temperature and pressure sensors for the calculation of fuel density. A separate metering unit was designed for use with the Servojet fuel injector. Each of the metering units was designed to be interchangeable with the remaining injector hardware. The metering units could be disassembled from the injector via a compression fitting between the two pieces. A photograph of the fabricated injector is shown in Figure 8, and Figure 9 is a photograph of the injector mounted in the cylinder head.

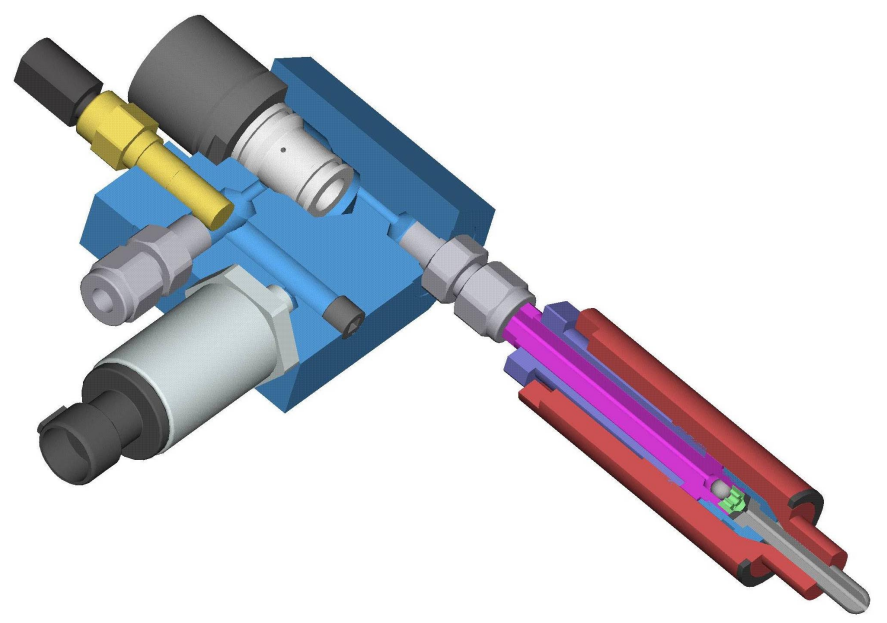

Figure 7. ProEngineer solid model of direct gas injector assembly 


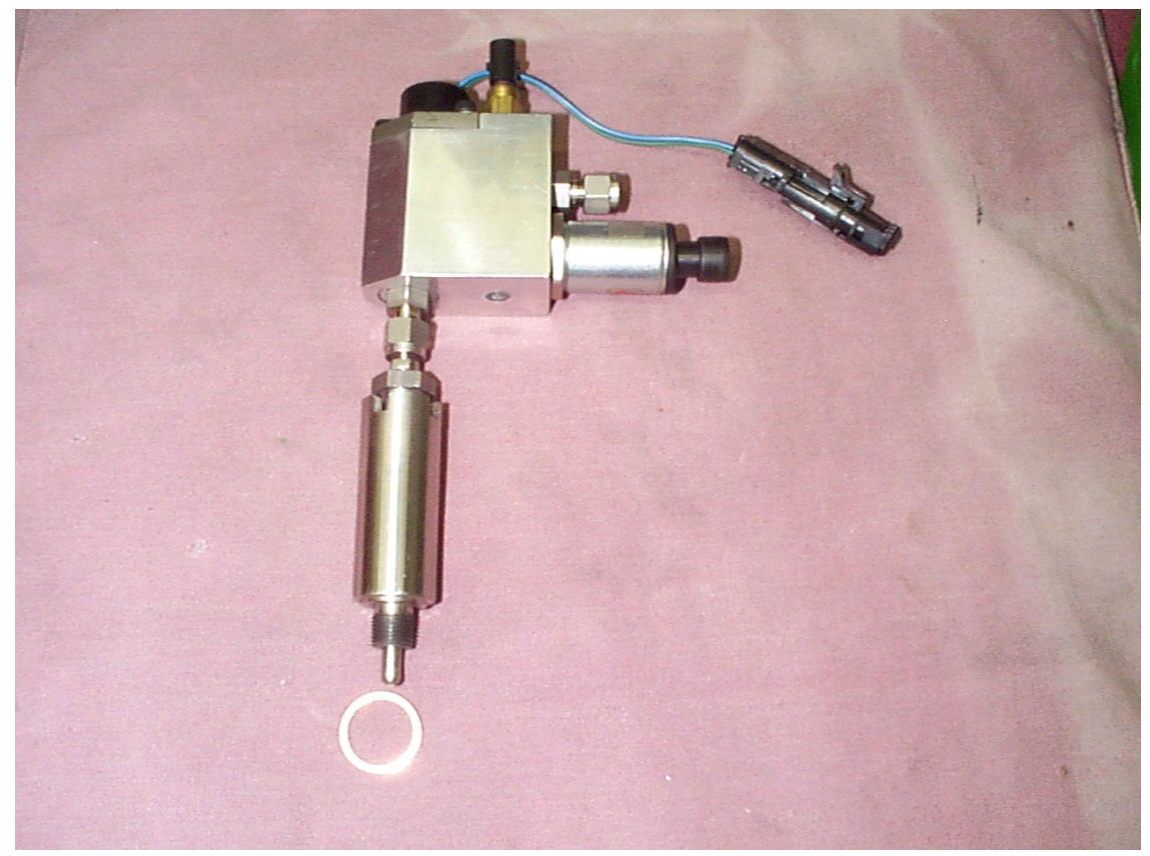

Figure 8. Photograph of completed gas injector assembly

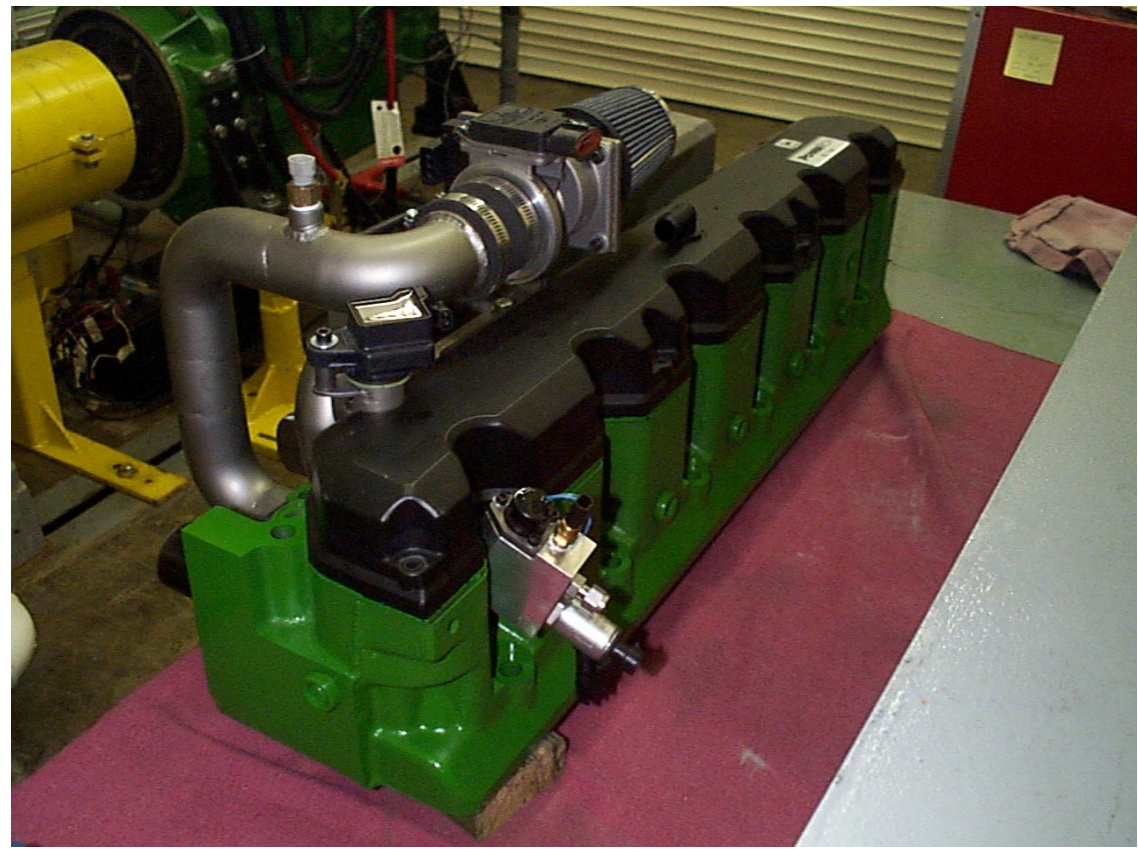

Figure 9. Photograph of gas injector installed in cylinder head

Design of the injector and nozzle were aided by two computer models, JETMIX and INJFLOW. INJFLOW was used to analyze the flow and restrictions within the injector, and JETMIX was used to analyze the injection flow pattern obtained from the injector nozzle. 
The INJFLOW model was developed specifically for this project. It is a one-dimensional model of flow through the injector. The injector is represented by a series of volumes and orifices. Flow through the orifices is calculated through the use of compressible flow equations. Both sonic (choked) and subsonic (unchoked) flow calculations are used depending on the pressure ratio across each orifice. Flow through the orifices are used in a filling/emptying model for each injector volume, which simulates the transient response of the injector. The model requires the internal measurements of the injector for calculating volumes. Boundary and initial conditions are set by the gas supply pressure and the injector nozzle discharge (cylinder) pressure. An example of the output data from the model is plotted in Figure 10. This plot shows pressures at various locations within the injector throughout the injection event. In this example, the supply pressure was assumed constant at $500 \mathrm{psia}(3.45 \mathrm{MPa})$, and the nozzle discharge or cylinder pressure was assumed constant at $240 \mathrm{psia}(1.65 \mathrm{MPa})$. The injector response is quite fast, with nearly full injection pressure reached within 1 millisecond. Also, the pressure at the end of injection drops off quickly so that the injection event is sharply defined.

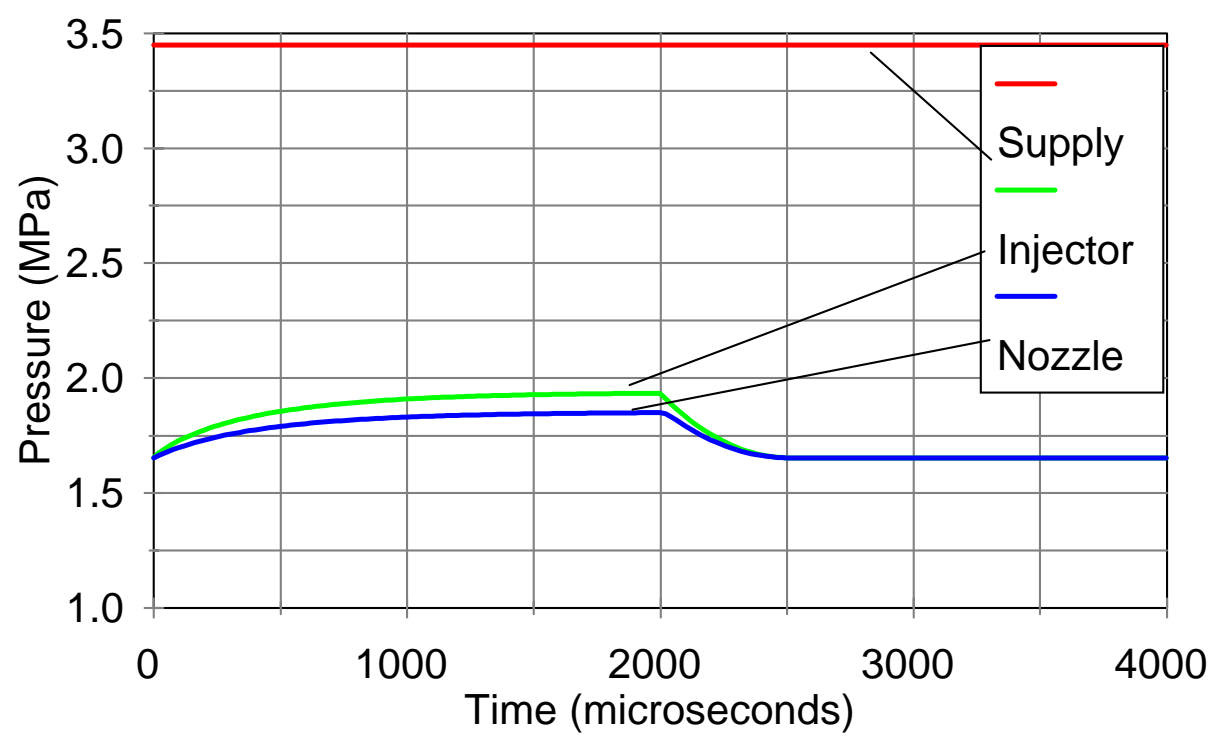

Figure 10. Plot of pressures within gas injector for a 2-millisecond injection period

INJFLOW was used to determine the equivalent orifice diameter for the nozzle holes and the effective injection pressure upstream of the nozzle holes. Both of these numbers are required as initial conditions in the JETMIX model. The model also can calculate the mass of fuel metered per injection event and whether or not the metering orifice (within the Sturman or CAP injector) is choked. Maintaining choked flow across the metering orifice is important for fuel metering accuracy.

Using nominal injector dimensions and a gas supply pressure of 500 psia, an equivalent nozzle orifice diameter of $2.44 \mathrm{~mm}$ (0.096 inch) was found to provide choked flow conditions at the metering orifice at nozzle discharge pressures up to $240 \mathrm{psia}$. This pressure corresponds to the cylinder pressure at approximately $18^{\circ}$ BTDC for a naturally-aspirated, unthrottled engine with a compression ratio of 11.3 operating at a speed of $2200 \mathrm{rpm}$. This point is roughly equivalent to the minimum spark timing for the engine across the operating map, so the injection process should remain repeatable prior to ignition by the spark plug. Use of a lower compression ratio or some limited throttling would allow choked injector operation closer to TDC. 
JETMIX is an analytical spray model that was developed by SwRI for the analysis of gasoline and diesel fuel injectors. The model is based on the calculation method outlined by Sinnamon, et al. in SAE Paper No. 800135, "An Experimental and Analytical Study of Engine Fuel Spray Trajectories." It consists of integral continuity and momentum equations that describe a steady-state gas jet. The gas-jet assumption makes JETMIX directly applicable to solving direct gas injection problems. JETMIX is a very useful tool for gas injector studies, since it allows easy variation of important injection parameters such as nozzle hole size, injection pressure, and others.

Results from JETMIX for two different nozzle sizes are shown below. The data are presented as a map of fuel-air equivalence ratio as a function of axial (x-distance) and radial (y-distance) from the nozzle hole exit. Equivalence ratios between 0.75 and 1.25 are plotted since this is the approximate range required for easy ignition of the fuel-air mixture. The first plot, Figure 11 , shows the results for a $1.22 \mathrm{~mm}(0.048 \mathrm{inch})$ orifice. Four orifices of this size would be required to provide the desired equivalent orifice diameter of $2.44 \mathrm{~mm}$ (0.096 inch). Orifices of this size would be relatively easy to machine, but they also present a problem. Examination of the equivalence ratio contours reveals a steep rise in equivalence ratio, and the flammable region is quite narrow. The fuel placement with nozzle holes of this size would be critical. An alternative design would be to use a three-hole nozzle, with one small [0.50 $\mathrm{mm}(0.020 \mathrm{inch})]$ hole aimed at the igniter plug and two larger [1.51 $\mathrm{mm}(0.066 \mathrm{inch})]$ holes that straddle either side of the igniter. The advantage to this approach can be seen in Figure 12. With this orifice size, the fuel spray has an equivalence ratio within the ignition limits over a wide range of axial and radial distances. This should allow some variability in the orientation of the injector nozzle.

Two nozzles, one with four $1.22 \mathrm{~mm}(0.048 \mathrm{inch})$ and one with one $0.50 \mathrm{~mm}(0.020$ inch $)$ holes and two $1.51 \mathrm{~mm}$ (0.066 inch) holes, were designed. The nozzles were tested as part of the Experimental Program task.

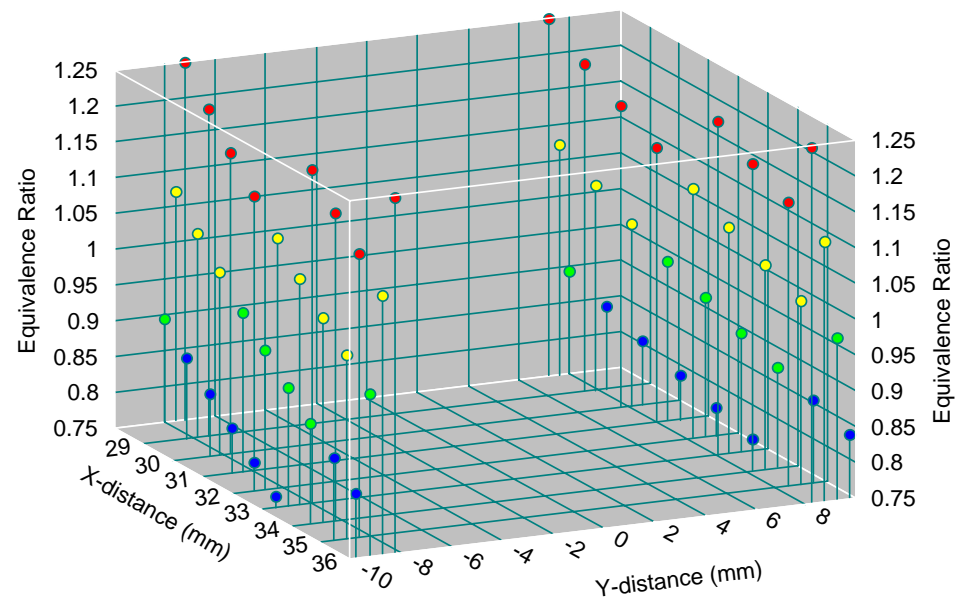

Figure 11. Plot of equivalence ratio as a function of axial and radial distances within a jet generated from a $1.22 \mathrm{~mm}$ (0.048 inch) orifice 


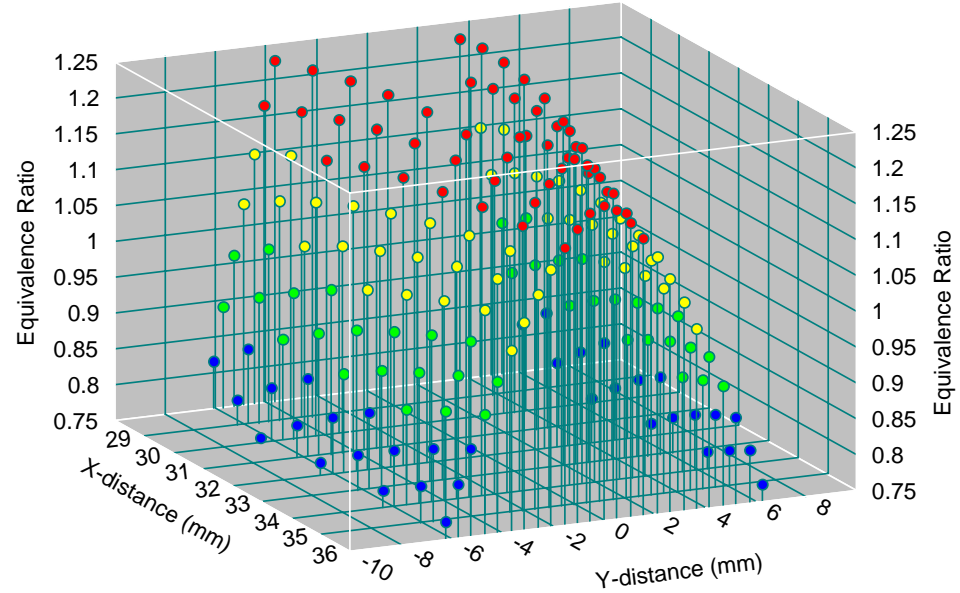

Figure 12. Plot of equivalence ratio as a function of axial and radial distances within a jet generated from a $0.50 \mathrm{~mm}(0.20 \mathrm{inch})$ orifice

\section{Cylinder Head/Manifold Modifications}

One of the first design tasks was to modify the engine so that one cylinder could be operated in a stratified charge mode. The John Deere 8.1L engine uses a siamese intake port cylinder head design. In order to isolate the test cylinder, the intake port for cylinders 5 and 6 were separated using a thin metal divider plate. The plate installed in the modified port is shown in Figure 13.

The intake and exhaust manifolds were also modified to handle the flows into and out of the test cylinder. Figure 14 is a side view of the complete cylinder head and manifold assembly with modifications. A view of the split intake runner system is shown in Figure 15. Note the mass air flow sensor installed in the test cylinder runner for measuring the air flow to that cylinder.

\section{Engine Modifications for Direct Injection System}

Initial combustion system design work focused on determining the location of the injector and the spark plug within the cylinder head. Due to space constraints, the direct injector was placed in the spark plug location, near the center of the combustion chamber. The spark plug was moved to the opposite side of the valves, approximately $32 \mathrm{~mm}$ from the injector nozzle, as shown in Figure 16, a close-up view of the modified combustion chamber that shows the relative positions of the spark plug and the injector nozzle. This required that an additional hole be machined into the head to locate the spark plug and adapter, as shown in Figure 17. A ProEngineer solid model of the spark plug tube is shown in Figure 18. This tube was designed to hold an igniter plug instead of the current spark plug. The production 14-mm spark plug would not fit between the valves, so the smaller diameter, unthreaded igniter plug was used. The igniter plug was held in place by a threaded jam nut. A photograph of the finished spark plug tube is shown in Figure 19. A coil-on-plug assembly, consisting of a Nippondenso inductive coil, a steel coil retainer, a teflon insulator, and a silicone rubber boot, was fabricated. This assembly with an igniter plug is shown in Figure 20. This assembly was held in place with a valve cover capscrew; the assembly as installed in the head is shown in Figure 21. 


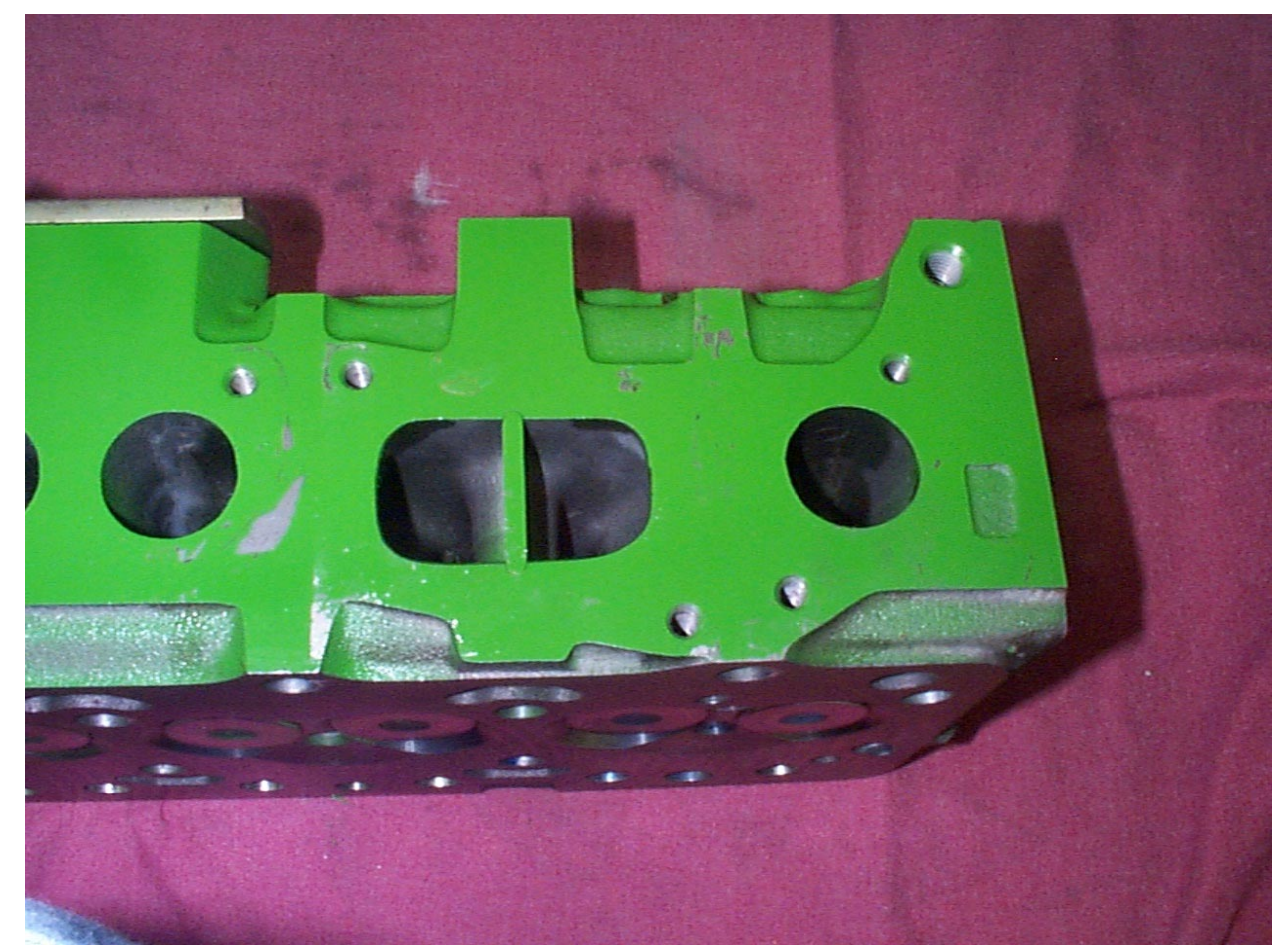

Figure 13. Photograph of intake port divider for isolation of test cylinder

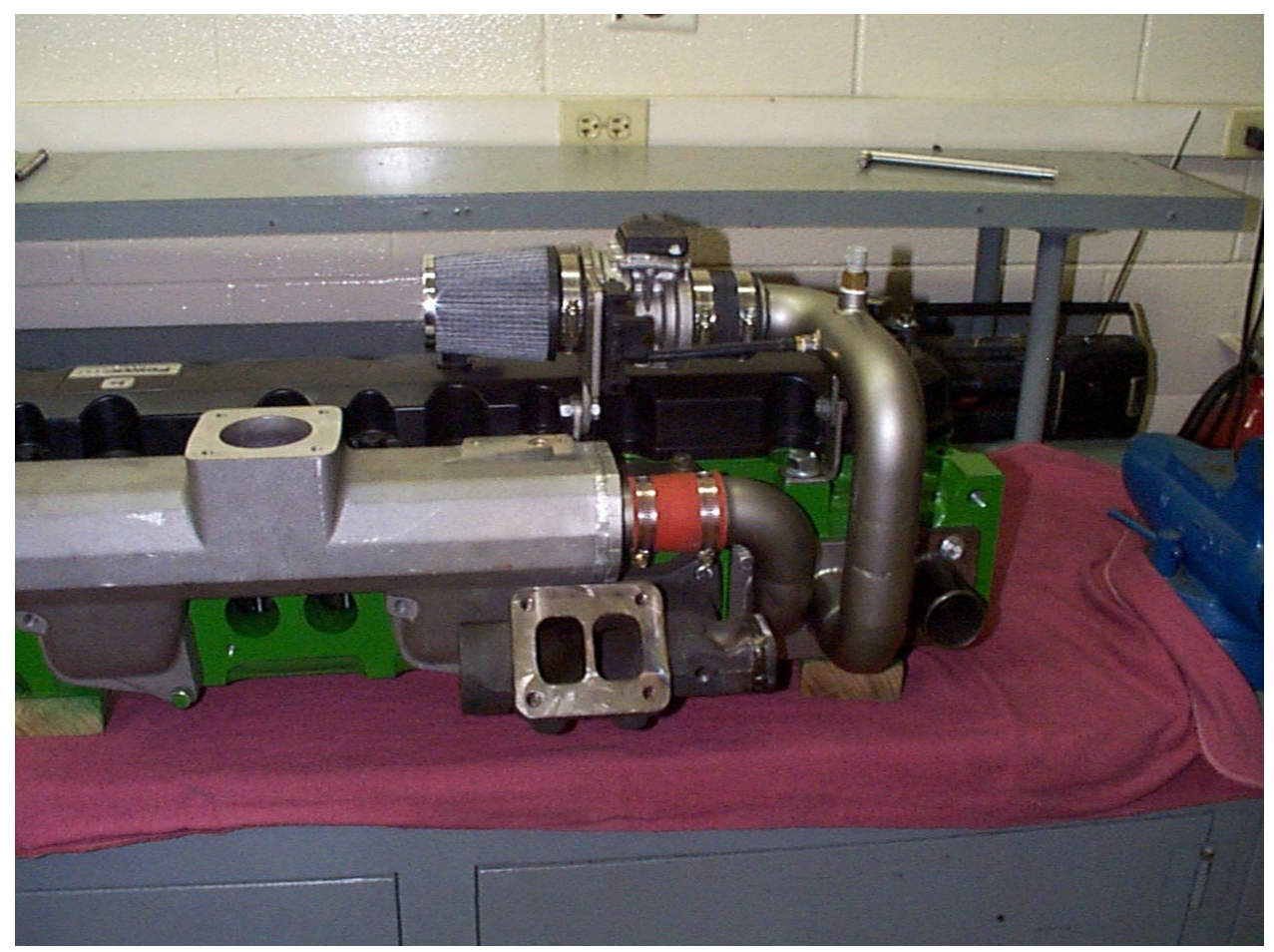

Figure 14. Side view of modified cylinder head showing split intake and exhaust systems 


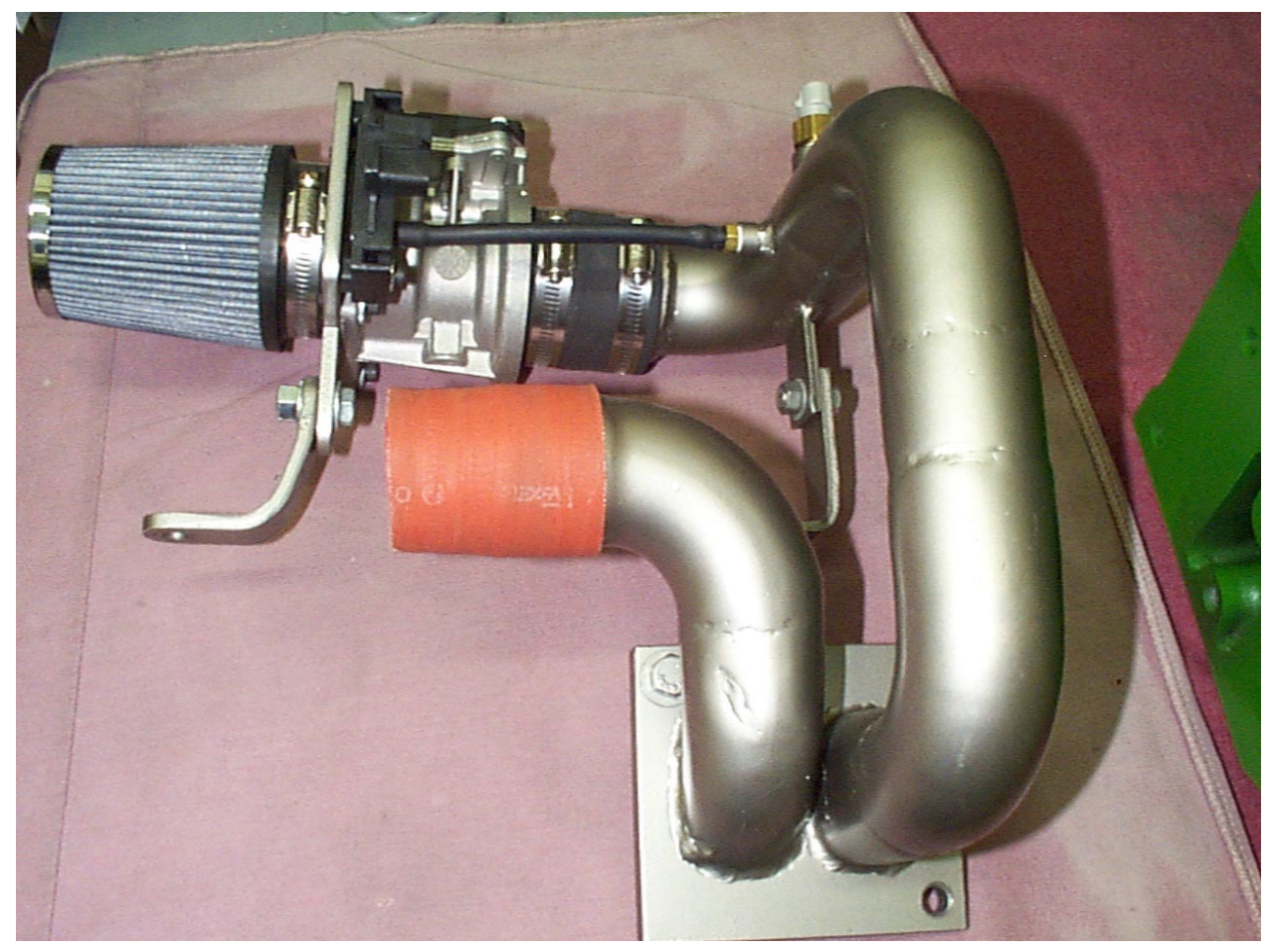

Figure 15. Split intake runner assembly with mass air flow sensor

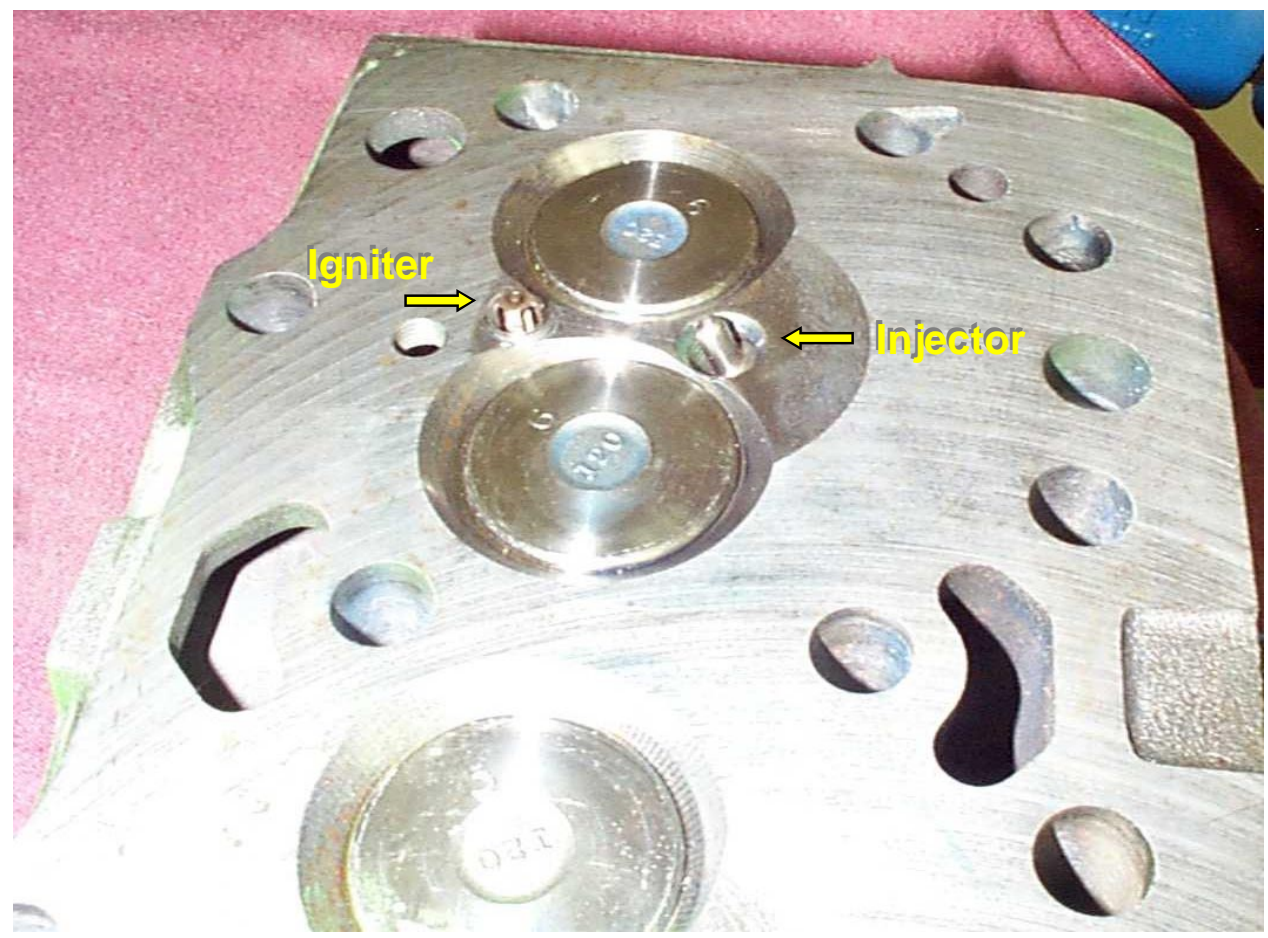

Figure 16. Photograph of injector nozzle and igniter plug locations in combustion chamber 


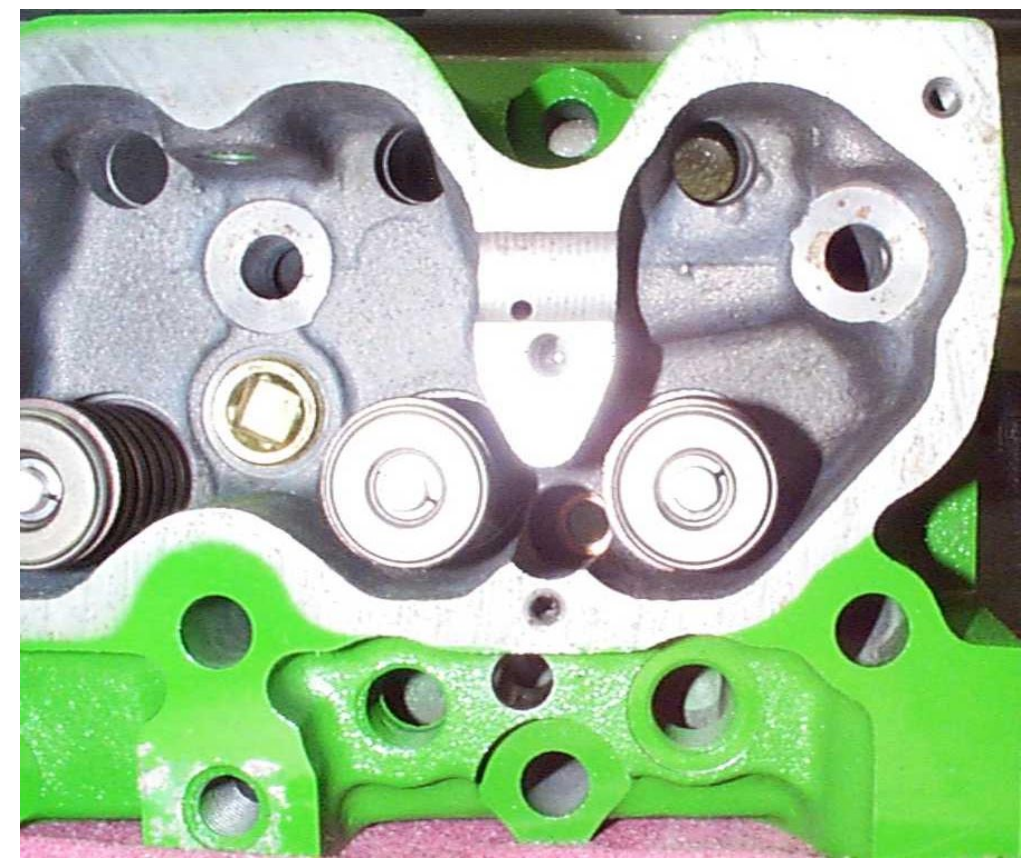

Figure 17. Photograph of holes machined to accept igniter plug tube

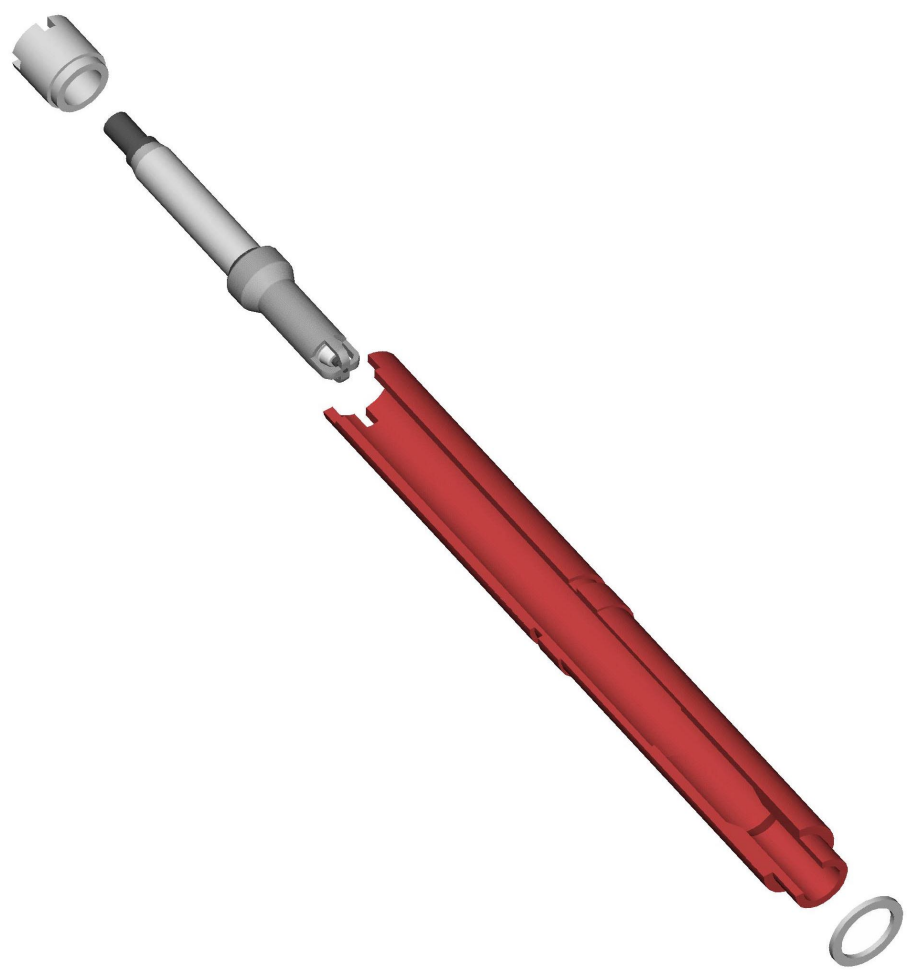

Figure 18. ProEngineer solid model of igniter plug adapter tube 


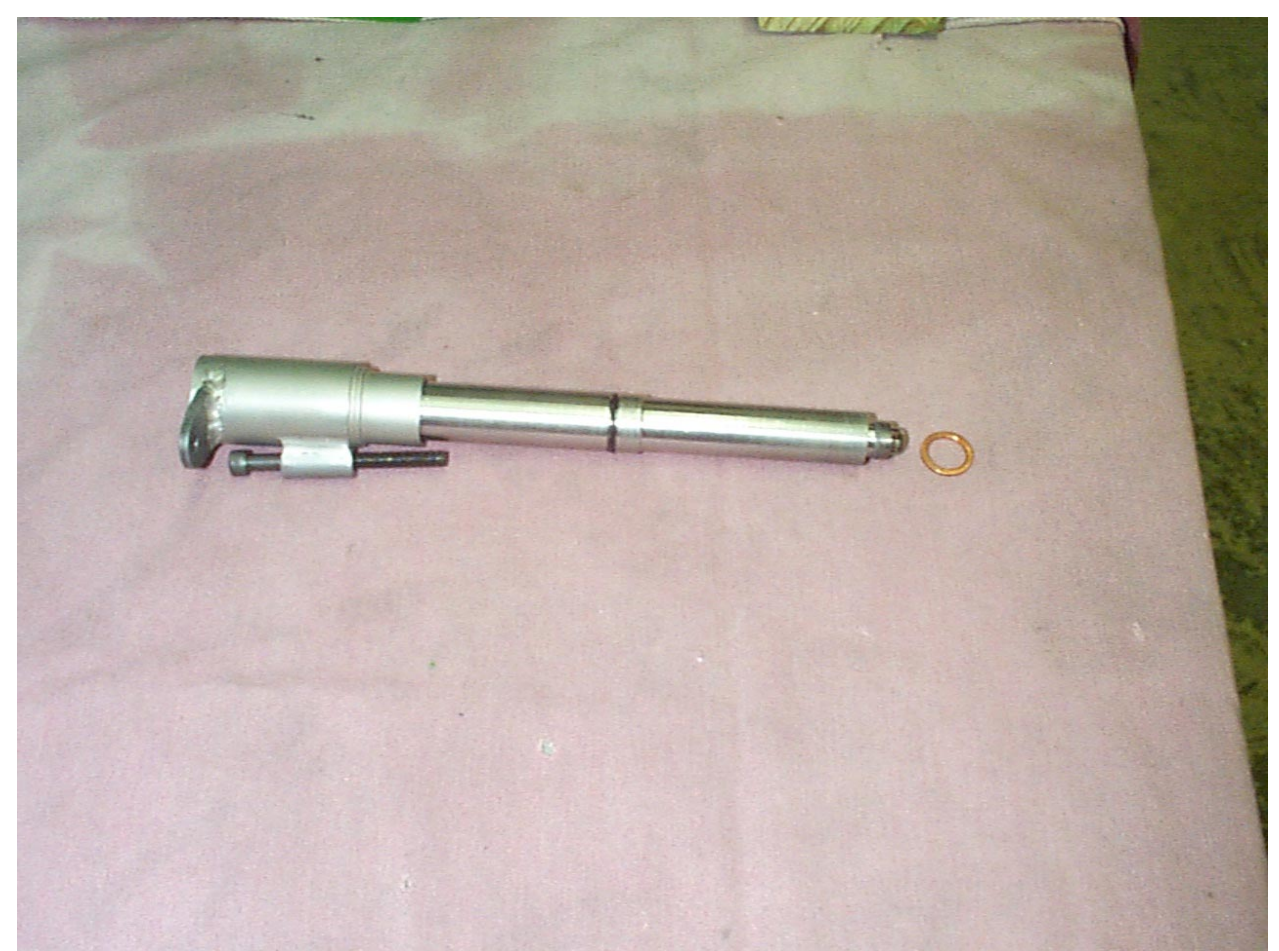

Figure 19. Photograph of completed igniter plug tube and coil-mounting sleeve

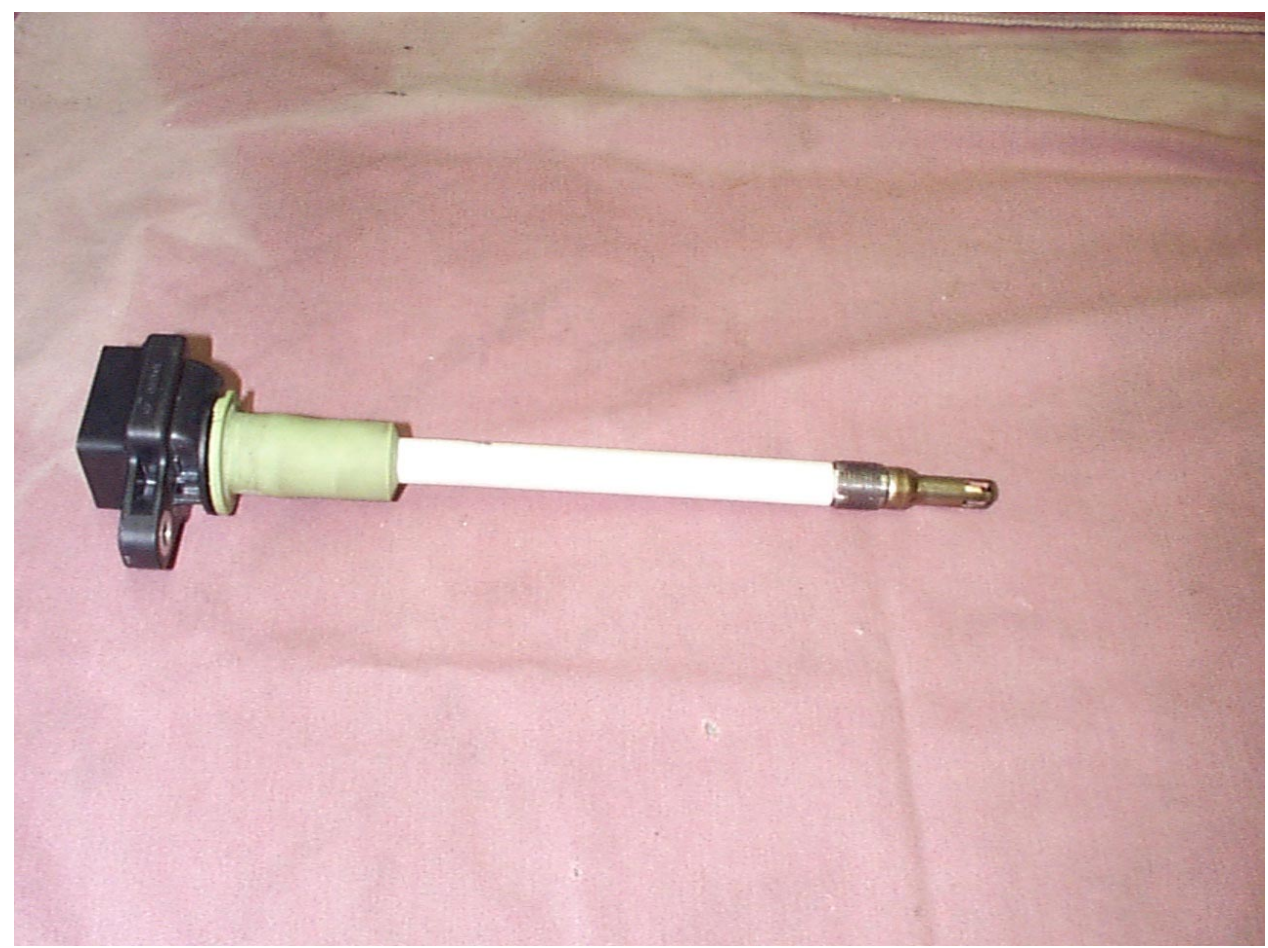

Figure 20. Coil-on-plug assembly 


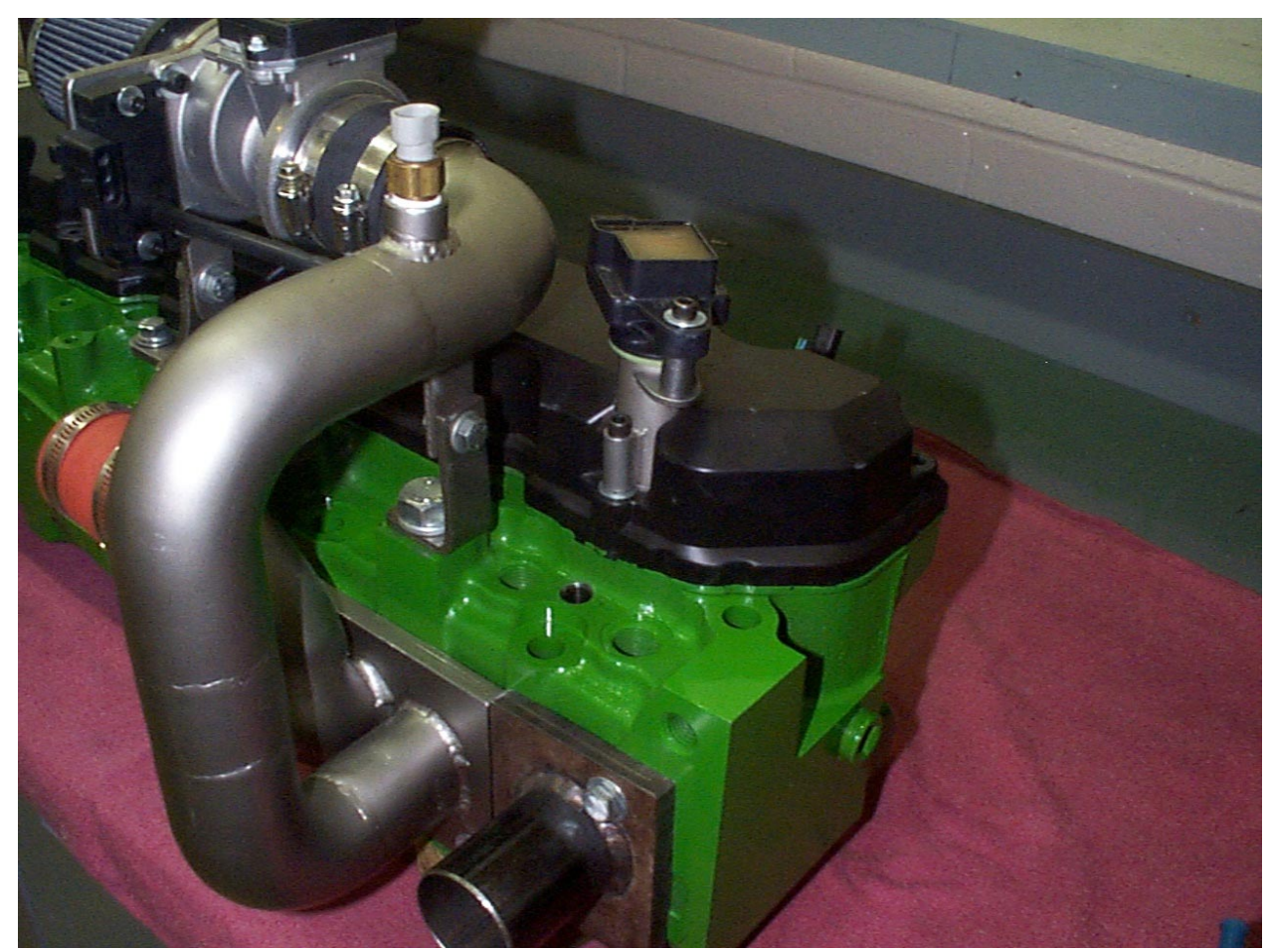

Figure 21. Photograph of coil-on-plug assembly installed in cylinder head

\section{Engine Control System Development}

A prototype engine control system was developed to support the engine testing conducted during the Experimental Program. The engine controller was based on the SwRI Rapid Prototyping Electronic Control System (RPECS). The RPECS is a personal computer-based controller platform which was developed to allow customization to various technical requirements. The RPECS which was used for the project was originally developed under the NREL school bus project and was modified during this project for the stratified charge and turbocharger experiments. The RPECS system featured control of the fueling, ignition, throttle, wastegate, and UEGO sensor functions. The RPECS system was designed to interface directly with the sensors and actuators on the production engine (i.e., fuel injectors, ignition coils, throttle actuator, etc.) and also accommodated additional hardware which was not used as part of the production engine control system.

Two versions of engine control software were developed for the project, one for conducting the VGT and enhanced wastegate experiments and one for conducting the combustion experiments. The control software developed for the enhanced wastegate and VGT experiments was more conventional and closely resembled the software developed during Phase II of the NREL school bus project. This version of the controller was fully transient capable and essentially retained all of the functionality of the production engine control system. The primary modification made in the RPECS, in order to accommodate the unique boost control requirements of this project, was the addition of an adaptive boost control algorithm. This was primarily necessary in order to adequately control the VGT. Since the engine was to be operated in a traditional homogeneous charge SI mode for the turbocharger experiments, the remaining portions of the engine controller were intentionally left unchanged. 
The engine controller modifications developed for conducting the combustion experiments required modification of both hardware and software. As discussed in the section entitled, "Cylinder Head/Manifold Modifications" found previously in this chapter, since cylinder \#6 was separated from the remaining cylinders, individual control of the fueling and ignition functions for cylinder \#6 was added. Additional sensors associated with cylinder \#6 were added. The additional sensors included intake manifold pressure and temperature sensors, fuel pressure and temperature sensors, and a UEGO sensor. The only additional actuators used were the direct fuel injector and the premixed fuel injector. The fuel control for cylinder \#6 was selectable to provide either a manual entry of the desired fuel mass per injection or an open loop control of overall fuel-air equivalence ratio. Because of the hydrocarbon effects on the UEGO sensor, closed loop control of the fuel-air equivalence ratio for cylinder \#6 was not used. The controller was also designed to allow separate fuel injection timing and ignition timing control for cylinder \#6. The five remaining cylinders were used in a traditional throttled homogeneous charge mode, with conventional control of fueling, ignition, throttling, and boost. Since the only cylinder of interest during the combustion experiments was cylinder \#6, the remaining cylinders were essentially used as a motoring dynamometer and no unique control functions were required. 


\section{Experimental Program}

The experimental work for the project was partitioned into four main areas: cylinder head flow bench testing, injector testing, combustion system development experiments, and turbocharger subsystem experiments. All but the turbocharger experiments were focused in the general area of developing the DISC engine concept. A detailed description of all the testing performed follows.

\section{Cylinder Head Flow Bench Testing}

In order to quantify the flow characteristics of the cylinder head, specifically for the stratified charge cylinder, the modified cylinder head was taken to the SwRI flow bench for testing. The primary objective of the flow testing was to identify the means of increasing or decreasing the swirl levels produced. The knowledge gained from this testing could then be used during the engine tests to achieve a desired change in swirl for the purposes of enhancing the stratified charge combustion process. The modified cylinder head was tested on the flow bench to measure the swirl level produced by the intake port. Swirl testing was conducted on both cylinder \#6, the stratified charge cylinder, and cylinder \#1, considered to be the baseline cylinder. Cylinder \#1 was used as the baseline cylinder since the intake port for cylinder \#6 had been modified with a divider plate to isolate that cylinder, and comparison between these two cylinders would then give an indication of the effect that this divider plate had on flow. Subsequent testing focused on obtaining different swirl levels by modifying the shape of the intake port using clay. Figure 22 shows a plot of non-dimensional swirl through the port as a function of valve lift. Four modifications to cylinder \#6 were made in an attempt to get both higher and lower swirl levels. In all cases, the swirl level was increased. In addition, the pressure drop across the port also increased. The testing also indicated that machining of the helical portion of the port would be required to lower the swirl level. This machining was not done, however, to preserve the integrity of cylinder \#6.

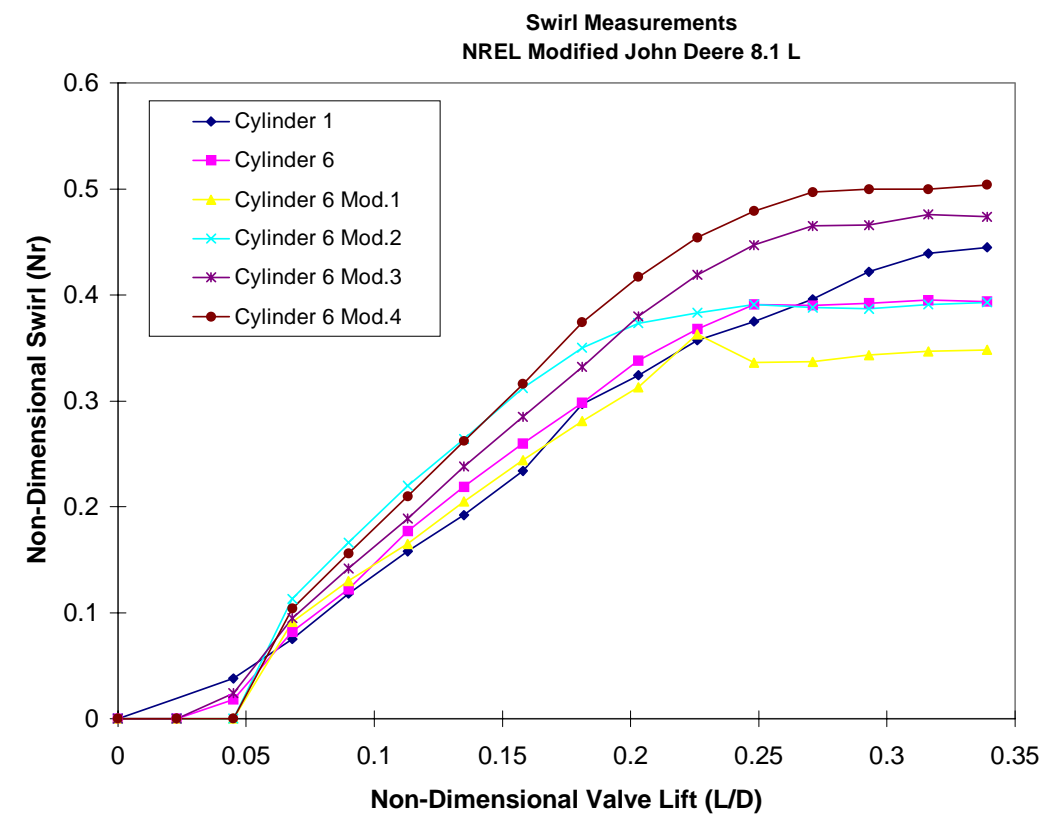

Figure 22. Plot of swirl testing results for cylinder head used in experimental program 
The maximum swirl level port profile was preserved using a RTV compound mold of the port. This mold could later be used to redefine the port geometry if the stratified charge experiments required a higher swirl level. A photograph of the intake port mold is shown in Figure 23.

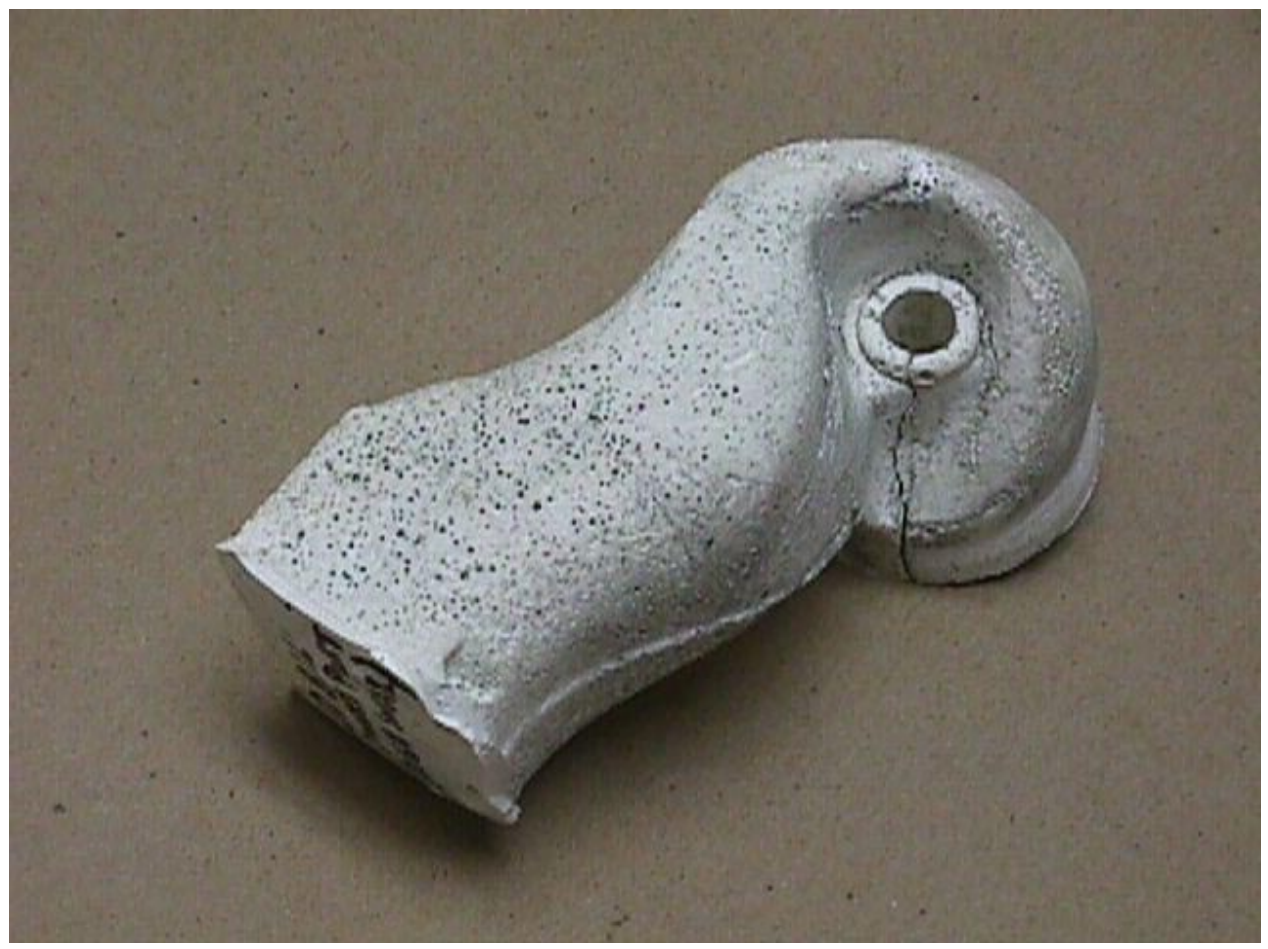

Figure 23. Mold of maximum swirl intake port profile

\section{Injector Testing}

Bench testing of the Sturman and CAP injectors used in the direct fuel injection system was conducted in order to verify the performance of the subsystem prior to engine testing. Several iterations of the Sturman injector were both bench and engine tested at SwRI. The Sturman injectors were found to have a high degree of sensitivity to downstream pressure. The later revisions of the Sturman injector were found to have adequate performance with downstream pressure levels on the order of $200 \mathrm{psig}$ in the bench test environment. However, when this injector was tested on the engine, injector performance was found to be unsatisfactory. One possible cause for the different performance between the engine and bench testing may have been that the check ball within the injector was not completely isolating the injector from the combustion pressures. In this case, the injector would see downstream pressures considerably higher than $200 \mathrm{psig}$, and thus cause unpredictable performance. Another possibility is that since the dynamics of the downstream pressure on the injector were different between the engine and bench test environments, these differences may have caused the different behavior between the two test environments. Ultimately, the Sturman injector was not used in the engine testing.

In addition to the Sturman injector, SwRI also tested a Servojet injector from CAP. The Servojet injector was found to work properly over the range of supply and downstream pressures, which were needed in the direct injection application for the project. The Servojet injector was operated over both bench and on-engine testing and was found to perform adequately enough to allow the direct injection engine experiments to begin. 
Two primary disadvantages were identified with the Servojet injector: injector leakage and turndown limitations. At zero pulse width and 500 psig natural gas supply pressure, the Servojet injector had leakage such that a hydrocarbon concentration of $3000 \mathrm{ppm}$ was measured from the test cylinder by the emissions bench during engine operation. This level of leakage could not be tolerated for the combustion experiments. Subsequently, several near-zero leakage injectors were supplied by CAP and the hydrocarbon levels measured at zero pulse width were found to be near $0 \mathrm{ppm}$.

The second disadvantage of the Servojet injector was related to the turndown capability of the injector. Engine testing showed that a minimum pulse width of roughly 4 milliseconds was required to reach air-fuel ratios of roughly 60:1. Based on previous SwRI experience with Servojet injectors, as well as information supplied by CAP, 4 milliseconds was very near the lower limit in terms of the injector's capability to accurately meter fuel. Therefore, if either the fuel pressure was increased or if leaner air-fuel ratios (and hence shorter injection durations) were required, the fuel metering accuracy and repeatability of the injectors was deteriorated.

\section{Combustion System Development Experiments}

The majority of the Experimental Program task involved testing and development of the combustion system and strategy for the engine. Since the overall operating strategy for the engine involved conventional homogeneous charge SI combustion, similar to that used in the production engine, over most of the engine operating range, a relatively small amount of effort was spent on this operating mode. Alternatively, since light load operation would require a new operating mode, i.e., stratified charge SI operation, the vast majority of the combustion system development effort was spent on the DISC concept. Details of all the combustion system development is contained in the following subsections.

\section{Stratified Charge Combustion Experiments}

As shown in the section entitled, "Direct Injection System Analysis" found in the previous chapter, in order to achieve throttleless SI operation over the entire engine operating range, the engine needed to operate at fuel-air equivalence ratios well below the lean limit of a homogeneous natural gas-air charge. Therefore, a means of stratifying the fuel-air charge was needed such that an ignitable mixture was achieved near the spark plug at the time of ignition. A variety of stratified charge approaches have been investigated by other researchers with varying degrees of success. Given that a diesel-like diffusion burn approach over the entire operating range was not felt to be desirable for emissions reasons, approaches which were considered for solving this problem included a prechamber combustion approach, a port injection open chamber combustion approach, and a direct injection open chamber approach. The advantages and disadvantages of each of these approaches was considered.

A great deal of work has been done using the prechamber combustion approach with natural gas. SwRI has achieved extremely low emissions and high efficiency with prechamber engines operating on natural gas by using very small prechamber volumes, on the order of 2 percent of the volume of the main chamber. However, in order to achieve throttleless operation over the entire operating range, a much larger prechamber, i.e., 10 percent or more of the main chamber volume, would be required. SwRI's experience with engines having prechambers this large has shown that these engines suffer significant emissions penalties. For this reason, a traditional prechamber approach was determined inappropriate for this engine.

Previous work has also been done using properly timed port fuel injection to achieve charge stratification in an open chamber SI engine. This approach would be attractive from the perspective of not forcing significant modifications to the production engine, i.e., no cylinder head changes would be required and the production engine already uses suitable fuel injectors for port injection. However, this approach was not likely to 
provide the level of stratification needed for throttleless operation at very light load conditions. This hypothesis was further supported by the direct injection experimental data. For this reason, the port fuel injected open chamber approach was not investigated.

The approach which was tested on the engine, was a direct injection open chamber SI engine system. Variations of this approach have been successfully developed on light-duty gasoline engines for improving part-load efficiency. These engines are now finding their way into the marketplace and are gaining acceptance in the passenger car industry. The DISC approach was felt to be the best option for allowing throttleless operation, and thus high efficiency, with the lowest emissions penalties relative to a homogeneous charge SI approach. The DISC approach also accommodated the transition into the traditional homogeneous charge approach, or a hybrid stratified charge/homogeneous charge approach for medium to high load operation. For this reason, the DISC approach was the focus of the stratified charge combustion system development effort.

Initial stratified charge combustion engine testing. The goal of the initial engine testing of the DISC concept was to verify the operation of the new and modified hardware including the direct injection fuel system, modified spark plug tube, and engine control system. A photograph of the test engine configuration in the test cell is shown in Figure 24. As shown in the photograph, cylinder \#6 was isolated using modified intake and exhaust systems. The direct injection system was located in the spark plug hole for cylinder \#6, and an alternative spark plug location was provided with a custom tube through the water jacket.

As an initial investigation of the engine performance using the direct injection system, the engine was operated at a steady-state condition, at an intermediate speed (i.e., $1200 \mathrm{rpm}$ ), with only the five homogeneous cylinders operating. Fuel was then metered to the test cylinder in sufficient quantities to allow combustion to begin.

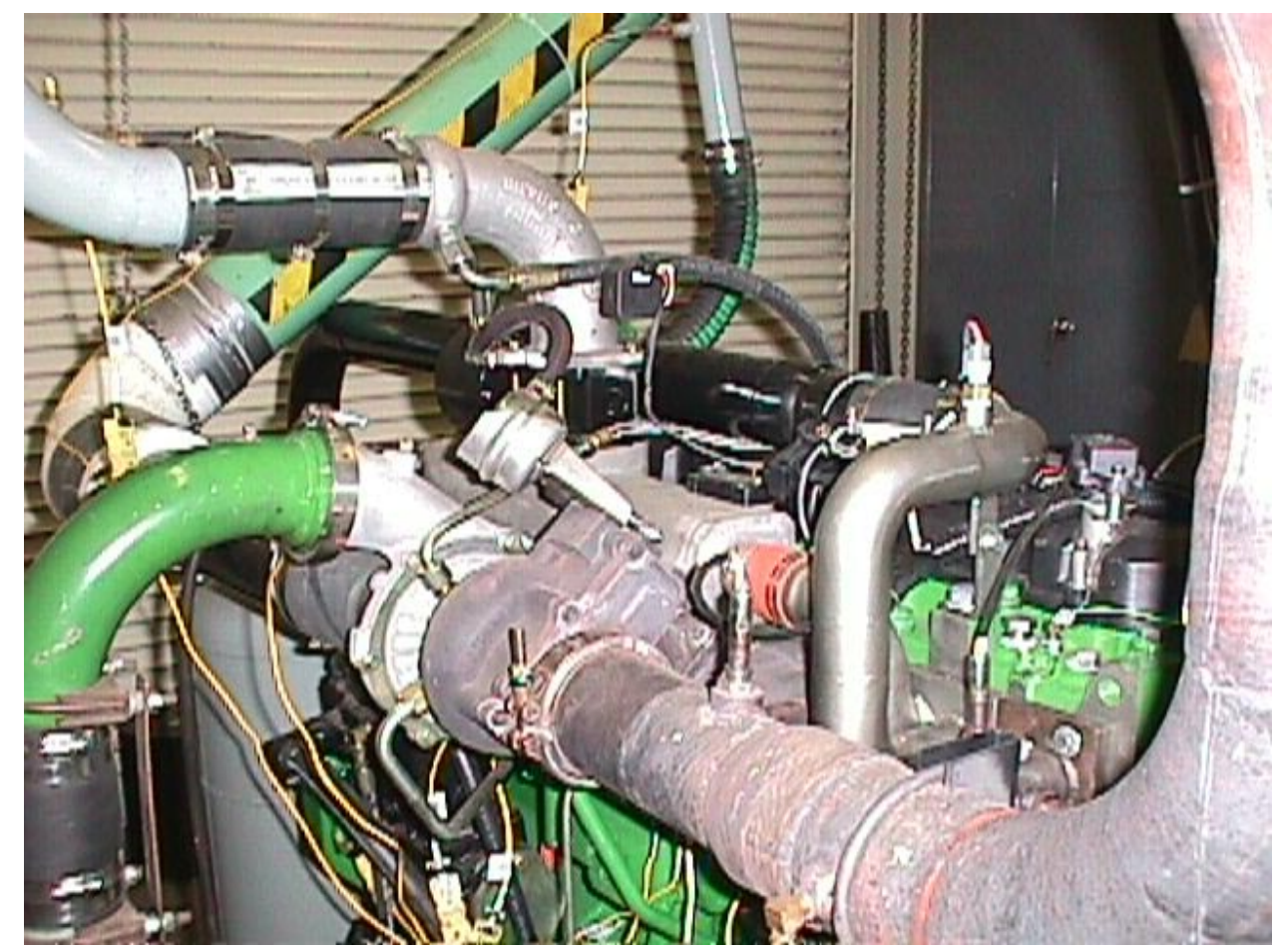

Figure 24. Modified engine used for stratified charge combustion tests 
Two injector nozzles were tested on the engine with quite different results. The first injector nozzle tested was a three-hole nozzle which featured a small center hole that was pointed at the spark plug, as well as a larger hole on either side of the center hole. The design of the three-hole injector nozzle was discussed in the "Direct Injection" portion of this report. A closeup view of the nozzle is shown in Figure 25.

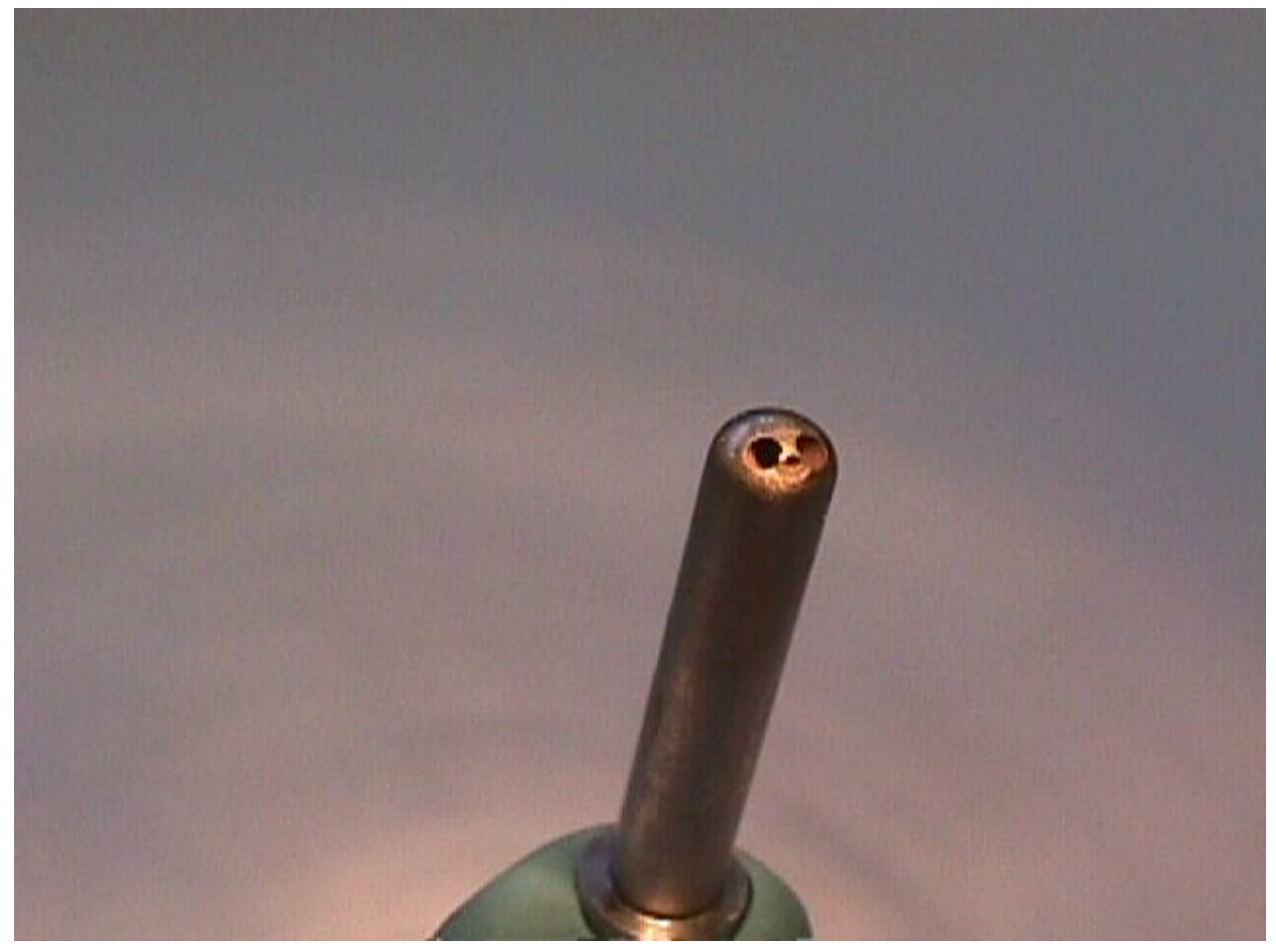

Figure 25. Enlarged photograph of three-hole injector nozzle

Reliable combustion with the three-hole nozzle was only achieved with early cycle injection, (i.e., injection during the intake stroke). When late cycle injection was attempted, inconsistent combustion (i.e., many misfiring or near misfiring cycles) or no combustion at all was observed. This was found to be true over a variety of end of injection (EOI) timing and spark timing value combinations. Given this trend, it was believed that the engine was firing under a homogeneous charge mode and that stratified charge combustion was not being achieved. This was further supported by the fact that the lean equivalence ratio limit for combustion to occur appeared to be similar to that of a traditional open-chamber, lean-burn engine (i.e., on the order of 0.60 equivalence ratio).

Given the preliminary results obtained with the three-hole injector nozzle, a five-hole injector nozzle was subsequently tested. The five-hole nozzle retained the same total flow area as the three-hole nozzle; however, the spray pattern for the five-hole nozzle was spread over a larger area and the hole size of the largest holes was considerably less than those of the three-hole nozzle. The five-hole nozzle featured the same size center hole as the three-hole nozzle. A closeup view of the five-hole nozzle is shown in Figure 26. 


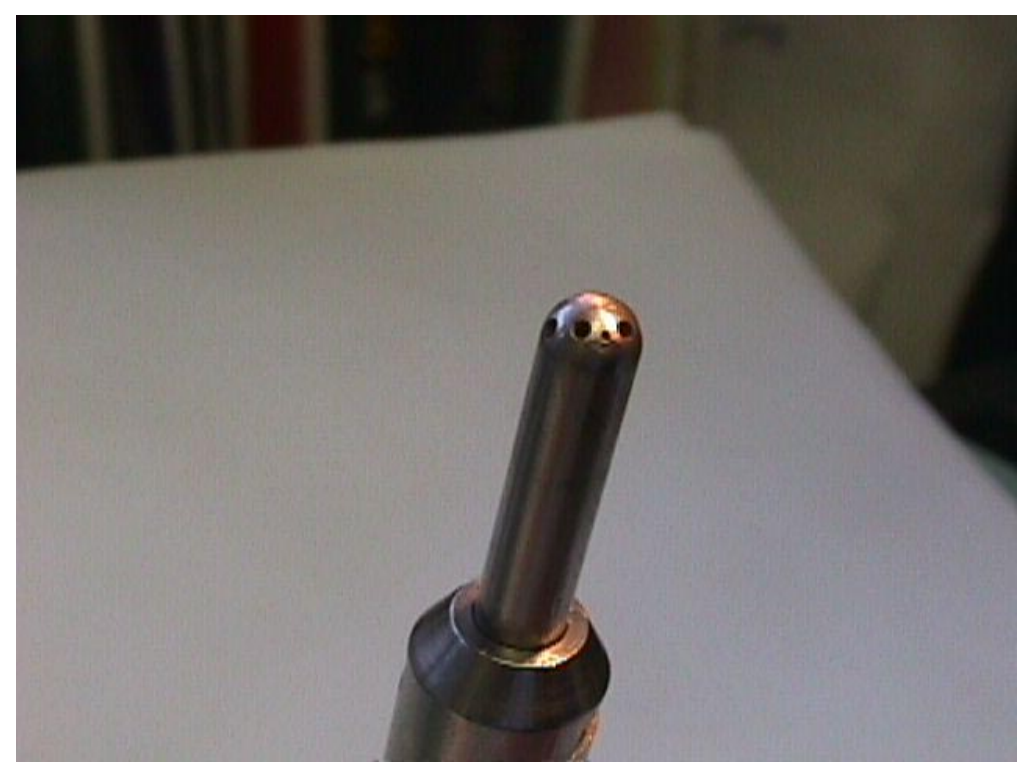

Figure 26. Enlarged photograph of five-hole injector nozzle

Engine test results with the five-hole nozzle were encouraging. In addition to stable combustion in the early cycle injection mode, late cycle injection over a specific range of EOI and spark timing combinations also yielded stable combustion. Furthermore, the overall equivalence ratio values which sustained adequate combustion were well beyond those which could be achieved with a traditional open-chamber, lean-burn engine. Equivalence ratios of roughly 0.30 were measured by the emissions bench. This was compelling evidence that the stratified charge combustion strategy was working. Using this system, the load on the test cylinder also could be reduced by decreasing the fuel flow to the cylinder. Figure 27 shows how the indicated mean effective pressure (IMEP) of the test cylinder was reduced as the overall A/F ratio was increased (i.e., fuel flow was decreased). Indicated power measurements, with an estimated accuracy of 1 percent, were used to define the load on the cylinder since it was difficult to independently ascertain the brake power output of the single test cylinder.

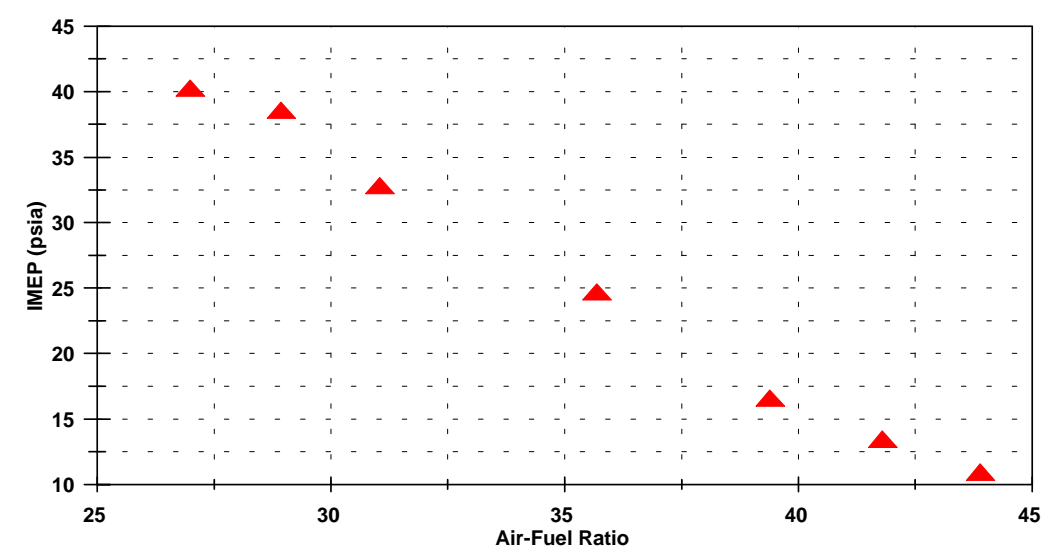

Figure 27. IMEP as a function of $A / F$ ratio for stratified charge operation at 1200 RPM 
In testing the late cycle injection concept, it was observed that injection events which ended after or just prior to the spark ignition event yielded misfiring cycles. Furthermore, it was found that there was an "optimum" time duration between the EOI and spark event which qualitatively seemed to yield the most stable and repeatable combustion. Independent of engine speed, the optimum time duration between the EOI and spark event (i.e., the time between the commanded EOI and the spark event) was between 4.5 and 5.5 milliseconds. This time interval is composed of two parts: the injector closing response time (i.e., the time between the commanded and actual EOI event) and a post-injection fuel mixing period. The injector closing response time was estimated to be roughly 2 milliseconds. The remaining interval was a "Terrxing time" of about 2.5 to 3.5 milliseconds necessary to allow the fuel and air within the cylinder to mix in order to produce an ignitable mixture at the spark plug and allow combustion to occur. This indicated that combustion was occurring in a premixed manner localized near the spark plug. This was further supported by the fact that very advanced spark timing values were necessary to achieve the most stable combustion (i.e., as much as 40 degrees BTDC spark timing at 1200 RPM). Emissions measurements from the test cylinder also indicated premixed combustion trends, although hydrocarbon emissions indicated incomplete combustion. $\mathrm{NO}_{\mathrm{x}}$ emissions were found to be relatively low (i.e., roughly $200 \mathrm{ppm}$ at the lowest load conditions), while total hydrocarbon emissions were extremely high. Combustion analysis using measured cylinder pressure records also supported the case that premixed combustion was occurring. Figure 28 is a plot of a cylinder pressure record for one of the test runs, along with the calculated heat release rate for this record. The heat release rate history calculated for this run indicated that the combustion rate was relatively slow. A slow combustion rate implied that lean, premixed combustion was occurring.

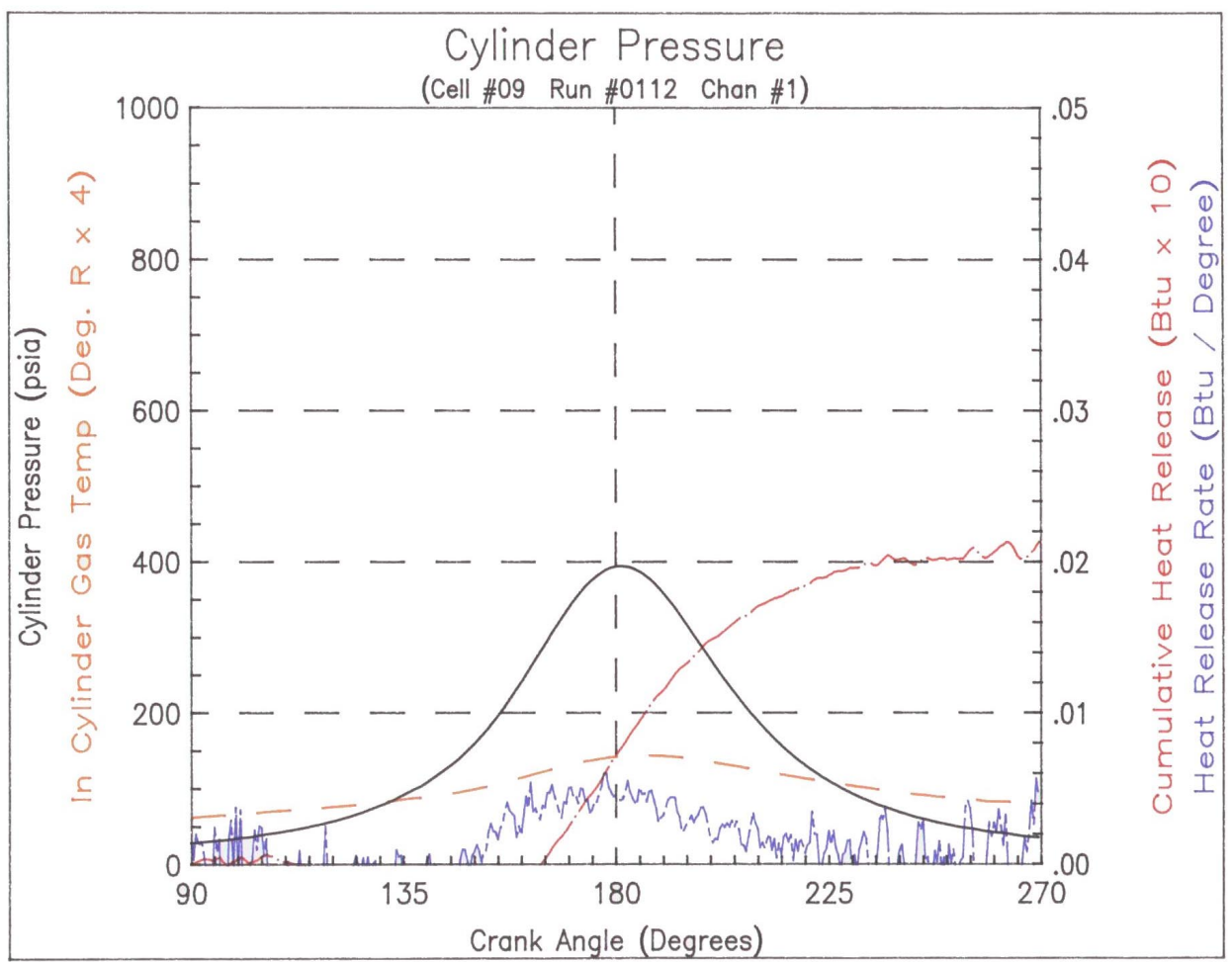

Figure 28. Cylinder pressure record for stratified charge operation 
Instrumentation Modifications. As a result of the initial engine testing it was decided that some additional instrumentation was needed in the test cell and also that some modifications were required for purposes of improving the quality of the mass air-fuel ratio measurement. A stand-alone hydrocarbon analyzer was installed in the test cell. This analyzer, a Beckman (Rosemount) 400A HC analyzer, was suitable for unburned hydrocarbon measurements from gaseous-fueled engines, and was simple to install and operate on a daily basis. A heated sample pump enclosed in a temperature controlled oven was used to sample gas from the exhaust stream, and heated lines were used to transfer this sample to the analyzer. Figure 29 shows the $\mathrm{HC}$ analyzer and sampling train as installed in the test cell.
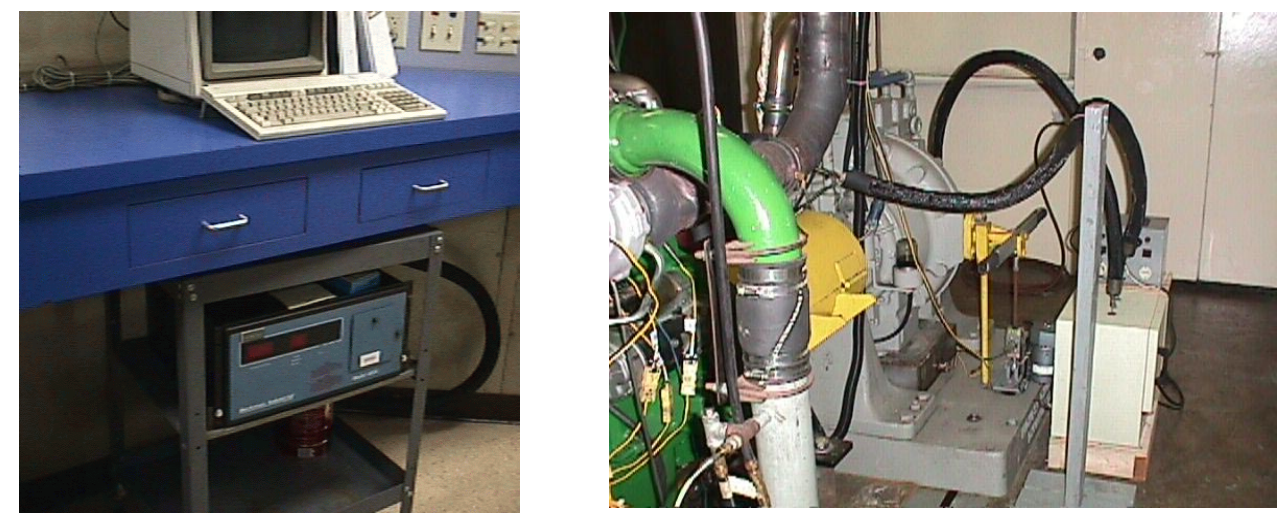

Figure 29. HC analyzer and sampling apparatus

In addition to the $\mathrm{HC}$ analyzer, a fast response $\mathrm{NO}_{x}$ sensor from $\mathrm{NGK}$ was installed in the exhaust system of the test cylinder in order to give a rough indication of the $\mathrm{NO}_{\mathrm{x}}$ emissions from the test cylinder. These two instruments allowed measurement of total hydrocarbon and $\mathrm{NO}_{\mathrm{x}}$ emissions on a daily basis without requiring the use of the emissions bench.

A separate Micromotion fuel flow meter was added to the test cell to measure fuel flow to the test cylinder. This was needed so that accurate air-fuel ratio measurements could be made for the test cylinder. In addition, an RMS to DC convertor was applied to the mass air flow sensor signal for the test cylinder. The convertor was quite effective in accommodating the highly pulsating air flow of the test cylinder. These additional instrumentation improvements helped allow the DISC concept modifications to be more quickly and accurately assessed.

Operational Strategy Change. The experimental findings early in the DISC concept development indicated the engine was operating in a premixed charge mode. These findings led to a change in the operational strategy of the engine. The combustion system had been designed to operate in a non-premixed mode similar to a spark-ignited diesel or multifuel engine. To accomplish this, the injector nozzle had been designed to produce specific A/F ratio contours near the spark plug. The spark plug would then be used to ignite the fuelair mixture near the periphery of the jet. This method had some inherent difficulties, however, in that the A/F ratio contours of the jet pattern were quite steep, meaning that the $\mathrm{A} / \mathrm{F}$ ratio within the jet was varying considerably over a small distance. In order to get repeatable ignition, the jet must be positioned so that a flammable region was located in the vicinity of the spark gap at the spark event. Previously within this report the use of computer simulations to predict the $\mathrm{A} / \mathrm{F}$ ratio distribution in the jet, were discussed. These simulations were used to design small hole nozzles that would effectively "flood" the spark gap area with an ignitable mixture. However, these small holes were too restrictive for the overall flow rate through the injector, so additional large holes were designed into the nozzle to provide the required flow rate. Interaction between the jets from the small and big holes could change the A/F ratio contours at the spark plug. In addition, any air motion effects due to swirl or squish that were unaccounted for in the design process would also change the location of the flammable $\mathrm{A} / \mathrm{F}$ regions. 
An alternative process was, therefore, pursued following the realization that the engine was operating in a premixed mode. Other modern spark-ignited, stratified charge engines, notably the gasoline direct injection engines being developed by Toyota, Nissan, and Mitsubishi, stratify the charge by injecting fuel into a shallow bowl in the piston that spans the injector and spark plug. These engines are somewhat different in that the majority of the combustion chamber volume is in the head, compared to the large bowl-in-piston combustion chambers required in natural gas engines derived from heavy-duty diesel engines with vertical valves and a flat fire deck. The piston was redesigned to incorporate a divided bowl structure.

Piston Modifications. To incorporate the change in operational strategy, a new piston was designed. In the modified piston design, the piston bowl remained the primary combustion chamber, but the bowl was divided into two sector-shaped regions. One sector of the bowl included the combustion chamber volume directly below the injector tip and the spark plug gap. The other sector constituted the remaining combustion chamber volume. A photograph of the piston is shown in Figure 30.

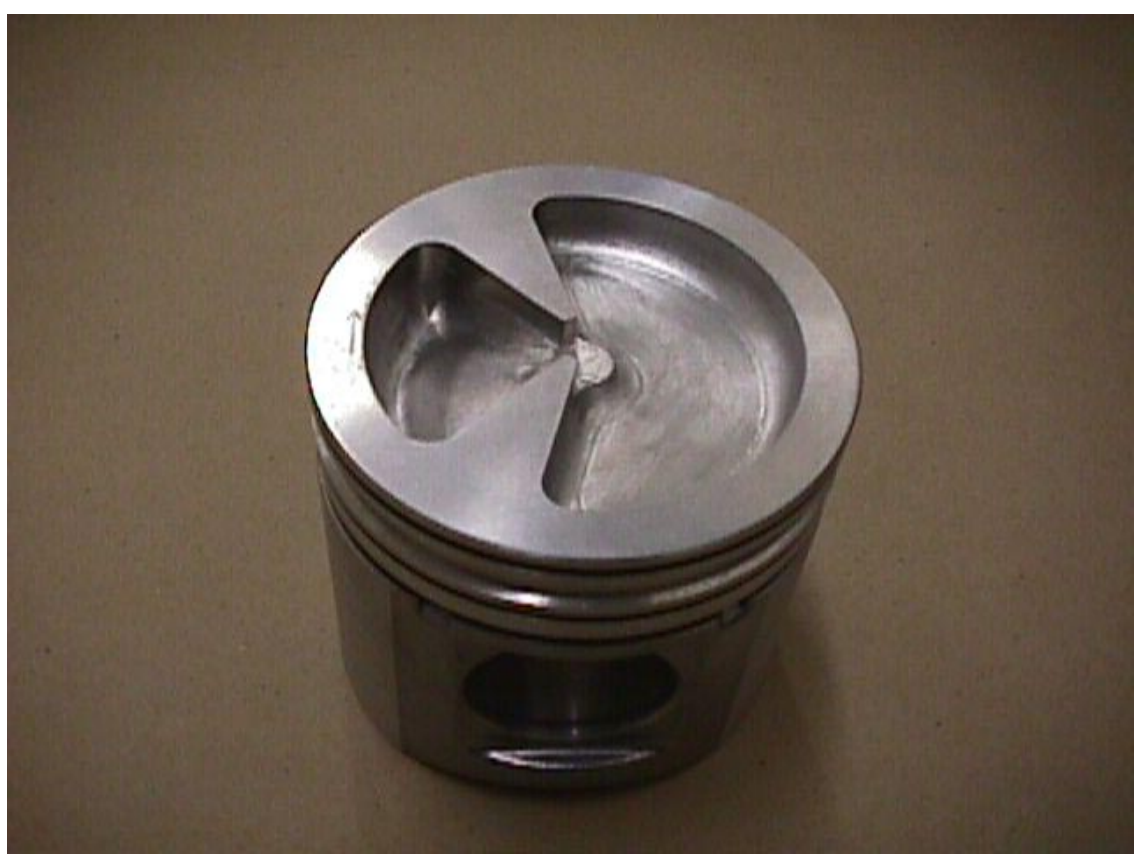

Figure 30. Divided bowl combustion chamber piston 
The relative sizes of the combustion bowls were calculated using assumed operational characteristics of the engine. For example, a minimum operating torque of $80 \mathrm{ft}-1 \mathrm{bs}$ was assumed, since this is the value for curb idle transmission torque that has been used in the past to set the minimum load on the engine for transient emissions testing. For this condition, a fuel-air equivalence ratio of 0.70 was selected, which represented a conservative lean limit at the minimum torque level. Assuming a stoichiometric A/F ratio of natural gas to be 16.5 , the A/F ratio within the primary combustion bowl should be $16.5 / 0.7=23.6$. Previous model results showed that, assuming throttleless operation, the overall $\mathrm{A} / \mathrm{F}$ ratio at the $80 \mathrm{ft}-1 \mathrm{bs}$ level was approximately 70. The primary bowl fraction was set at $23.6 / 70.0=0.337$. The minimum overall $\mathrm{A} / \mathrm{F}$ ratio that can be run using late injection stratified charge combustion would be when operating stoichiometrically in the primary bowl, which would give an A/F of 16.5/0.337 = 49.0, or approximately $135 \mathrm{ft}$-lbs load. Above this load level, a transition to an alternate combustion mode must begin.

Piston cross sections were examined to determine the maximum bowl depth available. Volume calculations were done on several bowl configurations to determine a practical solution in terms of primary bowl width and depth. In order to reduce the overall bowl volume required, the target compression ratio was increased to 12.0 .

A flat top piston supplied by Deere was used to prepare the new piston. A CNC milling machine was used to generate the rough bowl geometries. The bowls were finished using a hand grinder to obtain smooth contours between bowls, and the piston was buffed to give a smooth surface finish. Following the final machining, the bowl volume was measured to determine the compression ratio. The calculated compression ratio was found to be 12.26 , slightly higher than the target compression ratio of 12.0 .

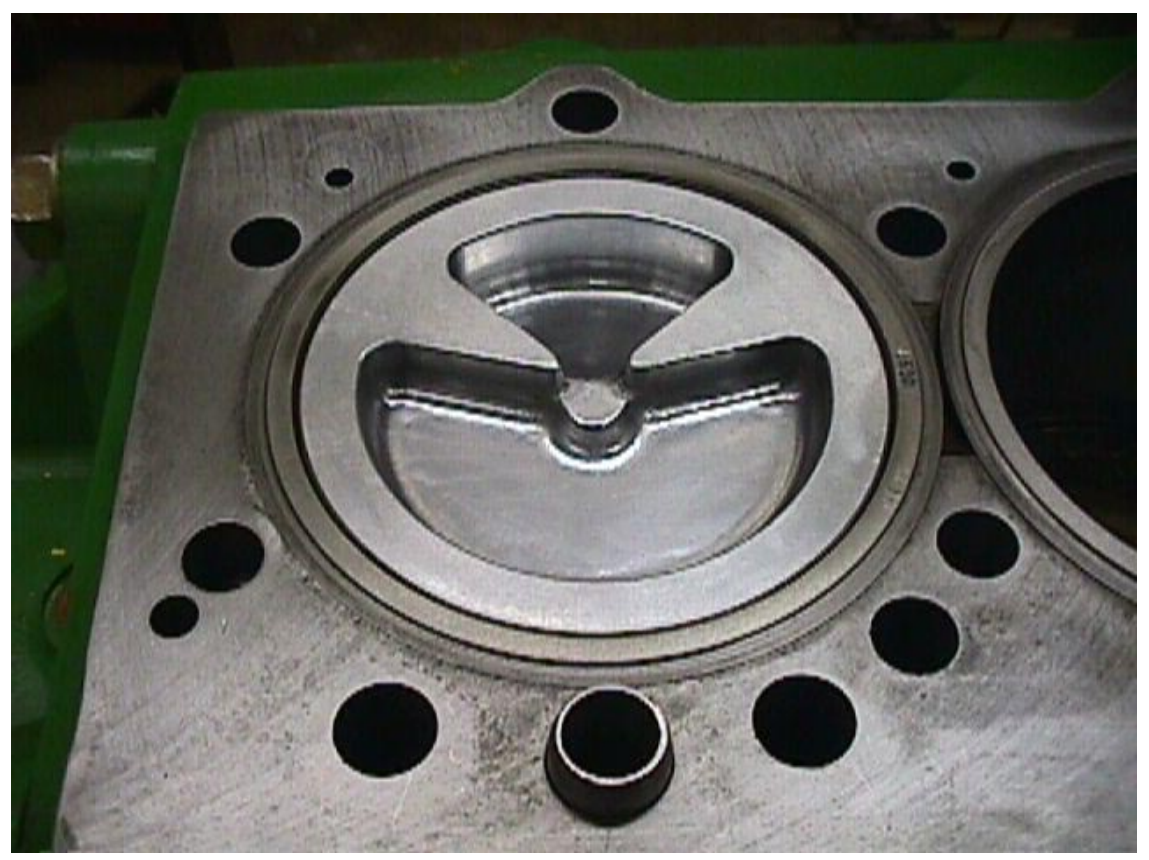

Figure 31. Divided bowl piston as installed in test engine 
Engine Testing with Revised Operational Strategy. The engine was rebuilt with the divided combustion chamber piston bowl. The existing 3-hole and 5-hole injector nozzles were tested to determine if they were suitable for use with the new combustion system. Tests proved that these nozzles were not suitable, since they could not provide stable combustion. These nozzles also produced extremely high hydrocarbon (HC) emissions which indicated that a great deal of fuel was bypassing the combustion process. To counteract this, a simple nozzle was fabricated by taking one of the shallow angle, multi-hole nozzles from previous experiments and cutting the end off, exposing the center drilling. This formed a nozzle with a large, single hole that vectored the fuel directly down into the primary combustion bowl.

Initial results with the single hole nozzle were encouraging. Operating parameters were found that resulted in stable engine operation. Unburned hydrocarbon (HC) emissions were still relatively high, but lower than those measured with the shallow angle hole nozzles. Advanced injection and spark timings were still required for stable operation. Analysis of cylinder pressure records showed that the combustion event was occurring well before top dead center (TDC). The advanced injection timings were thought to prevent any major change in spark timing that could delay the combustion process until after TDC, thereby raising the efficiency of the combustion process.

A working hypothesis was developed concerning the need for advanced injection timings: a given amount of time was required to prepare a flammable mixture near the spark plug, and advanced injection timings were required to provide this "mixing" time. To counter this problem, methods to accelerate mixing of the fuel and air were examined. The most practical method appeared to be the use of a nozzle with a large number of small holes. A nozzle of this type would be expected to provide less penetration and more mixing than a single large hole nozzle. Design of alternative nozzles was pursued based on this assumption.

Injector Nozzle Modifications. Conceptual design for new multi-hole nozzles resulted in two new designs: a six-hole nozzle and a nine-hole nozzle. These nozzles were expected to provide a greater level of mixing, and the hole pattern was designed to fit the combustion chamber geometry. To assist in the design and fabrication of the nozzles, ProEngineer 3-D solid models were prepared for each nozzle. A solid model of the combustion chamber that showed the relationship between the injector nozzle and the combustion bowl was also prepared. This model was used to illustrate the dispersion of the fuel jets and the resulting placement of the fuel in the primary combustion bowl. Figures 32 and 33 illustrate the solid models for the six and nine hole nozzles, respectively.

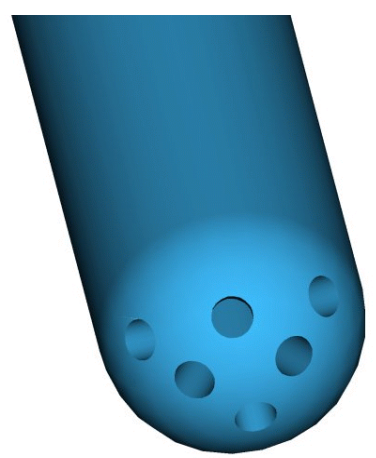

Figure 32. 6-hole nozzle direct injector 


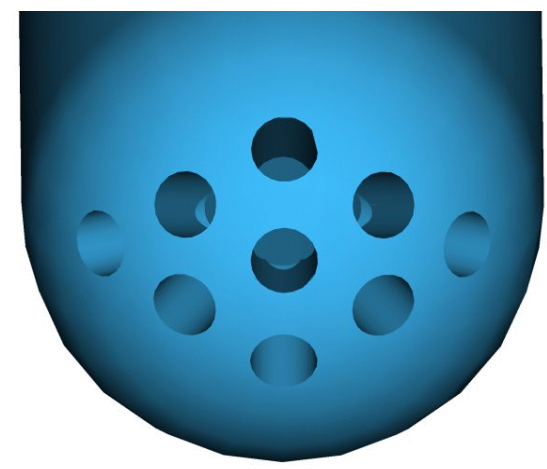

Figure 33. 9-hole nozzle for direct injector

The nozzles were fabricated from Waspalloy blanks using electrodischarge machining (EDM) to produce the array of small holes.

Testing of Modified Injector Nozzles. The two new nozzles were subsequently tested on the engine. Unburned HC emissions measurements from the test cylinder and the exhaust port temperature were used to screen each nozzle's performance. Observation of the cylinder pressure trace on the oscilloscope was also used to gauge the combustion stability. Initial testing with the new nozzles showed that HC emissions were higher than those from the open nozzle under similar conditions. The combustion stability also appeared to have deteriorated when using these nozzles.

Repeated attempts to optimize the injection and combustion process were not successful in finding a combination of parameters that allowed stable operation with late injection timing. Late injection timings should have guaranteed that the fuel entered and remained in the combustion bowl. However, the combustion bowl may have been overly rich near the spark plug which prevented stable combustion with late timing.

Since the best results had been obtained with the single hole nozzle, the injector was refitted with this nozzle. The engine was operated briefly to determine if the performance of the combustion process was repeatable. After confirming this, a comprehensive test matrix was prepared. Table 2 contains the test points that were considered for this test plan.

Table 2. Test Matrix for Stratified Charge Combustion Evaluation

\begin{tabular}{||c|c|c|c||}
\hline $\begin{array}{c}\text { Speed } \\
(\mathbf{r p m})\end{array}$ & $\begin{array}{c}\text { End of Injection (EOI) } \\
\left({ }^{\circ} \text { BTDC) }\right.\end{array}$ & $\begin{array}{c}\text { Spark Timing } \\
\left({ }^{\circ} \text { BTDC) }\right.\end{array}$ & Desired Equivalence Ratio \\
\hline 650 & 60 & $25,28,31$ & $0.33,0.36,0.39,0.45,0.50,0.55,0.60$ \\
\hline 1200 & 70 & $31,34,37$ & $0.33,0.36,0.39,0.45,0.50,0.55,0.60$ \\
\hline 1800 & 85 & $37,40,43$ & $0.33,0.36,0.39,0.45,0.50$ \\
\hline
\end{tabular}


Due to a problem with the gas pressure sensor on the gas injector assembly, the actual equivalence ratio obtained during testing was somewhat different from the desired since the engine control system was operating in an open loop manner. Nevertheless, the data collected did cover the range of engine operation shown in the test matrix. Figure 34 is a plot of a portion of the data collected. It shows indicated mean effective pressure (IMEP) levels for each test point. Each test point is also labeled with the equivalence ratio measured by the emissions bench at that test point. Note that nearly all of the points shown had equivalence ratios that were well below the normal lean misfire limit equivalence ratio. This confirmed that a stratified combustion process was occurring. In addition, this plot shows the range of power output that was attained under throttleless conditions, and it also illustrates the diesel-like nature of the stratified charge engine, i.e., that load is increased by increasing the equivalence ratio.

A plot of indicated thermal efficiency (ITE) as a function of IMEP for all data points is shown in Figure 35.

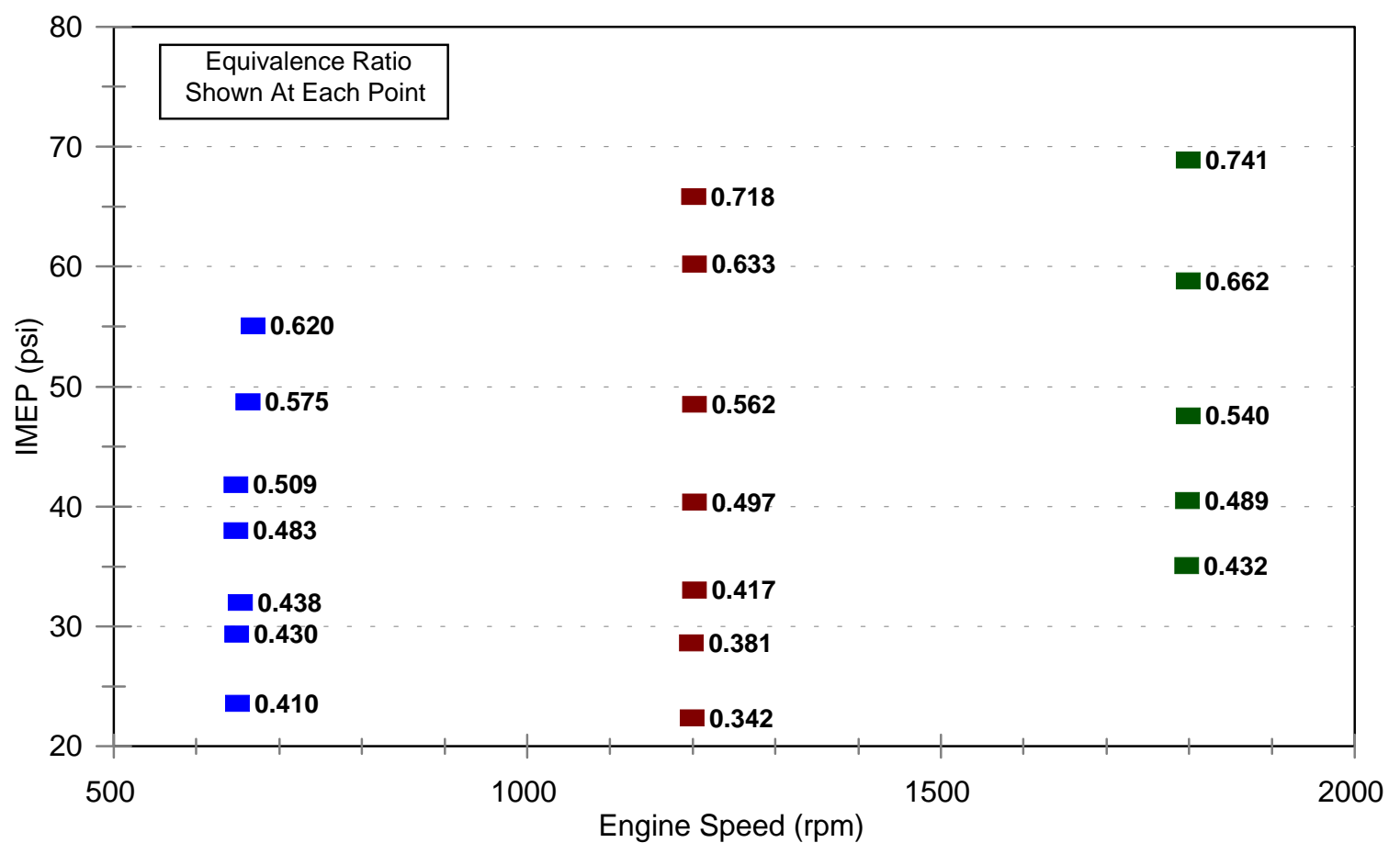

Figure 34. Plot of IMEP and equivalence ratio for each test point 


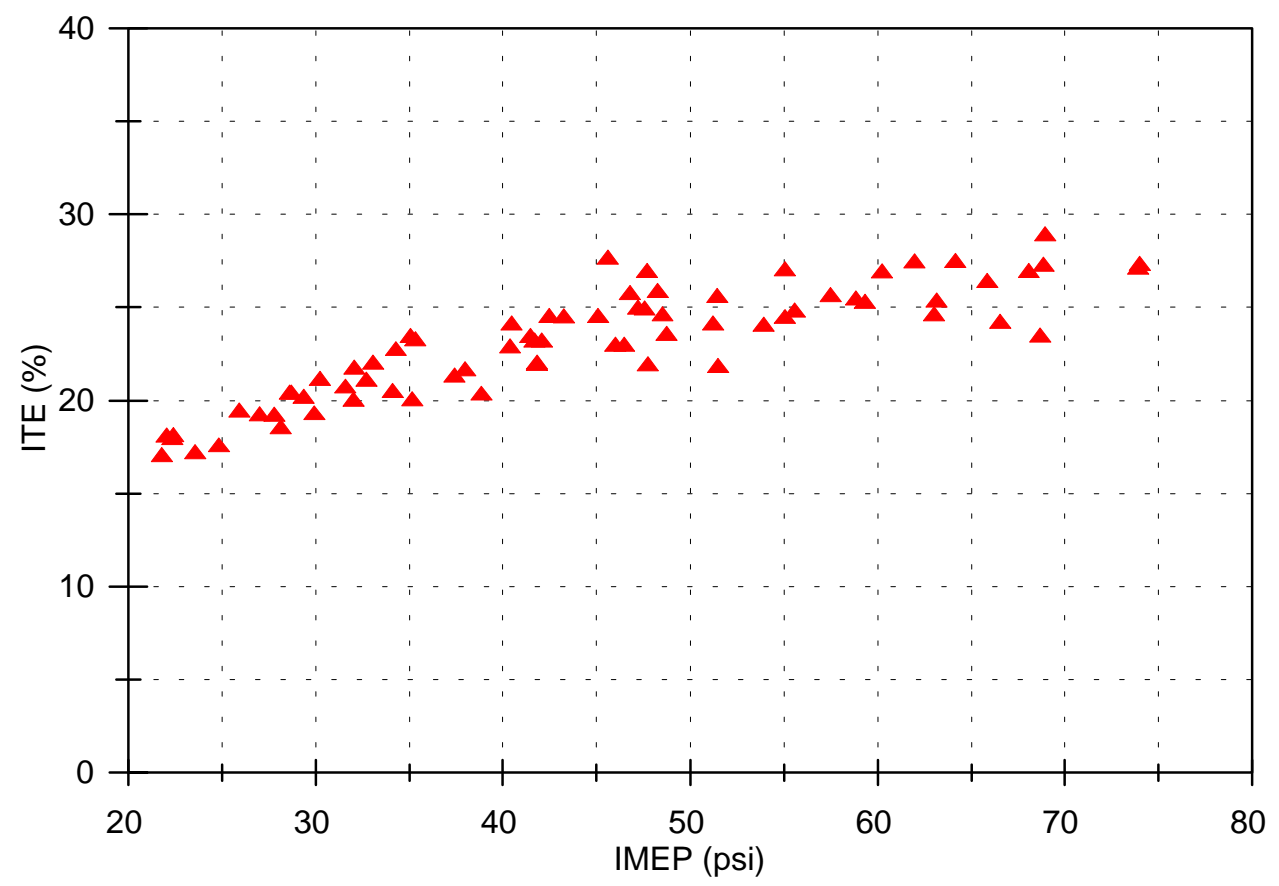

Figure 35. Indicated thermal efficiency versus indicated mean effective pressure for all data

Indicated efficiency rather than brake efficiency was used in the analysis of the data because of the difficulty in identifying the brake power contribution of the individual test cylinder compared to the other five cylinders. ITE was defined as the ratio of the work produced by the cylinder to the energy content of the total fuel flow. The ITE for these data points ranged from 15 to 30 percent. These values were reasonable for engines at light loads. Also, since the engine was operating throttleless, little work was lost via pumping. To illustrate the effects of pumping losses, a low load point at idle speed was selected from the baseline data set taken with the engine from the NREL school bus project. This engine was shown to have very good efficiency compared to existing gas engines. The indicated efficiency obtained from each mode of combustion was analyzed. Table 3 contains a comparison between the results from the two combustion modes.

Table 3. Efficiency comparison between combustion modes at idle

\begin{tabular}{|c|c|c|c|c|c||}
\hline Mode & $\begin{array}{c}\text { Gross IHP } \\
(\mathbf{h p})\end{array}$ & $\begin{array}{c}\text { Net IHP } \\
\text { (hp) }\end{array}$ & $\begin{array}{c}\text { Fuel Flow } \\
(\mathbf{l b} / \mathbf{h r})\end{array}$ & $\begin{array}{c}\text { Gross ITE } \\
(\mathbf{\%})\end{array}$ & $\begin{array}{c}\text { Net ITE } \\
(\mathbf{\%})\end{array}$ \\
\hline Stratified Charge & 1.78 & 1.84 & 1.404 & 15.8 & 16.4 \\
\hline Homogeneous Charge & 1.59 & 1.01 & 0.835 & 23.7 & 15.0 \\
\hline
\end{tabular}


The ITE values discussed previously should be referred to as gross ITE, since they do not include the contribution of the pumping work to the cycle. A similar term, net ITE, can be defined which does include the effect of pumping on the cycle. Note that the gross ITE of the stratified charge engine was lower than the homogeneous charge engine. This indicates that the stratified charge combustion process was not as efficient as the homogeneous combustion process. However, due to the large amount of negative pumping work suffered by the homogeneous charge engine, the net ITE was slightly lower than that of the stratified charge engine. Assuming the mechanical efficiency of the engine remains constant between the two modes, the brake thermal efficiency of the stratified charge engine would be higher than the homogeneous charge engine. As gains in combustion efficiency are made, the stratified charge engine's advantage in efficiency should continue to increase.

One reason for the relatively low gross ITE values was due to the combustion phasing problem. Advanced spark timing was found to be required in order to ensure adequate combustion stability. These advanced spark timings caused the combustion event to occur too early in the cycle. This aspect of the combustion process is evident in Figure 36, which shows the two combustion events as a function of equivalence ratio: the start of combustion (SOC) and the end of combustion (EOC). The spark advance (SA) relative to TDC is also shown. SOC is defined as the point at which 10 percent of the fuel burned in the cycle has been consumed. Similarly, EOC is defined at the point at which 90 percent has been consumed. Note that it took approximately 6 crank angle degrees for combustion to get established; this indicated that a relatively rich mixture surrounds the spark plug since ignition delays are typically much longer in lean burn, homogeneous charge engines. Also, note that the SOC was insensitive to equivalence ratio changes. The salient point of this plot, however, is to note that under most conditions the combustion process was completed prior to top dead center (EOC < 180). A combustion process that releases its energy prior to TDC is inefficient, since some of its energy is wasted in counteracting the upward motion of the piston. Efficiency gains would be realized by shifting the location of the combustion event to after TDC.

Figure 36 also reveals other information regarding the combustion process. For any given equivalence ratio, the combustion duration was relatively constant regardless of the spark timing. This indicated that the combustion was being confined by the combustion bowl, and was not affected by changes in swirl motion, turbulence level, etc. as the combustion event changes location. Also, the plot shows that the bowl must have been somewhat lean even at relatively high overall equivalence ratios, since the combustion duration decreased until an overall equivalence ratio of 0.5 was exceeded. Since the combustion bowl was about 34 percent of the total volume, this indicated that a large amount of fuel must have been leaving the bowl before combustion took place, otherwise the combustion bowl's equivalence ratio would have been in the range of 1.0 to 1.5. If all of the fuel remained in the combustion bowl, as the overall equivalence ratio was increased from 0.34 to 0.5 , the combustion duration should have decreased as the combustion bowl became richer locally.

The emissions characteristics for the engine are shown in Figure 37. This plot describes the $\mathrm{NO}_{\mathrm{x}} \mathrm{vs}$. $\mathrm{HC}$ tradeoff for the test cylinder. Both $\mathrm{NO}_{\mathrm{x}}$ and $\mathrm{HC}$ were quite high compared to a homogeneous charge engine. For current engines at light loads, $\mathrm{NO}_{\mathrm{x}}$ levels are typically well below $5 \mathrm{~g} / \mathrm{bhp}-\mathrm{hr}$, and $\mathrm{HC}$ emissions are usually less than $20 \mathrm{~g} / \mathrm{bhp}$-hr, with HC emissions usually dropping to well under $10 \mathrm{~g} / \mathrm{bhp}$-hr as load increases. 


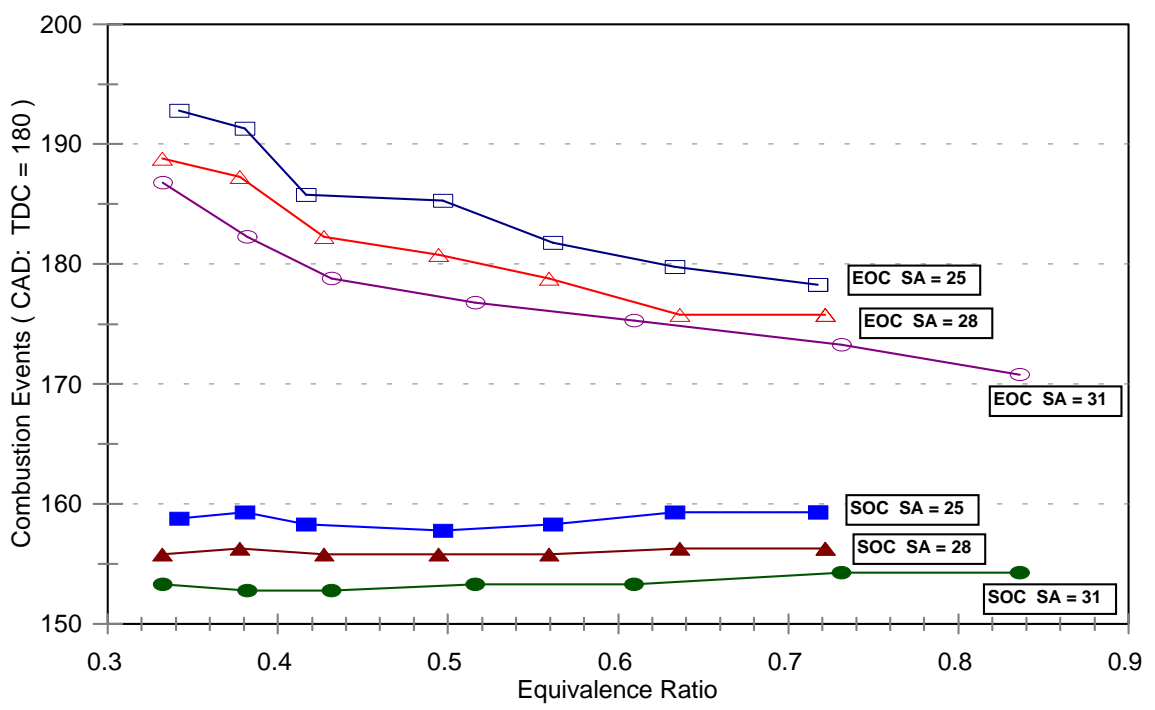

Figure 36. Combustion event timings for various spark timings and equivalence ratios at $1200 \mathrm{RPM}$

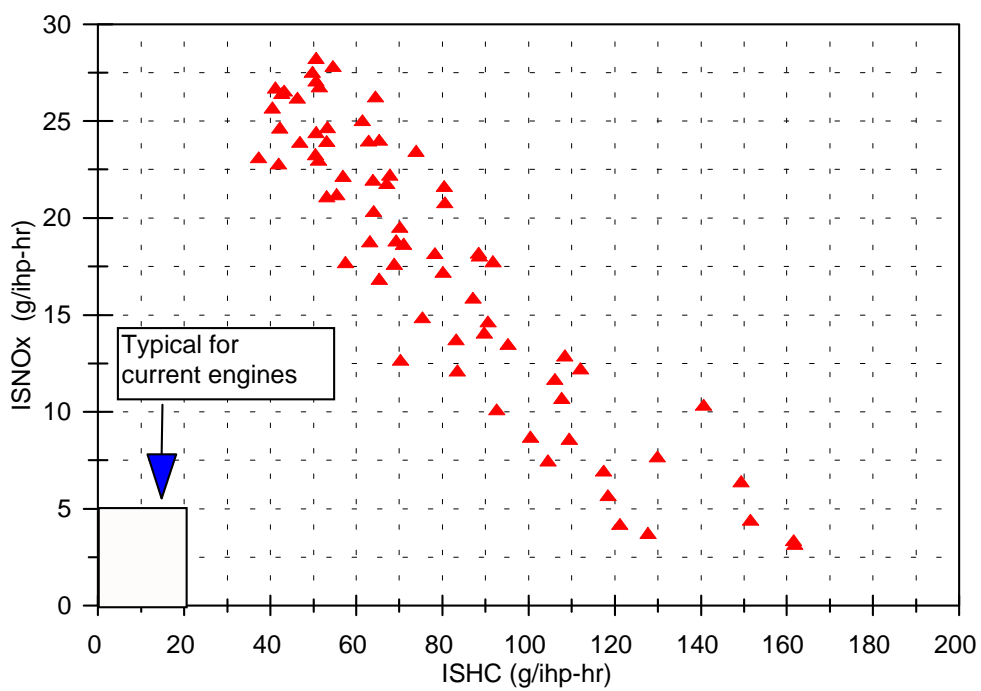

Figure 37. $\mathrm{NO}_{\mathrm{x}}$ vs. $\mathrm{HC}$ tradeoff characteristic for the stratified charge engine. Data obtained at test conditions defined in Table 2. 
It is clear from this plot that simultaneous reductions must be made in $\mathrm{NO}_{\mathrm{x}}$ and $\mathrm{HC}$ emissions. Further improvements in combustion control must be made in order to achieve these reductions. The ability to control combustion in this engine requires the ability to control both the timing of the combustion process and the placement of the fuel in the combustion chamber.

As discussed, the combustion process was being substantially completed before top dead center. For $\mathrm{NO}_{\mathrm{x}}$ control, the obvious course of action would be to retard the spark timing in order to change the phasing of the combustion event. However, the range of combustion control offered by spark retard was found to be limited. Figure 38, which shows plots of engine performance and emissions parameters as a function of spark timing, illustrates this limitation. This particular data was taken at $1200 \mathrm{rpm}$ and the end of injection and equivalence ratio setpoints were held constant. As can be seen from the plots, as spark timing was reduced, a point was reached where the performance of the combustion system deteriorated considerably. For example, at a spark timing of 28 degrees, ITE dropped significantly, and the misfire percentage also increased significantly. Also, the hydrocarbon emissions steadily increased as spark timing was retarded from 34 to 25 degrees. It is also interesting to note that although the main purpose of retarding the spark timing was to change the combustion phasing, the average angle at which peak cylinder pressure occurred was retarded by only 1 crank angle degree (from 180.3 to 181.3) as the spark timing was retarded by 9 crank angle degrees.

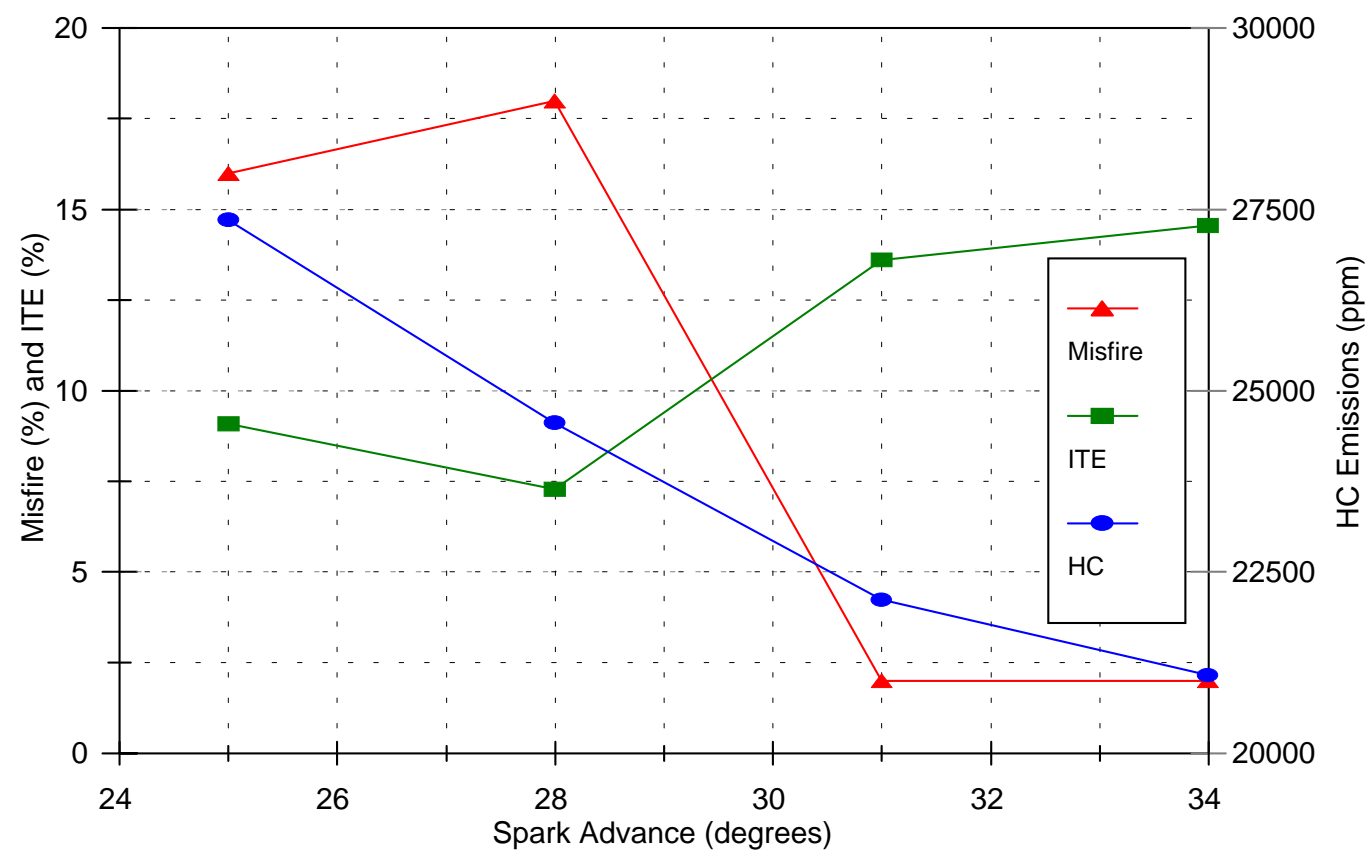

Figure 38. Plot of ITE, misfire percentage, and HC emissions as a function of spark timing. Data obtained at $1200 \mathrm{rpm}$, constant end of injection timing and equivalence ratio setpoints 
The high unburned $\mathrm{HC}$ emissions were most likely due to the fuel gas being swept out of the combustion bowl and into the main piston bowl by the air swirl motion. In this case, the fuel-air mixture in the main bowl would be overly diluted, and the fuel would not be consumed by combustion. This hypothesis is based on the behavior shown in Figure 39, which shows the percentage of the total fuel flow that was unburned. The percentage is calculated from measurements of the total fuel flow and the exhaust HC emissions. At lean equivalence ratios, a considerable fraction of the total fuel flow was emitted from the combustion chamber without taking part in the combustion process. If this fraction could be reduced substantially, the HC emissions would be much lower.

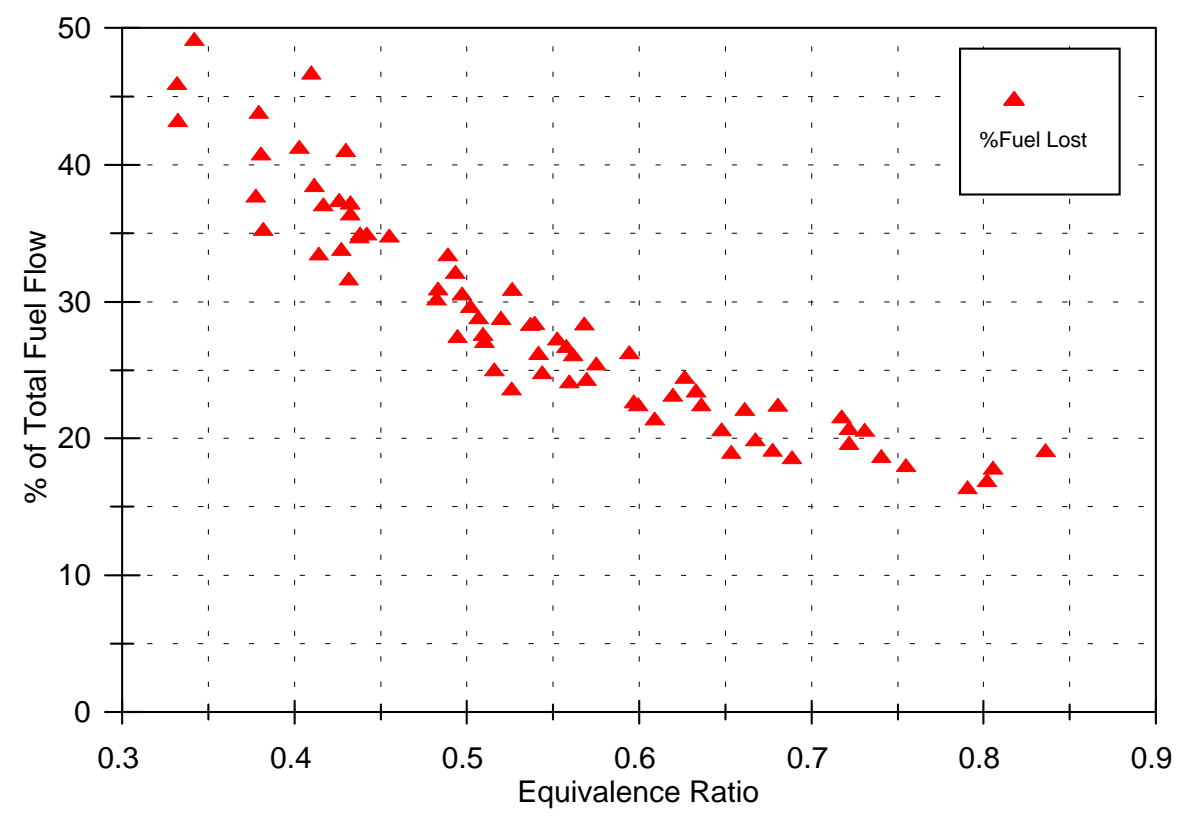

Figure 39. Percentage of total fuel flow unburned and lost by the combustion chamber

\section{Increased Injection Pressure Investigation}

A short series of experiments were conducted to try to determine the optimum injection pressure for stratified charge combustion. Tests were run at three injection pressures: 550 psia, 750 psia, and $950 \mathrm{psia}$. All of the tests were conducted at $1200 \mathrm{rpm}$. The end of injection timing was fixed at 58 degrees BTDC, and the equivalence ratio setpoint was held constant. The injection system and engine were able to operate satisfactorily at all three pressures. In terms of emissions and performance, $750 \mathrm{psia}$ was found to be the best operating pressure. Figure 40 is a plot of the $\mathrm{NO}_{\mathrm{x}}$ - efficiency tradeoff, in terms of $\mathrm{ISNO}_{\mathrm{x}}$ and ITE. Note that the curve representing the data obtained at a 750 psia injection pressure has the best $\mathrm{ISNO}_{\mathrm{x}}$ versus ITE tradeoff. 
Injection Pressure Experiments

NOx vs. Efficiency Results

$1200 \mathrm{rpm}, \mathrm{EOI}=58^{\circ} \mathrm{BTDC}$, Variable SA, Avg. $\phi=0.466$

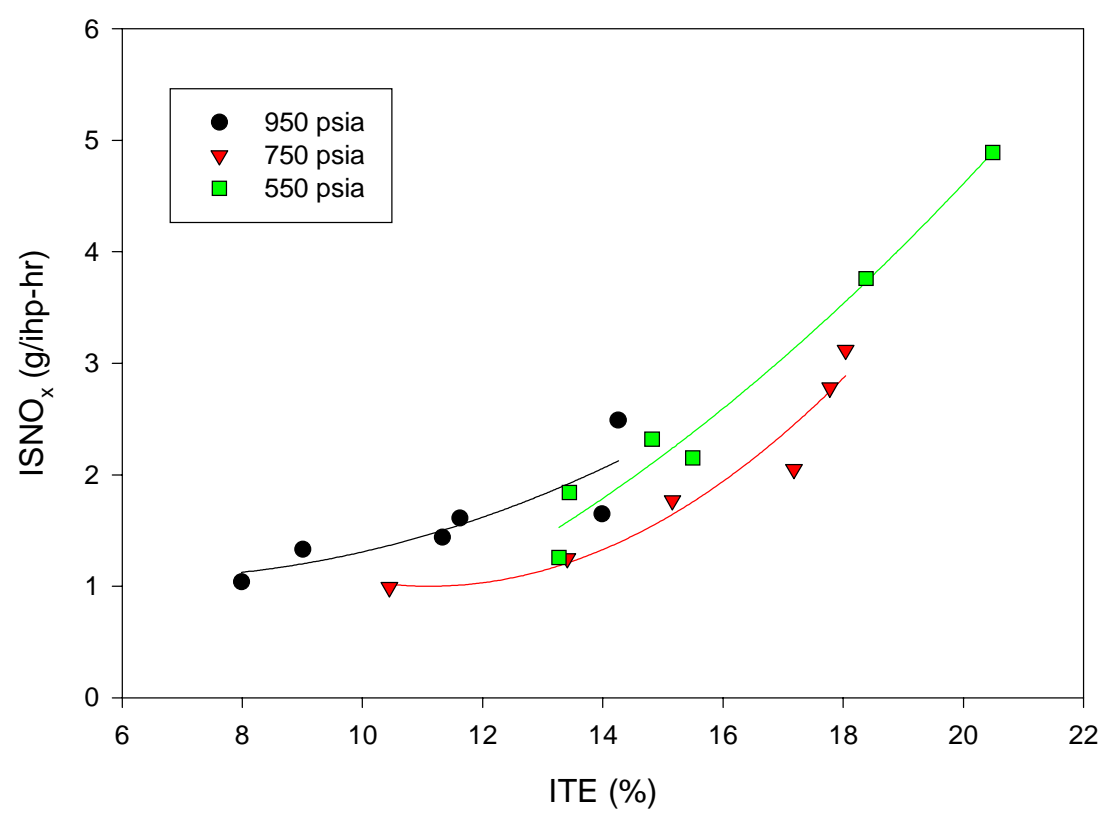

Figure 40. $\mathrm{NO}_{\mathrm{x}}$ efficiency tradeoff as a function of injection pressure

\section{Hybrid Homogeneous Charge/Stratified Charge Experiments}

In order to achieve the full operating range of the engine, transitions between stratified charge and homogeneous charge combustion would need to occur. In addition, enhancements beyond the traditional homogeneous charge combustion mode could increase engine performance at medium to high load operating conditions. With this in mind, experimental testing of a hybrid combustion mode was conducted. The hybrid combustion mode comprised a premixed homogeneous charge introduced into the cylinder and augmented with a late cycle direct fuel injection. The main purpose of the hybrid combustion mode was to facilitate the transition region between the stratified charge combustion mode and the homogeneous charge combustion mode. The hybrid combustion mode could also be used in place of the homogeneous combustion mode at medium to high load conditions if this was found to be advantageous.

To investigate this hybrid injection strategy, a port fuel injector was added to the intake runner of the test cylinder. The amount of premixed fuel and direct-injected fuel could be varied by changing the relative pulsewidths of each injector, while maintaining the overall fuel flow. For these tests, the engine was operated at $1200 \mathrm{rpm}$, and the spark timing, end of injection timing, and equivalence ratio setpoints were held constant. A series of runs, with increasingly higher fractions of premixed fuel, was undertaken, and the results are shown in Figure 41. 


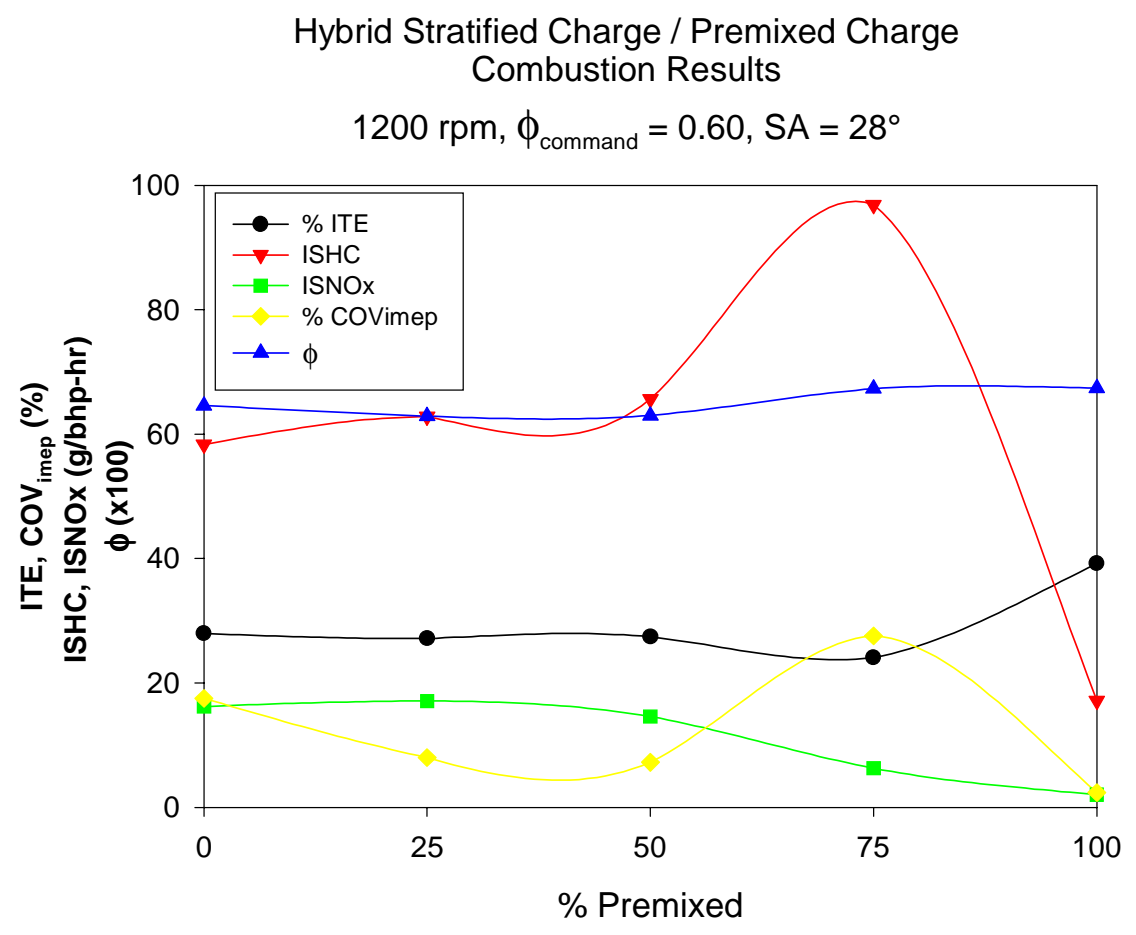

Figure 41. Results of hybrid injection strategy testing

Note that the best performance and emissions characteristics are obtained with a 100 percent premixed fuel charge, i.e. a homogeneous charge mode. Operation with direct injection only, or 0 percent premixed fuel, had higher emissions and lower efficiency, as expected from previous test results. An improvement in combustion stability, as measured by a decrease in the coefficient of variation in the indicated mean effective pressure (COVimep) was found when the premixed fuel was in the range of 25-50 percent. Also in the region, the $\mathrm{ISNO}_{x}$, ISHC, and ITE all remained relatively constant. However, at a premixed percentage of 75 percent, both the COVimep and ISHC increase greatly, indicating that the combustion quality has deteriorated. This may be due to the main combustion bowl becoming overly rich, which would reduce combustion stability and increase unburned hydrocarbon emissions. The dip in ITE at this point also lends support to the idea that the mixture becomes overly rich at these conditions.

The results do confirm that a hybrid strategy can be used, within limits, for the transition between stratified charge and homogeneous charge modes. Use of a split injection, e.g. one injection very early in the intake stroke and one late in the compression stroke, would likely be the most practical way to implement this hybrid fueling strategy. This would eliminate the need for a secondary port fuel injection system. Improvements in injector technology would be needed, however. 


\section{Turbocharger Subsystem Experiments}

As the final part of the Experimental Program, two different boost control subsystems were evaluated for determination of the most suitable approach for this unique engine concept. The first approach was similar to the production engine configuration and utilized a modified wastegated turbocharger concept. The second approach, felt to be best suited to this engine concept, was utilizing a variable geometry turbocharger (VGT). Each boost control subsystem was evaluated on the engine with three basic performance criteria: steady-state efficiency, low-level boost modulation capability, and transient response. The results of the study are contained in the following subsections of this report.

\section{Enhanced Wastegate Evaluation}

A study of the steady-state and transient performance of the engine equipped with a modified wastegated turbocharger was conducted for the purpose of determining the most suitable turbocharger configuration and boost control methodology for the engine. The production Deere $8.1 \mathrm{~L}$ gas engine was equipped with a wastegated turbocharger, however it was felt that the production configuration of the turbocharger would not be adequate for the throttleless SI engine concept being developed. The level of air handling system control required for this engine concept is unique for several reasons. First, since the final engine concept is to be throttleless but have load modulation (from roughly 30 percent to 100 percent load) remain controlled by air flow, the boost control subsystem must provide desirable transient response performance characteristics, i.e., fast and stable boost response. Furthermore, since the turbocharger will be the only means for load control in the homogeneous charge combustion mode, accurate boost control at low boost levels (i.e., less than 3 setpsig) will be required even at high engine speed. Given the air handling system requirements described previously, and underscoring the fact that the traditional load control device on the engine (i.e., the throttle) will be removed, SwRI investigated modifications to the wastegated turbocharger configuration. These modifications are discussed in more detail in the following paragraphs.

Three primary modifications were made to a production wastegated turbocharger as part of this work. The first change was that shop air was used as the means of actuating the wastegate in lieu of air pressure from the turbocharger compressor. This approach should not present a problem in a vehicular application since each engine is equipped with an air compressor. Using this approach, the position of the wastegate actuator could be controlled at all operating conditions. This technique was successfully demonstrated during the NREL school bus project.

The second modification was enlargement of the wastegate holes in the turbine housing that determine the maximum wastegate flow area. The maximum wastegate flow area of the modified housing was increased to roughly 150 percent of the production configuration. The increased flow area allowed boost pressure to be kept at low levels during high speed engine operation. This was not possible with the production configuration.

The third modification was to change the wastegate actuator assembly to achieve a longer lever arm between the linear movement of the wastegate actuator and the rotational movement of the wastegate valves within the turbine housing. Through analysis of the wastegate valve rotational angle versus effective flow angle geometry, it was determined that the production wastegate valve/actuator achieved full-closed to effectively full-open position over roughly $1 / 4$ inch of linear actuator travel. The maximum linear travel of the wastegate actuator was roughly $5 / 8$ inches. Therefore, very small actuator position changes were required to achieve adequate boost control. Furthermore, this meant that only about 40 percent of the linear actuator travel was useful in affecting the wastegate area, and in turn controlling boost. Based on this analysis, SwRI designed and fabricated an actuator assembly which allowed easy adjustment of the critical lever arm length. The assembly, as mounted on the turbocharger is shown in Figure 42. The assembly was adjusted such that the 
full 5/8 inches of linear travel was used in achieving the full-closed to full-open wastegate positions. The modified actuator was found to provide increased levels of boost control stability with no degradation in transient response.

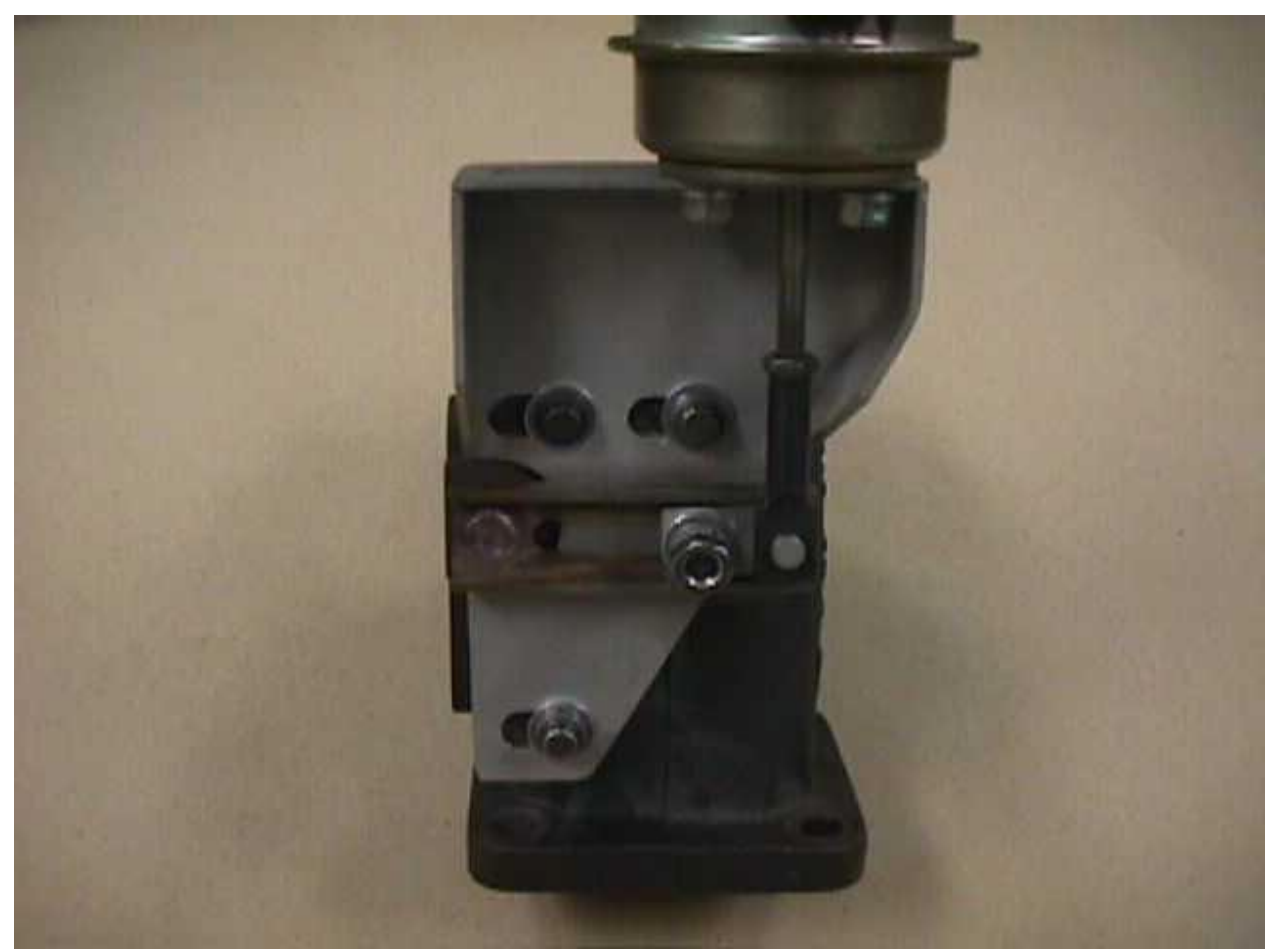

Figure 42. Modified wastegate actuator for enhanced wastegate evaluation

\section{Variable Geometry Turbocharger Evaluation}

In order to identify the best means of meeting the air handling system requirements for the engine, a variable geometry turbocharger (VGT) was evaluated in the same manner as the enhanced wastegated turbocharger discussed previously. The VGT for the project was a VNT40 (or variable nozzle turbine) and was developed by Allied Signal. A photograph of the VNT40 is shown in Figure 43. The VGT worked by varying the angle of vanes within the turbine housing which vector the exhaust toward the turbine wheel. By changing the vane angle, via a pneumatic linear actuator functionally similar to a wastegate actuator, boost pressure could be controlled to the desired level. A photograph of the moveable vanes within the VNT40 is shown in Figure 44. 


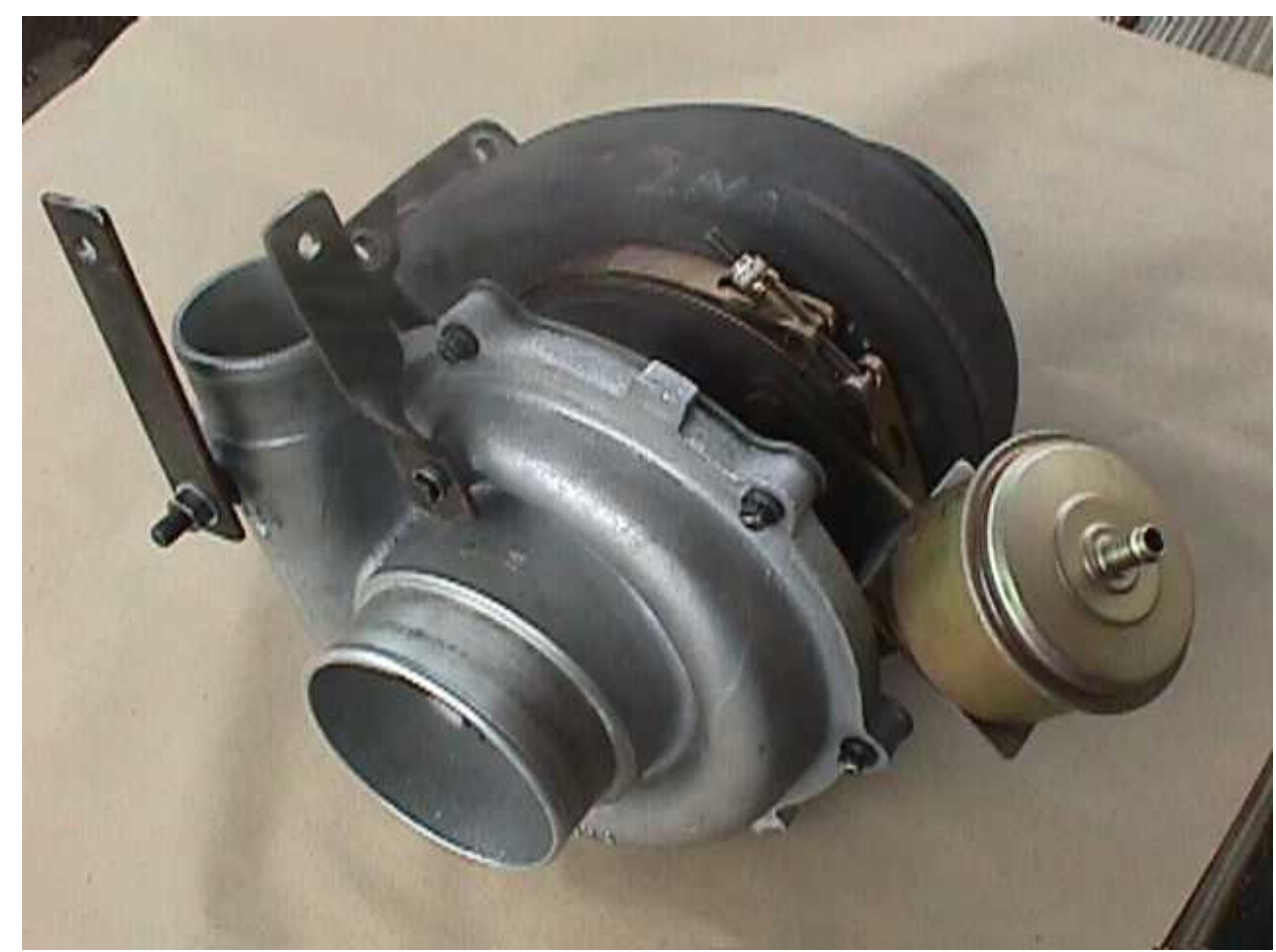

Figure 43. Variable geometry turbocharger (VNT40)

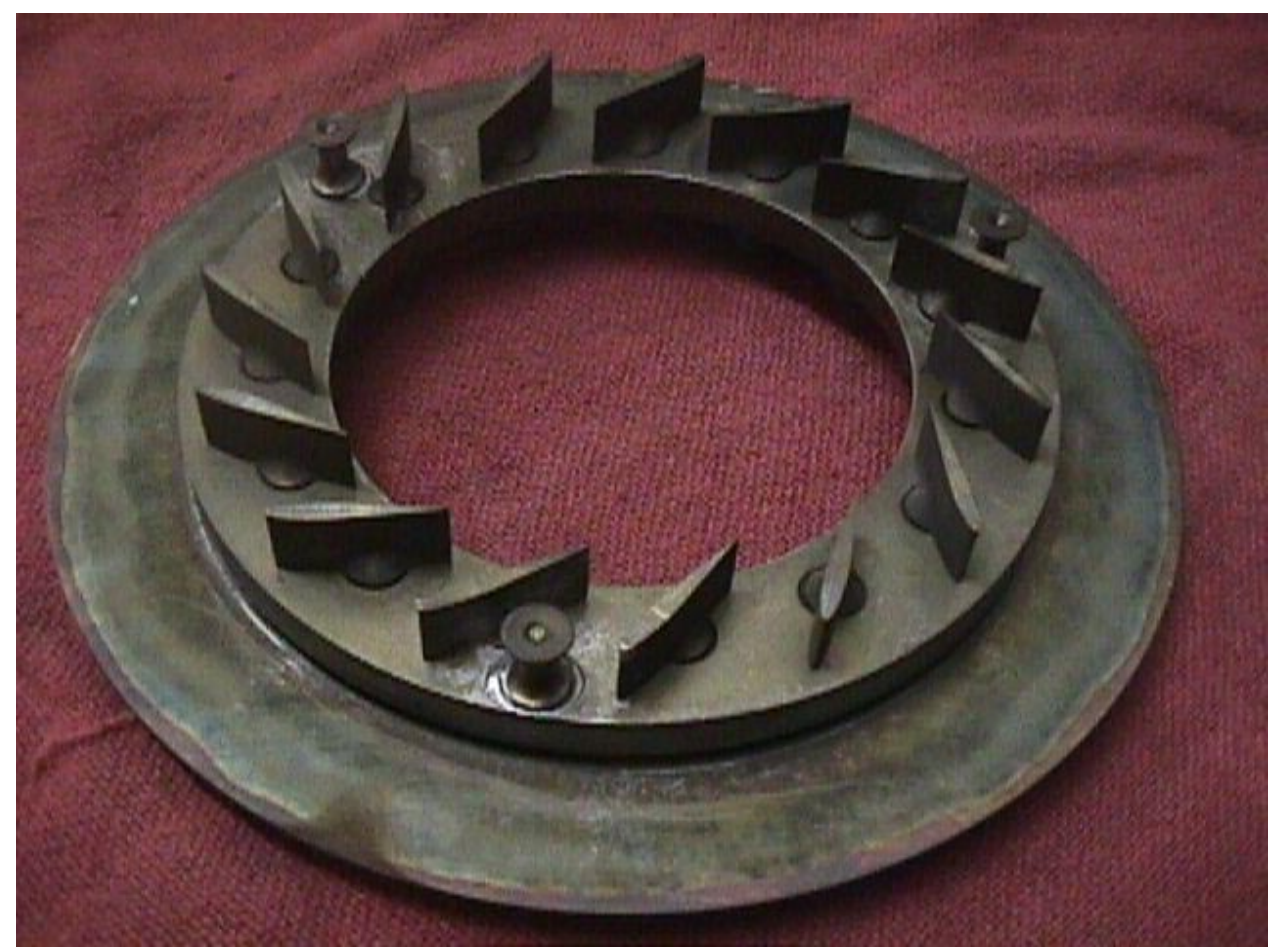

Figure 44. Internal view of VNT40 variable nozzle vanes 
In addition to the functional differences of the VNT40 versus the wastegated turbocharger, the pneumatic actuation requirements were also somewhat different. The pneumatic actuator used on the VNT40 required considerably more air pressure than the wastegate actuator to achieve its full range of motion. Roughly 35 psig was required to achieve full motion of the VNT40 actuator, whereas about 15 psig was required for the wastegate actuator. In addition, the volume of the actuator canister was significantly larger for the VNT40 than for the wastegated turbocharger. Also, air pressure was supplied to the VNT40 actuator in order to achieve higher boost conditions. This was opposite the wastegate actuator where air pressure was supplied to the actuator in order to open the wastegate and hence reduce boost. Given these differences in actuation requirements, a modified pneumatic control valve arrangement was developed. The modified arrangement included a Bosch injector as a wastegate control valve along with an increased orifice size in order to achieve adequate actuator response and accommodate the increased air supply pressure. A comparison of the two pneumatic control valve arrangements, i.e., for the wastegated turbocharger and for the VNT40, is shown in Figures 45 and 46, respectively.

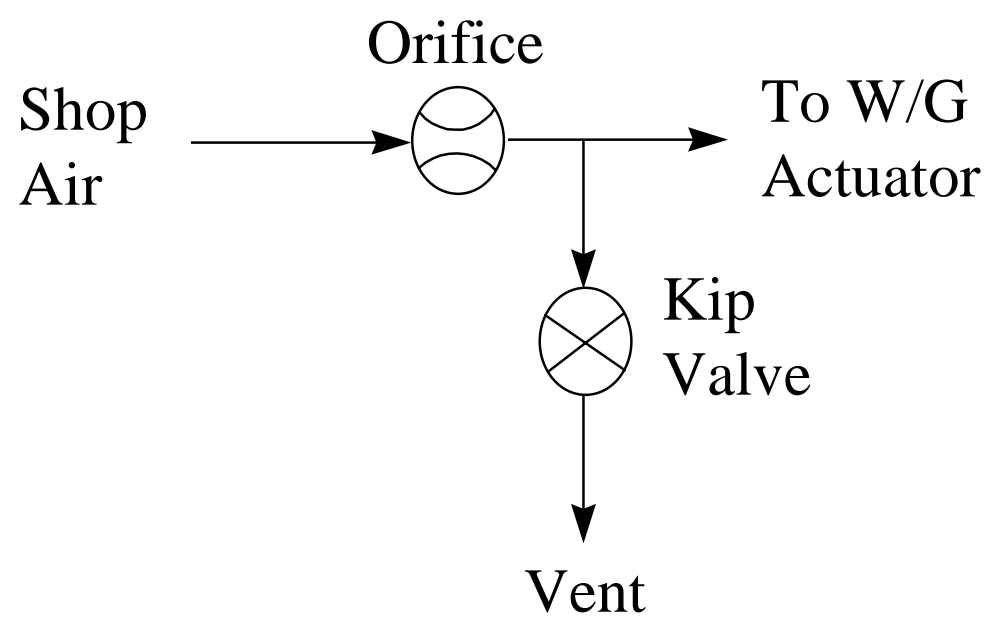

Figure 45. Wastegate pneumatic control arrangement

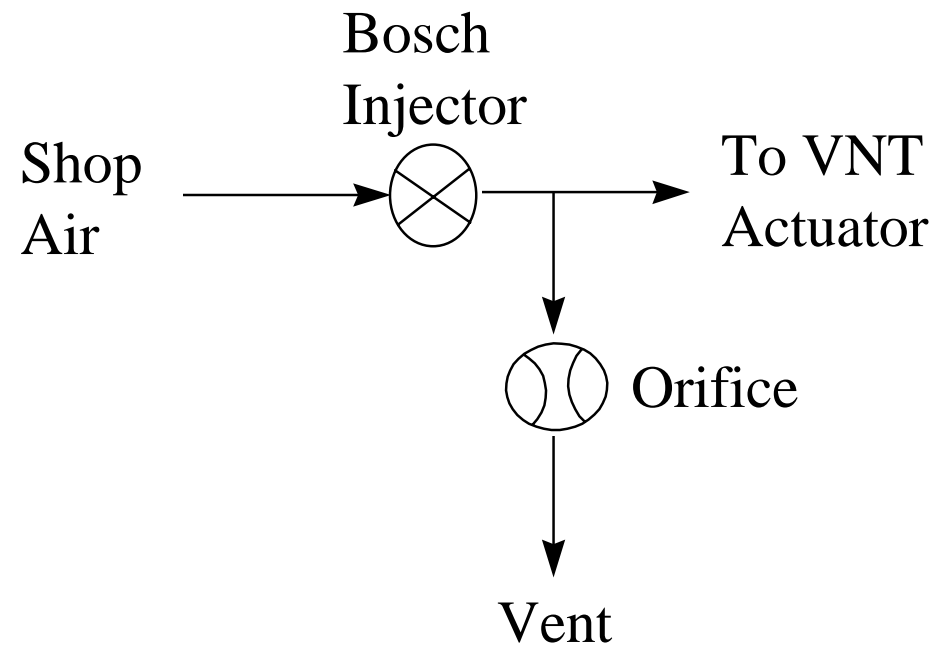

Figure 46. VNT pneumatic control arrangement 


\section{Steady-State Test Results}

Steady-state as well as step transient engine testing was performed for each turbocharger subsystem in order to quantify relative performance. Again, the objective of the evaluation was to show each subsystem's effects on engine efficiency, low-level boost control capability, and transient response. Contour plots of brake thermal efficiency as a function of engine speed and load are shown in Figures 47 and 48 for the wastegated turbocharger and VNT40, respectively. It should be noted that the steady-state data were taken at different ambient humidity levels. The enhanced wastegate data were taken at a humidity level of roughly $0.0105 \mathrm{~kg}$ water/kg air, this is representative of an "average" humidity level. The VNT40 data were taken at a humidity level of approximately $0.0140 \mathrm{~kg}$ water $/ \mathrm{kg}$ air, or a wet condition. If both approaches were equivalent, the enhanced wastegate data would achieve an efficiency level roughly 3 percent (i.e., about 1 BTE point) higher than the VNT40 data due to the humidity effect alone.

\section{Enhanced Wastegate-Equipped 8.1L Engine Thermal Efficiency Contour Map}

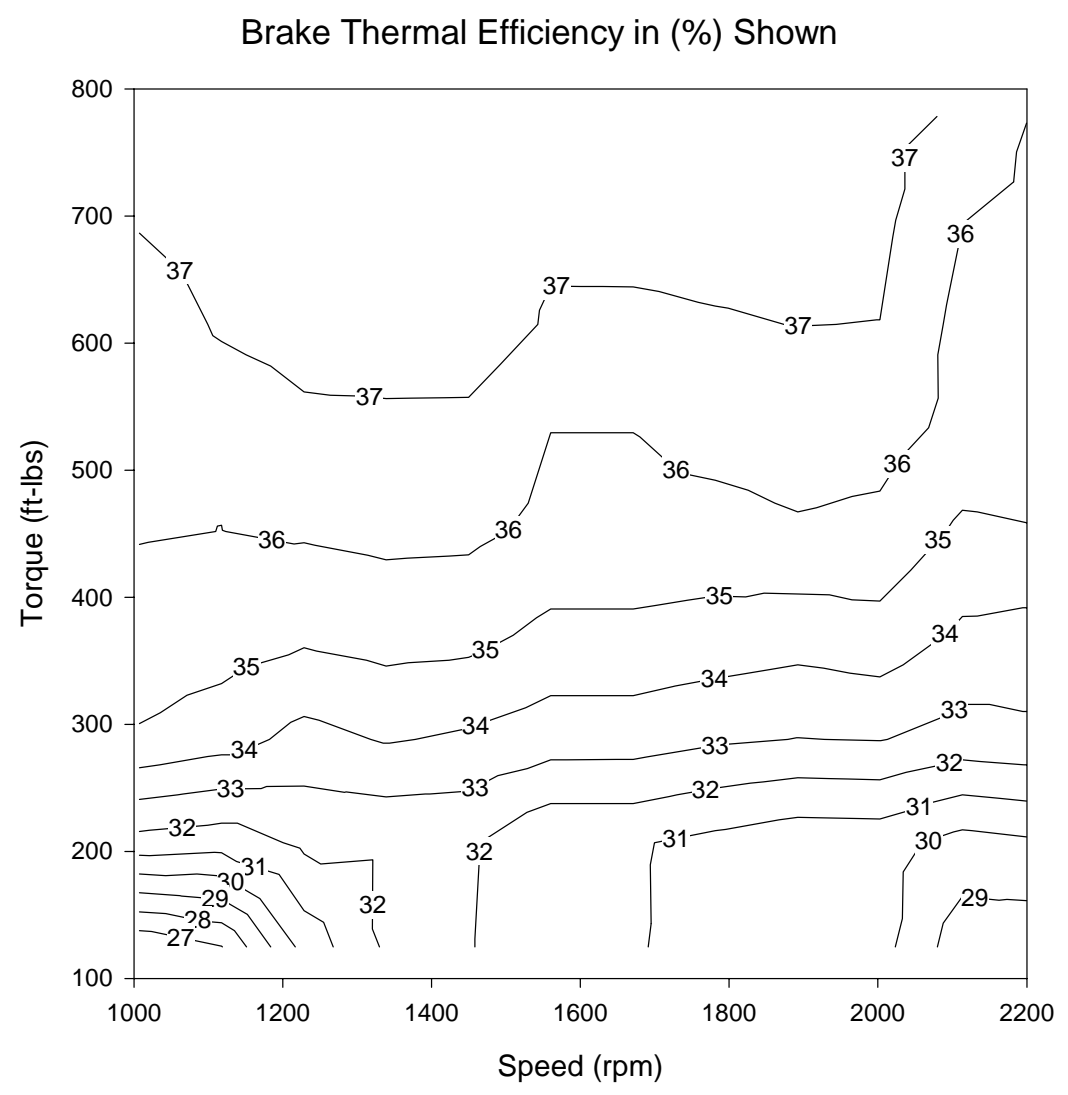

Figure 47. Thermal efficiency map for enhanced wastegate engine 


\section{VNT-Equipped 8.1L Engine \\ Thermal Efficiency Contour Map}

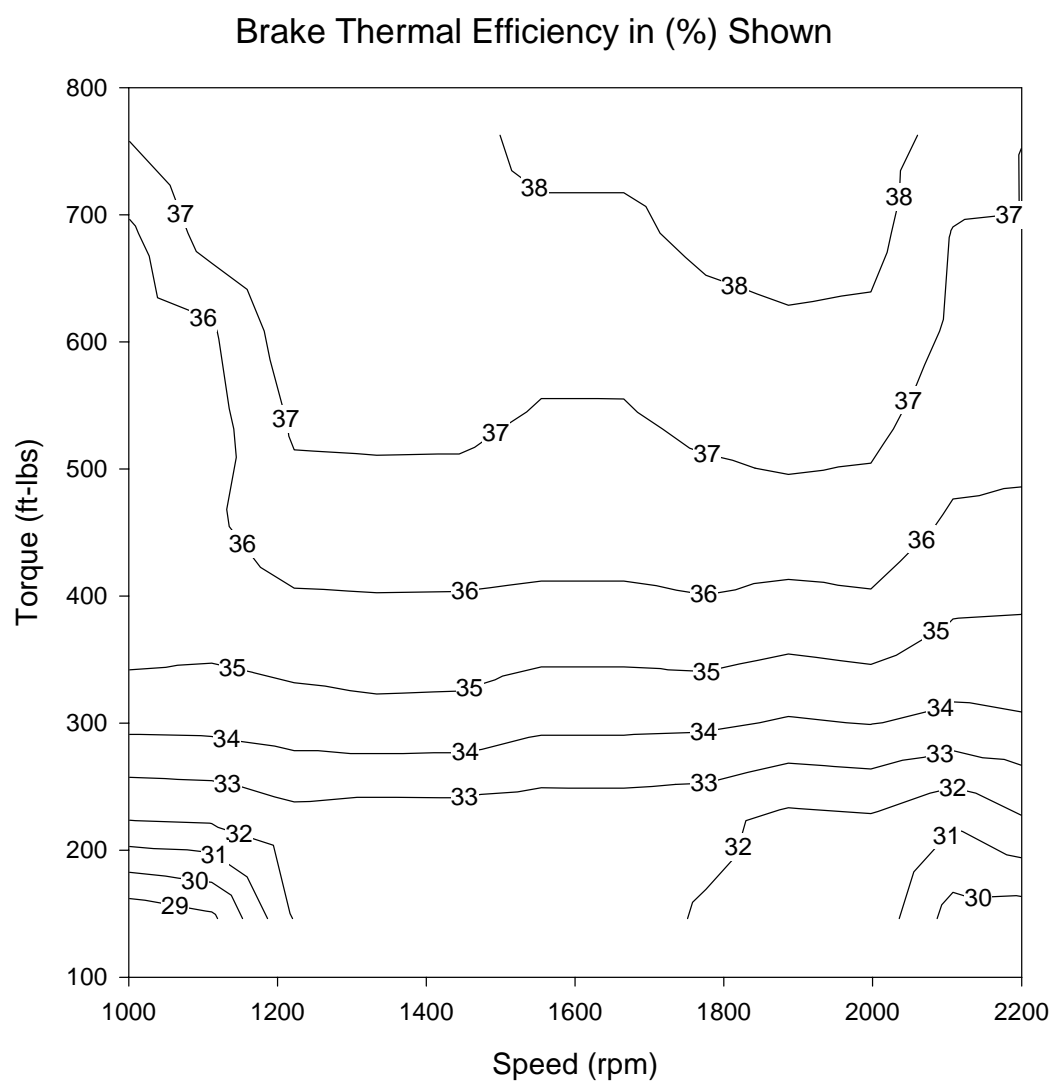

Figure 48. Thermal efficiency map for VNT engine

As can be seen from the data, efficiency at low engine speeds (around $1000 \mathrm{rpm}$ ) was slightly better with the wastegated turbocharger. Again, the difference was relatively small and could be attributed to the difference in ambient humidity. However, as engine speed was increased through $1350 \mathrm{rpm}$ and above, there was a significant reversal in the trend. At $2200 \mathrm{rpm}$, the data taken with the VNT40 indicated a full thermal efficiency point increase at essentially all load conditions. Thus, if all the engine data were taken at the same humidity level, further efficiency increases (on the order of an additional thermal efficiency point) would have been observed in the VNT40 data. The significant efficiency increases observed with the VNT40 were larger than expected. These increases can largely be explained by the data in the following paragraph.

Figures 49 and 50 show contour plots of the pressure drop across the cylinder head (i.e., intake manifold pressure minus exhaust manifold pressure) as a function of engine speed and load for the enhanced wastegated turbocharger and VNT40, respectively. A positive pressure difference indicates intake manifold pressure greater than exhaust manifold pressure, or a favorable condition. Conversely, a negative value indicates an unfavorable pressure difference across the cylinder head. Negative pressure differences have an unfavorable effect on engine efficiency and emissions, and increase the fuel-air equivalence ratio at which the engine's lean misfire limit is achieved. Negative pressure differences impact these parameters because of an increase in pumping work and an increase in residual fraction. As the figures show, higher positive 
pressure differences were achieved at low speed, high load operating conditions with the wastegated turbocharger. However, as engine speed was increased, this trend was reversed and became significantly in favor of the VNT40 near the rated speed of $2200 \mathrm{rpm}$. At the rated power point for the engine, i.e., $250 \mathrm{bhp}$ at $2200 \mathrm{rpm}$, the pressure difference was $3.7 \mathrm{psi}$ with the VNT40 and was -1.2 psi with the wastegated turbocharger. As can also be seen from the data, the characteristic curve shapes for the VNT40 were significantly different than those of a fixed geometry turbine, i.e., the wastegated turbocharger. The curves remained essentially flat as a function of engine speed, except for low engine speeds. The reason for this was that the VNT40 had more control authority to behave like a smaller turbine at low engine speeds and allowed more boost pressure to be achieved at low engine speeds than the wastegated turbocharger. The wastegated turbocharger acted much more like a fixed restriction or orifice in the exhaust.

\section{Enhanced Wastegate-Equipped 8.1L Engine Pressure Differential Across Cylinder Head Contour Map}

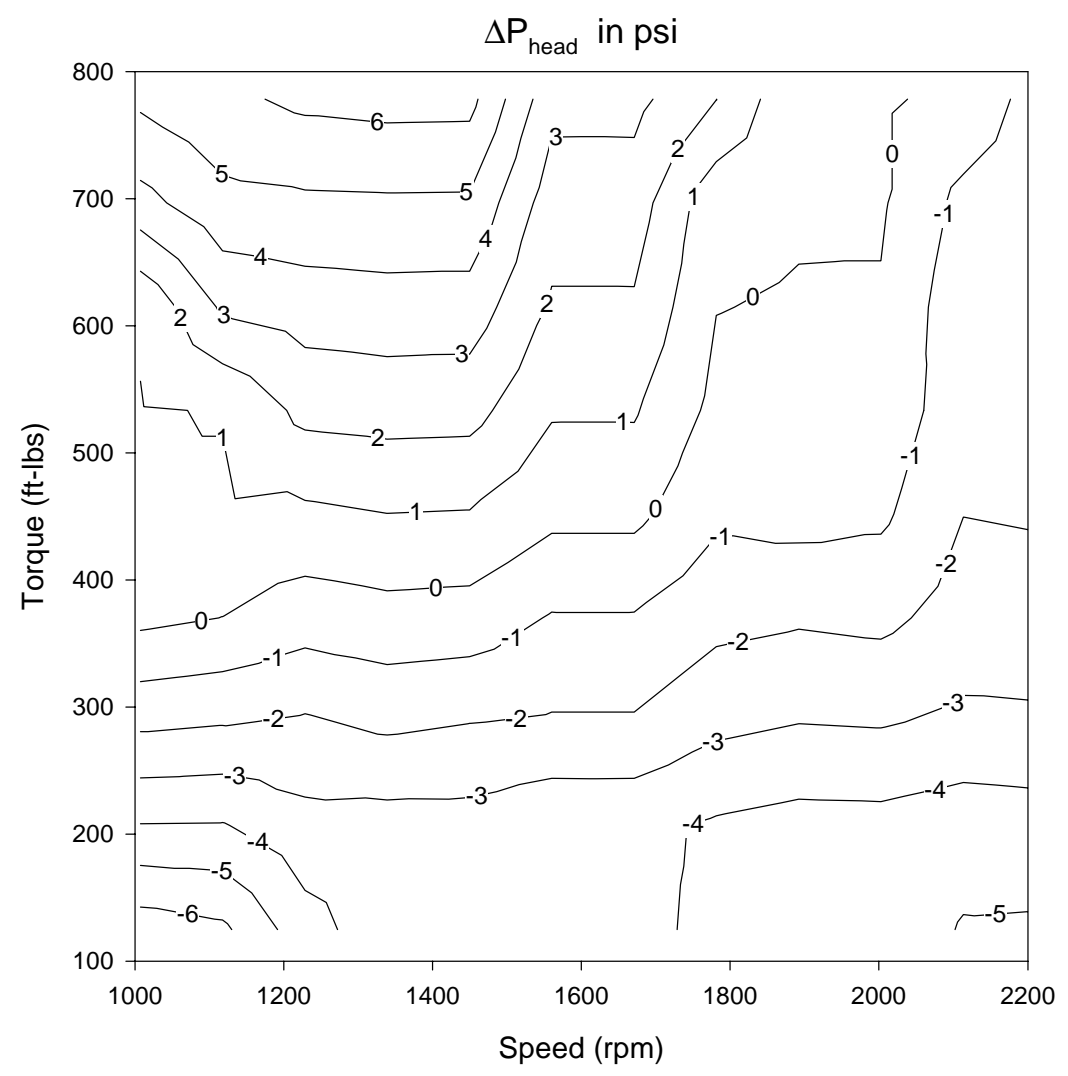

Figure 49. Cylinder head pressure differential map for enhanced wastegate engine 


\section{VNT-Equipped 8.1L Engine \\ Pressure Differential Across Cylinder Head \\ Contour Map}

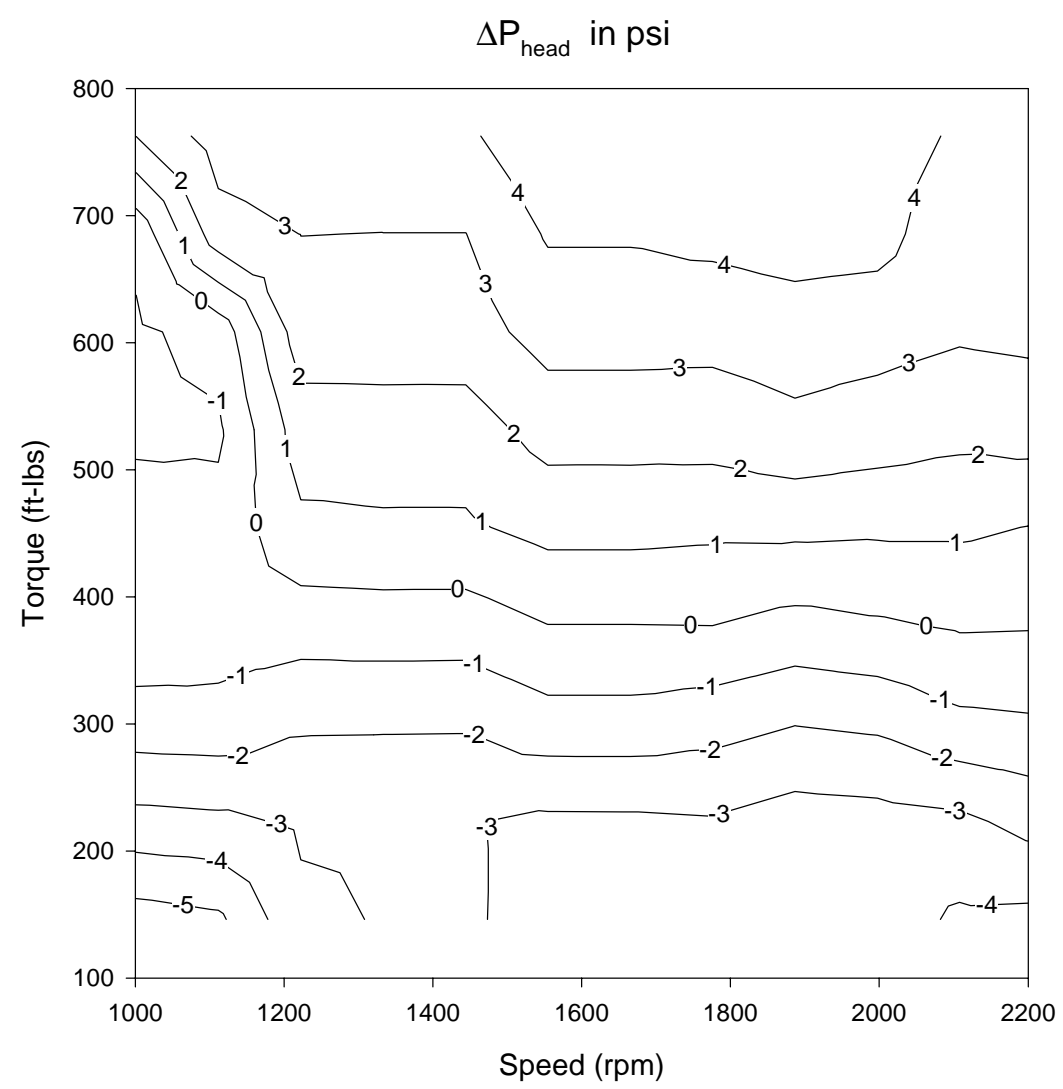

Figure 50. Cylinder head pressure differential map for VNT40 engine

Contour plots of the pressure loss across the throttle as a function of engine speed and load are shown for the wastegated turbocharger and the VNT40 in Figures 51 and 52, respectively. These data show the turbochargers' ability to maintain low values of pressure loss across the throttle, and hence low levels of boost pressure at light load conditions. The data also shows the portion of the operating range where minimal throttling was used. As can be seen from the data, the engine was operated essentially unthrottled (i.e., less than 3 psi pressure drop) over most of the operating range (i.e., over about the $250 \mathrm{ft}$-lb torque level). The figures also show the portion of the operating range over which the stratified charge combustion strategy must be utilized in order to run the engine in a throttleless mode (i.e., below the $250 \mathrm{ft}-1 \mathrm{~b}$ torque level). It is anticipated that the $250 \mathrm{ft}-\mathrm{lb}$ torque level will define the upper limit of a transition region between the stratified charge and homogeneous charge combustion modes. Also note that both the wastegated turbocharger and the VNT40 performed quite similarly in terms of the ability to achieve low levels of boost during high speed operation in order to keep the pressure drop across the throttle to a minimum. 


\section{Enhanced Wastegate-Equipped 8.1L Engine \\ Pressure Differential Across Throttle}

Contour Map

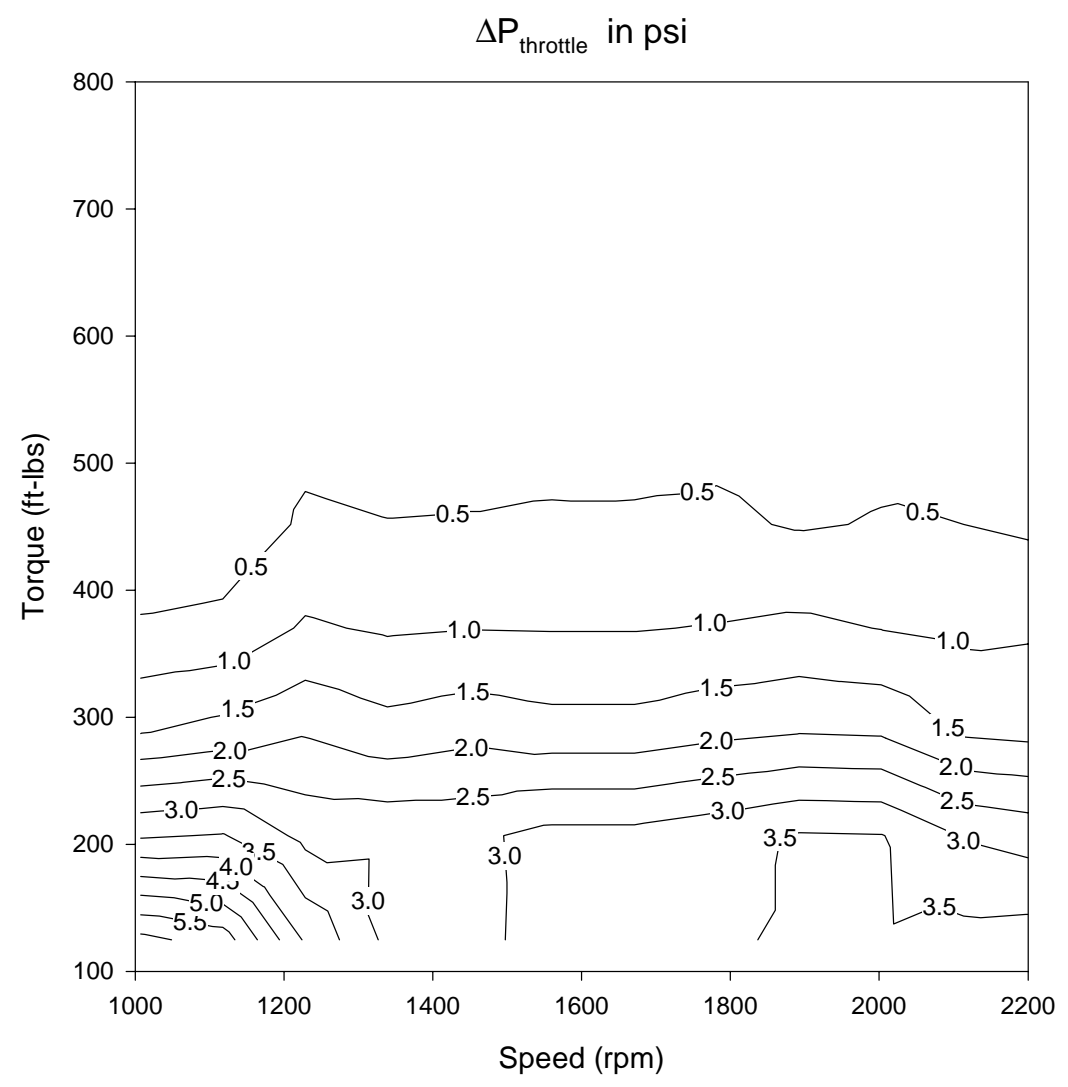

Figure 51. Throttle pressure differential map for enhanced wastegate engine 


\section{VNT-Equipped 8.1L Engine \\ Pressure Differential Across Throttle \\ Contour Map}

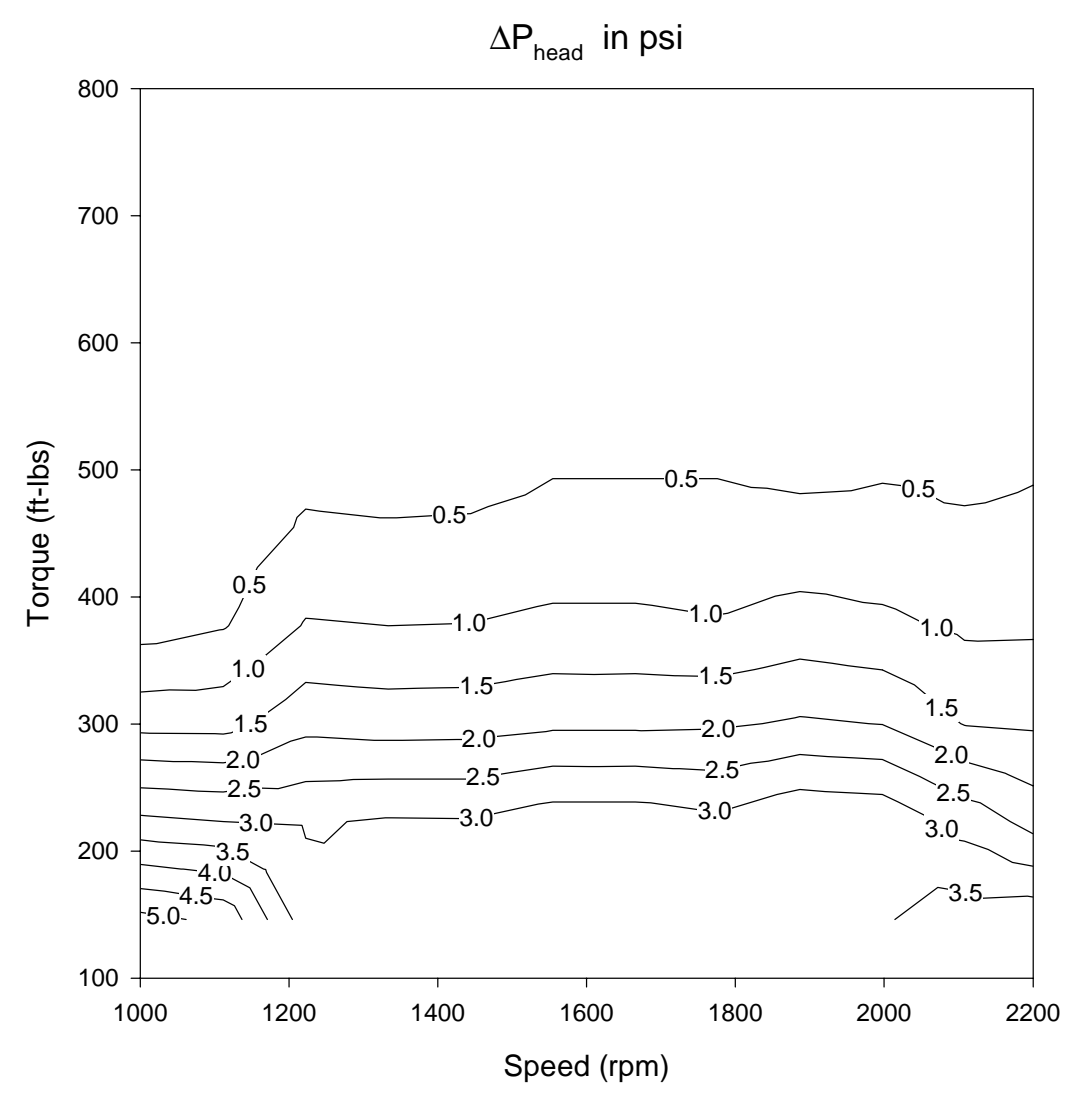

Figure 52. Throttle pressure differential for VNT engine

\section{Step Transient Results}

The transient response of both turbocharger subsystems was compared under throttle step response test conditions. The objective of these transient tests was to show the relative performance of the two turbochargers in terms of their ability to increase or decrease boost pressure at various operating conditions. Again, since the final engine concept is anticipated to operate in a traditional homogeneous charge combustion mode over most of the operating map, the transient torque response of the engine will be dictated by the boost response of the turbocharger. If the wastegated turbocharger response is considered acceptable in terms of boost response time, the VNT40 was expected to have similar, or faster response times in order to also be considered acceptable.

A matrix of step throttle transient tests was performed for each turbocharger configuration. Independent variables for the test matrix were the initial engine speed and load conditions, the maximum throttle for the step transient, and enabling or disabling of the turbocharger lag compensation within the engine control system. Turbocharger lag compensation consisted of temporary enrichment of the fuel-air mixture coupled with spark retard for the purposes of enhancing the spool-up performance of the turbocharger during a load pickup transient. Typical transient performance of the enhanced wastegated turbocharger with and without 
turbocharger lag compensation is shown in Figure 53 and 54, respectively. Similarly, transient performance of the VNT40 is shown in Figure 55 and 56, respectively. The plots show the commanded and actual prethrottle (or boost) pressure (PTPCmd and PTP, respectively), the throttle position command, the desired fuelair equivalence ratio (PhiCmd), and the fuel-air equivalence ratio measured by the universal exhaust gas oxygen sensor (UEGO_Phi). The transients shown in the figures were performed at $1600 \mathrm{rpm}$ at a 30 percent load initial condition. As shown in the figures, for each of the transients, the throttle was transitioned from the initial position to 100 percent throttle over 0.1 seconds, held at 100 percent for 10 seconds, and transitioned back to the initial position over 0.1 seconds. The boost response can be seen as the time required to achieve the desired boost level. Examining Figure 53 and Figure 55, it can be seen that boost response times were quite similar between the wastegated turbocharger and the VNT40. Tables 4, 5, and 6 are compilations of transient boost response times for each set of transient conditions at engine speeds of 1350 $\mathrm{rpm}, 1600 \mathrm{rpm}$, and $1900 \mathrm{rpm}$, respectively. As can be seen from the data, the wastegated turbocharger provided slightly faster response times than the VNT40 at $1350 \mathrm{rpm}$ using turbocharger lag compensation. As engine speed was increased, the VNT40 response times became faster than those from the wastegated turbocharger. Also, without turbocharger lag compensation, the VNT40 response times were faster than the wastegated turbocharger at all engine speeds. Thus, with the VNT40, the need for turbocharger lag compensation could potentially be reduced and any fuel consumption or emissions penalties associated with this compensation could be minimized.

\section{Enhanced Wastegate Evaluation Boost Response (1600 RPM/30\% Load)}

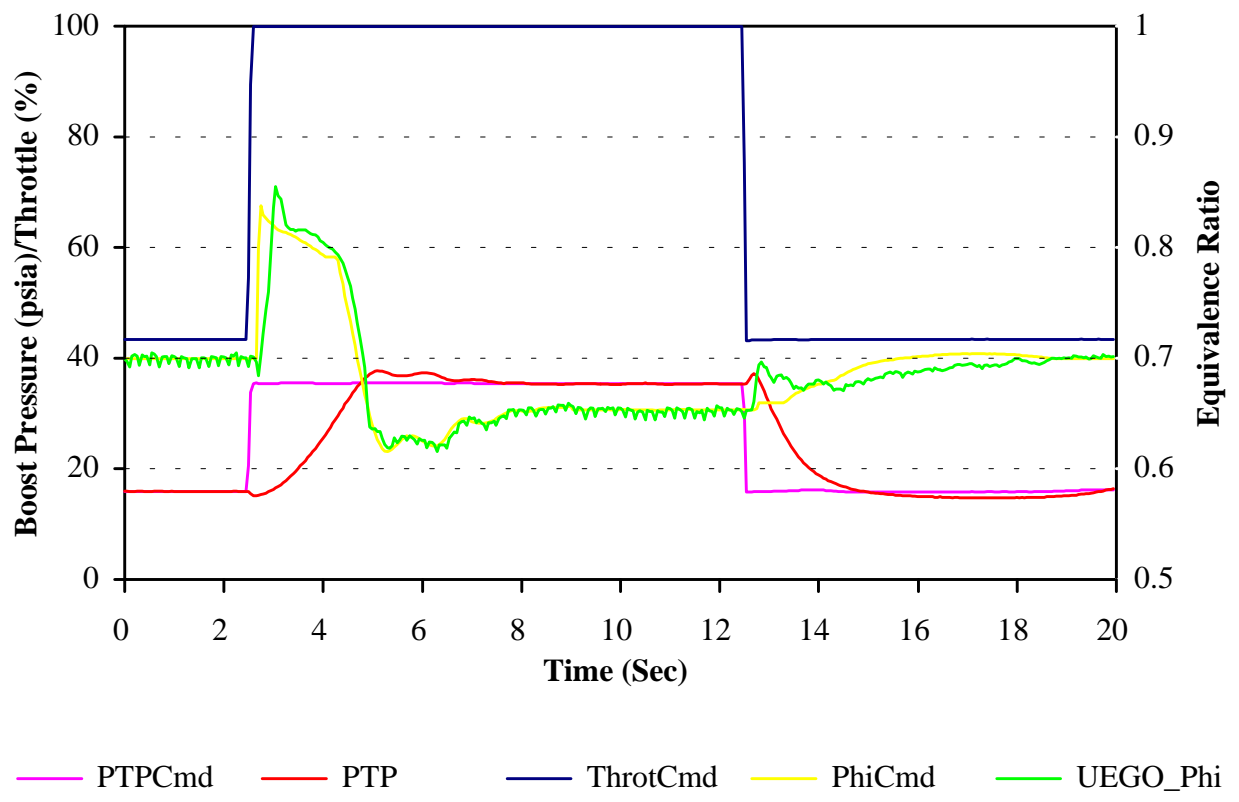

Figure 53. Wastegated turbocharger step transient with turbo lag compensation 


\section{Enhanced Wastegate Evaluation}

W/O Turbo Lag Comp (1600 RPM/30\% Load)

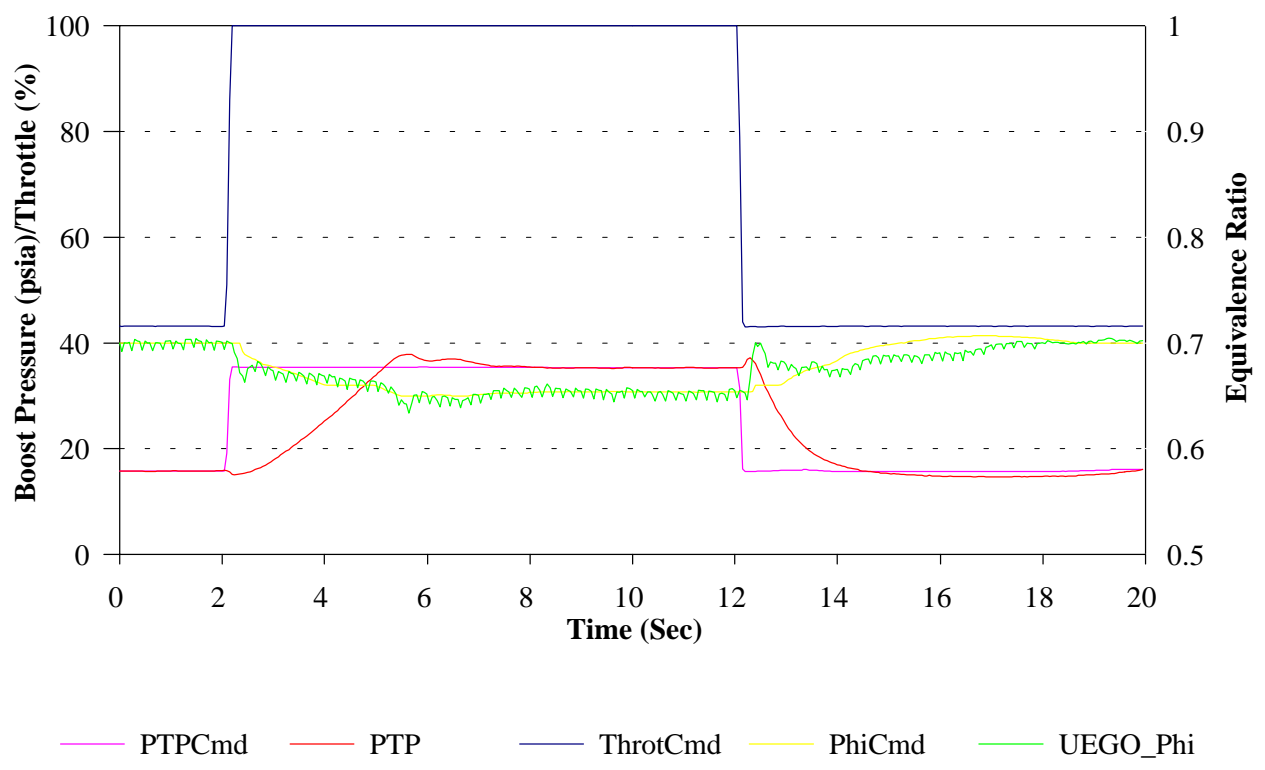

Figure 54. Wastegated turbocharger step transient without turbo lag compensation

\section{VGT Evaluation}

W/ Turbo Lag Comp (1600 RPM/30\% Load)

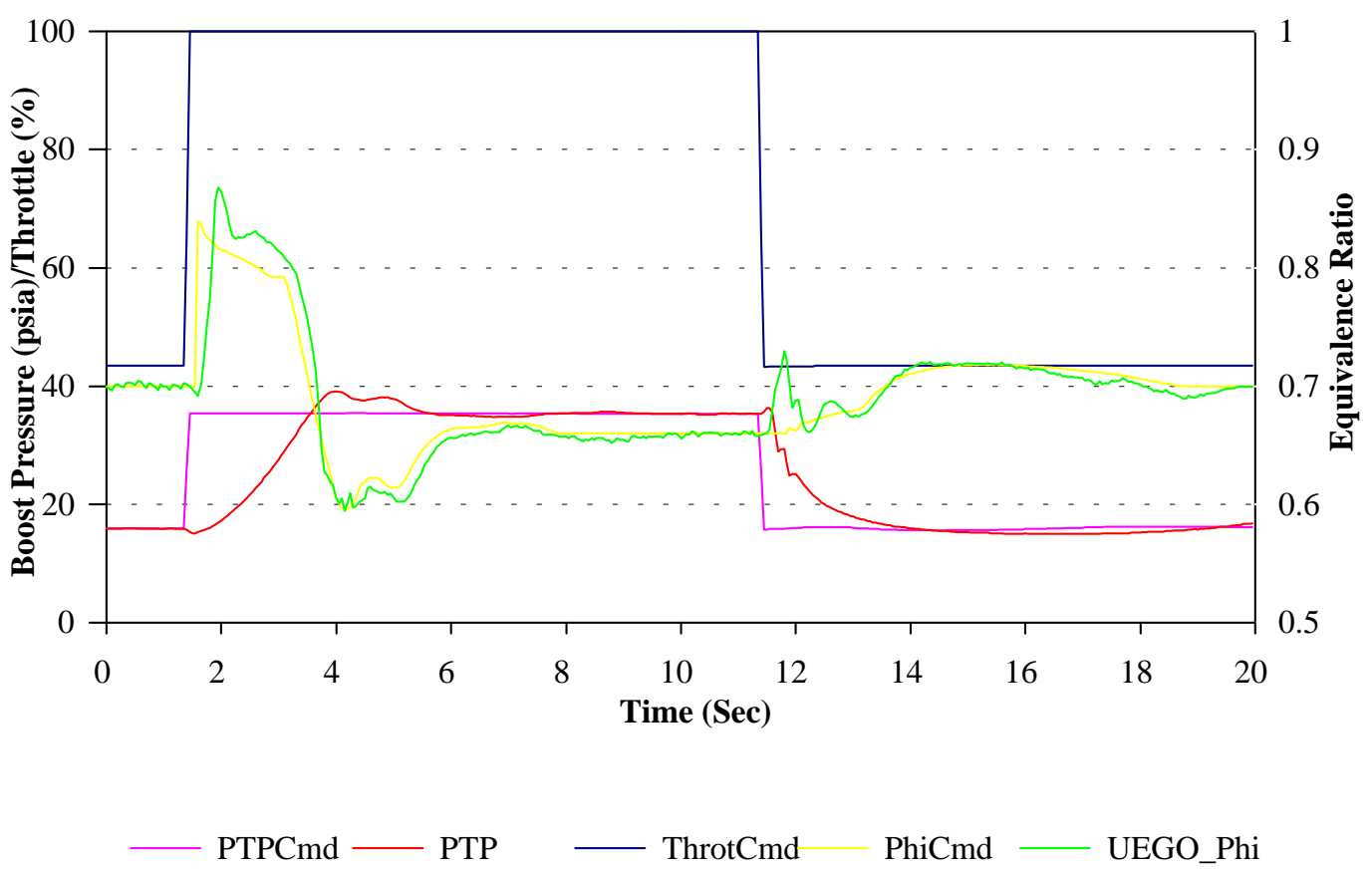

Figure 55. VNT40 step transient with turbo lag compensation 
W/O Turbo Lag Comp (1600 RPM/30\% Load)

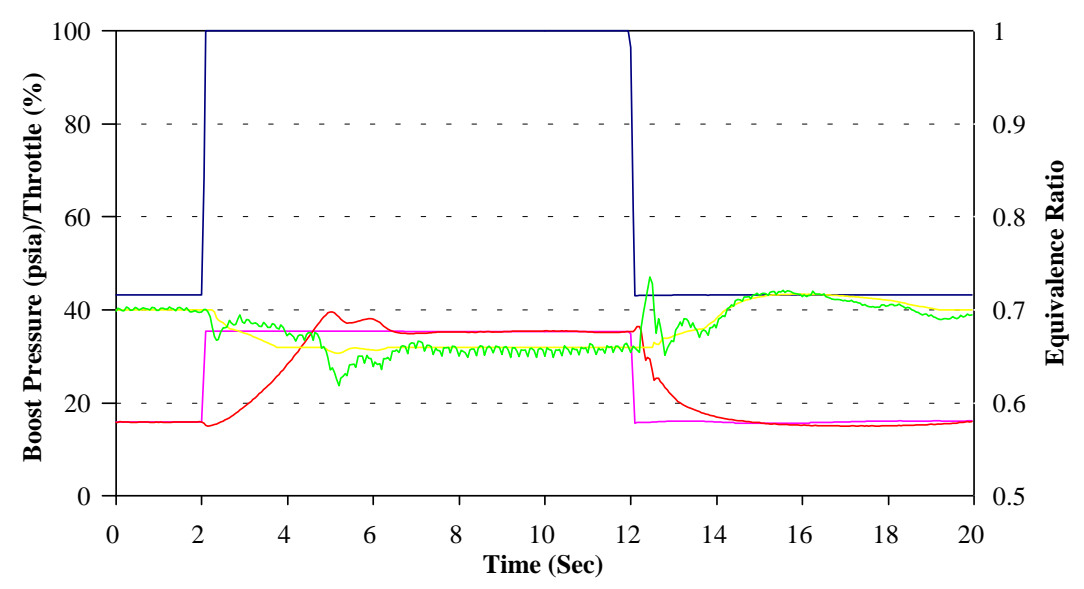

Figure 56. VNT40 step transient without Turbo lag compensation

Table 4. Boost response time comparison - 1350 rpm

\begin{tabular}{||c|c|c|c|c|c||}
\hline $\begin{array}{c}\text { Initial } \\
\text { Load }\end{array}$ & $\begin{array}{c}\text { Maximum } \\
\text { Throttle }\end{array}$ & $\begin{array}{c}\text { Enh W/G } \\
\text { Response Time } \\
\text { (w/ TLC) }\end{array}$ & $\begin{array}{c}\text { Enh W/G } \\
\text { Response Time } \\
\text { (w/out TLC) }\end{array}$ & $\begin{array}{c}\text { VNT } \\
\text { Response Time } \\
\text { (w/ TLC) }\end{array}$ & $\begin{array}{c}\text { VNT } \\
\text { Response Time } \\
\text { (w/out TLC) }\end{array}$ \\
\hline $30 \%$ & $60 \%$ & $1.75 \mathrm{sec}$ & $2.50 \mathrm{sec}$ & $2.35 \mathrm{sec}$ & $2.35 \mathrm{sec}$ \\
\hline $30 \%$ & $80 \%$ & $2.85 \mathrm{sec}$ & $4.75 \mathrm{sec}$ & $3.30 \mathrm{sec}$ & $4.0 \mathrm{sec}$ \\
\hline $30 \%$ & $100 \%$ & $3.15 \mathrm{sec}$ & $6.00 \mathrm{sec}$ & $3.65 \mathrm{sec}$ & $4.75 \mathrm{sec}$ \\
\hline $60 \%$ & $80 \%$ & $1.50 \mathrm{sec}$ & $2.95 \mathrm{sec}$ & $1.90 \mathrm{sec}$ & $2.45 \mathrm{sec}$ \\
\hline $60 \%$ & $100 \%$ & $1.85 \mathrm{sec}$ & $3.80 \mathrm{sec}$ & $2.35 \mathrm{sec}$ & $2.95 \mathrm{sec}$ \\
\hline
\end{tabular}

Table 5. Boost response time comparison - 1600 rpm

\begin{tabular}{||c|c|c|c|c|c||}
\hline $\begin{array}{c}\text { Initial } \\
\text { Load }\end{array}$ & $\begin{array}{c}\text { Maximum } \\
\text { Throttle }\end{array}$ & $\begin{array}{c}\text { Enh W/G } \\
\text { Response Time } \\
\text { (w/ TLC) }\end{array}$ & $\begin{array}{c}\text { Enh W/G } \\
\text { Response Time } \\
\text { (w/out TLC) }\end{array}$ & $\begin{array}{c}\text { VNT } \\
\text { Response Time } \\
\text { (w/ TLC) }\end{array}$ & $\begin{array}{c}\text { VNT } \\
\text { Response Time } \\
\text { (w/out TLC) }\end{array}$ \\
\hline $30 \%$ & $60 \%$ & $1.35 \mathrm{sec}$ & $1.70 \mathrm{sec}$ & $1.35 \mathrm{sec}$ & $1.45 \mathrm{sec}$ \\
\hline $30 \%$ & $80 \%$ & $1.95 \mathrm{sec}$ & $2.75 \mathrm{sec}$ & $1.95 \mathrm{sec}$ & $2.25 \mathrm{sec}$ \\
\hline $30 \%$ & $100 \%$ & $2.25 \mathrm{sec}$ & $3.10 \mathrm{sec}$ & $2.15 \mathrm{sec}$ & $2.55 \mathrm{sec}$ \\
\hline $60 \%$ & $80 \%$ & $1.10 \mathrm{sec}$ & $1.50 \mathrm{sec}$ & $1.10 \mathrm{sec}$ & $1.30 \mathrm{sec}$ \\
\hline $60 \%$ & $100 \%$ & $1.30 \mathrm{sec}$ & $1.80 \mathrm{sec}$ & $1.30 \mathrm{sec}$ & $1.55 \mathrm{sec}$ \\
\hline
\end{tabular}


Table 6. Boost response time comparison - 1900 rpm

\begin{tabular}{||c|c|c|c|c|c||}
\hline $\begin{array}{c}\text { Initial } \\
\text { Load }\end{array}$ & $\begin{array}{c}\text { Maximum } \\
\text { Throttle }\end{array}$ & $\begin{array}{c}\text { Enh W/G } \\
\text { Response Time } \\
\text { (w/ TLC) }\end{array}$ & $\begin{array}{c}\text { Enh W/G } \\
\text { Response Time } \\
\text { (w/out TLC) }\end{array}$ & $\begin{array}{c}\text { VNT } \\
\text { Response Time } \\
\text { (w/ TLC) }\end{array}$ & $\begin{array}{c}\text { VNT } \\
\text { Response Time } \\
\text { (w/out TLC) }\end{array}$ \\
\hline $30 \%$ & $60 \%$ & $1.45 \mathrm{sec}$ & $1.45 \mathrm{sec}$ & $1.15 \mathrm{sec}$ & $1.15 \mathrm{sec}$ \\
\hline $30 \%$ & $80 \%$ & $2.00 \mathrm{sec}$ & $2.05 \mathrm{sec}$ & $1.55 \mathrm{sec}$ & $1.55 \mathrm{sec}$ \\
\hline $30 \%$ & $100 \%$ & $2.40 \mathrm{sec}$ & $2.45 \mathrm{sec}$ & $1.80 \mathrm{sec}$ & $1.85 \mathrm{sec}$ \\
\hline $60 \%$ & $80 \%$ & $1.10 \mathrm{sec}$ & $1.10 \mathrm{sec}$ & $0.90 \mathrm{sec}$ & $0.90 \mathrm{sec}$ \\
\hline $60 \%$ & $100 \%$ & $1.45 \mathrm{sec}$ & $1.45 \mathrm{sec}$ & $1.10 \mathrm{sec}$ & $1.10 \mathrm{sec}$ \\
\hline
\end{tabular}




\section{Other Activities}

In October 1997, the authors attended the 1997 DOE Customer Coordination Meeting (CCM) in Dearborn, Michigan. A project poster was prepared and included in the heavy vehicles poster session. The purpose of the poster session was to provide a forum under which information on current DOE-funded projects in automotive related areas could be shared. 


\section{Conclusions}

The ultimate goal of this work is to develop an overall engine concept with increased efficiency while retaining low emissions. Given this, the authors of this report have tried to relate the technical findings of this project in terms of their individual impact on the engine system as a whole. However, since the focus of the project was divided into two separate technical areas of investigation, it is appropriate that the conclusions are also drawn separately. As such, the conclusions drawn from this work are discussed in the following paragraphs.

\section{Combustion System Conclusions}

A direct injection stratified charge engine concept was demonstrated on a single cylinder of a Deere 8.1L gas engine. Ultra-lean fuel-air equivalence ratio operation was achieved. Engine operation at equivalence ratios approaching those levels needed for throttleless idle operation was demonstrated. Various injector nozzle designs, as well as two different piston geometries were tested. The best operating results were achieved using a DISC approach consisting of a divided bowl piston shape along with a large single-hole injector nozzle. The reason for the success of this combination, relative to the others investigated, is believed to be that a highly penetrating fuel jet was required in order to defeat the in-cylinder air motion and locate most of the fuel within the small combustion bowl for ignition by the spark plug. Part-load efficiency increases relative to the traditional homogeneous charge throttled approach were demonstrated. However, exhaust emissions with the DISC approach have thus far proven to be quite high. Based on the results of the nozzle and combustion chamber tests, it is believed that a DISC approach which exploits the in-cylinder air motion rather than attempting to defeat it may produce more favorable results, both in terms of emissions and efficiency. In summary, the results obtained from the DISC concept thus far have been encouraging, but more development of this concept will be required in order to make this part of a viable engine system.

\section{Turbocharger Subsystem Conclusions}

Two different turbocharger subsystems, a modified wastegated turbocharger and a VGT, were evaluated on the engine in both steady-state and step transient conditions. Both of the turbocharger subsystems performed well, and either would likely be adequate for use on the final engine concept. Both of the subsystems performed equal to or better than the production wastegated turbocharger in the areas of efficiency, transient response, and low level boost controllability. In summary, the performance of the two concepts at low engine speeds was essentially equal, i.e., slightly faster boost response time was achieved using the wastegated turbocharger, but higher boost pressures at low speeds and hence improved low end torque curve characteristics could be achieved with the VNT40. However, at higher engine speeds the VNT40 showed superior performance to the wastegated turbocharger in all respects. Significant increases in engine efficiency, coupled with increases in boost response, and equal or better low level boost control capability was demonstrated with the VNT40. Although Allied Signal would not comment on the production cost of the VNT40 relative to the production turbocharger, SwRI will recommend that this, or another suitable VGT, be investigated in near-term technology programs as well. 


\section{Recommendations for Future Study}

The organization of the work on this project was chosen such that it provided several building blocks needed to further the development of medium- and heavy-duty natural gas engines. As such, the opportunities and need for continuation of this work were planned from the beginning of this project. The next step in the progression of this work was originally planned as an integration and optimization of technologies developed as part of this project into an overall engine system which had full capabilities. The authors believe that this remains a logical and worthwhile plan to move forward with the technologies evaluated and developed. However, prior to an effort to integrate the technologies, as was mentioned in the "Conclusion" section of this report, further standalone development and optimization of the DISC concept is needed.

Among the possible modifications to the DISC concept, an investigation into locating the injector and spark plug within close vicinity of one another, near the center of the combustion chamber, may enable utilization of swirl for maintaining the fuel near the spark plug. This approach may also enable leaner operation at high load conditions using a leaner premixed charge coupled with a late injection and hence a richer mixture at the spark plug.

Upon further development of the DISC concept, the combustion and turbocharging technologies from the project should be combined on the engine. The DISC concept should be applied to the complete engine and the engine control system should be developed to accommodate the full operating map of the engine including transitions between the combustion modes. Engine controller development should also be done to address transient conditions with an emphasis on transitioning between combustion modes.

Testing of the final engine concept in the engine test laboratory should be completed in steady-state as well as transient conditions in order to quantify the performance of the engine versus the baseline data. Steadystate as well as FTP cycle efficiency and emissions data should be collected and directly compared to the baseline data. Ultimately, assuming the final engine concept is shown to be superior to the baseline engine in the laboratory, the concept should be tested in a vehicle demonstration environment such that driving cycle fuel consumption and driveability assessments can be made. 


\section{REPORT DOCUMENTATION PAGE}

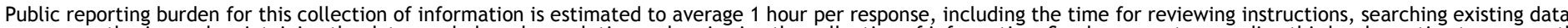

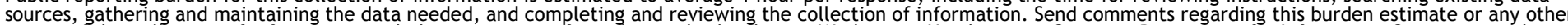

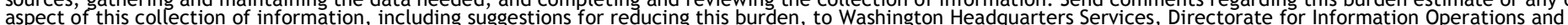

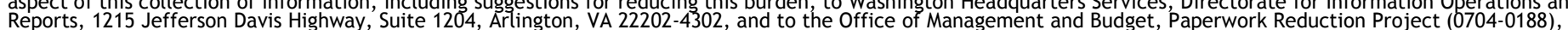
Washington, DC 20503.

\begin{tabular}{|l|l|l}
\hline 1. AGENCY USE ONLY (Leave blank) & $\begin{array}{l}\text { 2. REPORT DATE } \\
\text { February 2000 }\end{array}$ & $\begin{array}{l}\text { 3. REPORT TYPE AND DATES COVERED } \\
\text { Subcontract Report }\end{array}$ \\
\hline
\end{tabular}

4. TITLE AND SUBTITLE

Development of the Next Generation Medium-Duty Natural Gas Engine

6. FUNDING NUMBERS

C: $\mathrm{YCl}-8-17074-01$

TA:FU903110

6. AUTHOR(S)

Daniel J. Podnar and John T. Kubesh

7. PERFORMING ORGANIZATION NAME(S) AND ADDRESS(ES)

Southwest Research Institute

8. PERFORMING ORGANIZATION

REPORT NUMBER

6220 Culebra Road

San Antonio, Texas 78238-5166

9. SPONSORING/MONITORING AGENCY NAME(S) AND ADDRESS(ES)

National Renewable Energy Laboratory

1617 Cole Blvd.

Golden, CO 80401-3393
10. SPONSORING/MONITORING AGENCY REPORT NUMBER

NREL/SR-540-27503

\section{SUPPLEMENTARY NOTES}

NREL Technical Monitor: Keith Vertin

12a. DISTRIBUTION/AVAILABILITY STATEMENT

National Technical Information Service

12b. DISTRIBUTION CODE

U.S. Department of Commerce

5285 Port Royal Road

Springfield, VA 22161

13. ABSTRACT (Maximum 200 words)

This report summarizes the work done under this subcontract in the areas of System Design, System Fabrication, and Experimental Program. The report contains the details of the engine development process for achieving throttleless stratified charge spark ignition (SI) engine operation as well as advanced turbocharging strategies. Engine test results showing the potential of the direct-injection stratified charge combustion strategy for increasing part-load engine efficiency on a John Deere 8.1-liter natural gas engine are also included in this report. In addition, steady state and step transient engine data are presented that quantify the performance of a variable geometry turbocharger (VGT) as well as a modified waste-gated turbocharger on the engine. The benefits of the technologies investigated during this project will be realized in the form of increased drive-cycle efficiency to diesel-like levels, while retaining the low emissions characteristics of a lean-burn natural gas engine.

14. SUBJECT TERMS

natural gas engine; medium-duty engine; engine efficiency

15. NUMBER OF PAGES

17. SECURITY CLASSIFICATION

OF REPORT

unclassified
18. SECURITY CLASSIFICATION

OF THIS PAGE unclassified
19. SECURITY CLASSIFICATION OF ABSTRACT unclassified
20. LIMITATION OF ABSTRACT

UL

NSN 7540-01-280-5500

Standard Form 298 (Rev. 2-89) 